\title{
Price cycles and synchronization in South America
}

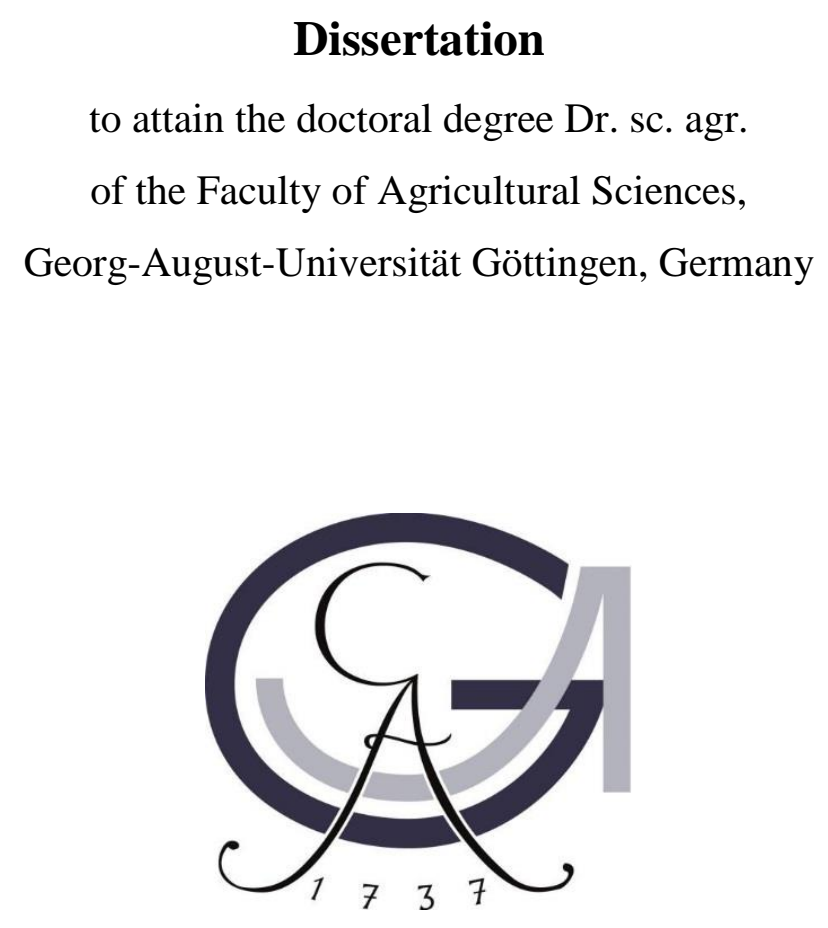

Submitted by

Astrid Fliessbach

born in Concepción, Chile

Göttingen, December 2019 
1. Referee: Prof. Dr. Stephan von Cramon-Taubadel

2. Referee: Prof. Dr. Rico Ihle

3. Referee: Prof. Dr. Bernhard Brümmer

Date of oral examination: 05.02.2020 


\section{Summary}

Prices of agricultural products often vary in relatively stable recurring patterns around their long-run trends. These variations translate into fluctuations of selling prices as well as farm revenues. We provide an overview of the current literature on agricultural price cycles. Using a transparent and reproducible structural model selection process and the Kalman filter, we select optimal models and estimate the cyclic patterns of pig and cattle prices for Brazil, Chile and Uruguay. Durations of cycles in pig and cattle prices is found to respectively be about three years and seven years. These durations are in line with literature and the biological limitations of livestock production. This knowledge can inform producers with forecasts on price developments in the short run. It is useful for guiding policy makers on the timing of policy interventions for influencing the duration or the amplitudes of cycles.

The price spikes in many agricultural commodities experienced simultaneously at the global scale in 2007/2008 have substantially increased the interest in the phenomenon of synchronized movements of agricultural prices. Nevertheless, agricultural economics literature has scarcely devoted attention to the measurement of such synchronization. We fill this gap by measuring various aspects of synchronization between the cyclical components of pig and cattle prices of three Latin American countries for a period of almost 30 years using the concordance index methodology. We also assess potentially temporally varying stability, symmetry and permanence of synchronization. Synchronization between pairs of pig or cattle price cycles is found to be of moderate level: prices moving into the same direction during about two thirds of the observed periods. Synchronization appears to be fairly instable between the price cycles of one commodity across countries as well as across commodities within one country. The instabilities in synchronization tend to be asymmetric. These findings indicate that governments would profit from expanding their institutional efforts for monitoring agricultural and food prices. 


\section{Acknowledgment}

Undertaking this $\mathrm{PhD}$ has been a truly life-changing experience and it would not have been possible to do without the support and guidance that I received from many people.

I would like to express my special appreciation and thanks to my advisor Professor Dr. Stephan von Cramon-Taubadel, who gave me the opportunity to develop my doctoral research at his chair. He has been a tremendous mentor for me, allowing me to grow as a researcher, always had an open door for questions and advice, and gave me the necessary time and confidence to develop this dissertation. His advice on my research as well as on my career has been invaluable.

I am especially indebted to Professor Dr. Rico Ihle for his invaluable research support and academic advice. I appreciate all his contributions of time, ideas, knowledge and structure to make my $\mathrm{PhD}$ experience productive and stimulating. The joy and enthusiasm he possesses for research issues was contagious and motivational for me, even during tough times in the $\mathrm{PhD}$. ¿Querido Rico, no tengo palabras para agradecer tu apoyo!

I would also thank to Dr. Carsten Holst for his support, good advice and enriching discussion. I have been lucky enough to have a chance to spend a few years of my life with the chair and department members, sharing beautiful moments and interesting conversations. Antje fué un placer compartir tantas emociones contigo, gracias.

I gratefully acknowledge the funding received to attend conferences, provided from Göttingen International and the Family Service Office at the Georg-August-Universität Göttingen. I am also grateful to the funding received through the Göttingen Graduate School of Social Sciences at the end phase of my dissertation.

I would like to extend my thanks to the anonymous reviewers and colleagues, for their effort to resurvey my dissertation; Your comments and suggestions were important to strengthen my research.

Nobody has been more important for me in the completion of this project than my family, dear Hubertus, Donata, Eduardo, Victoria and Octavio. Thank you for your understanding and patience during the countless hours I spent on this dissertation. 


\section{Table of Contents}

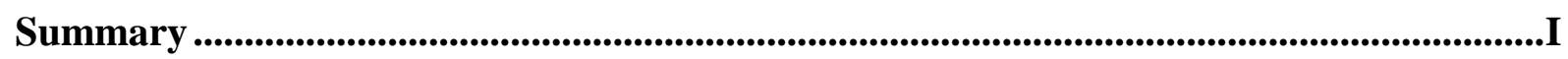

Acknowledgment ...................................................................................................................................... II

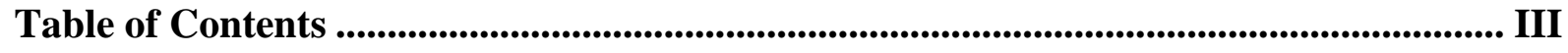

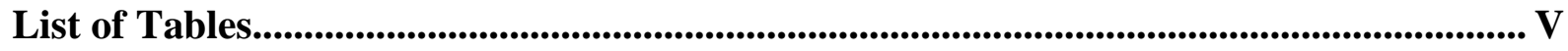

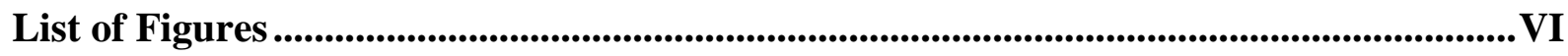

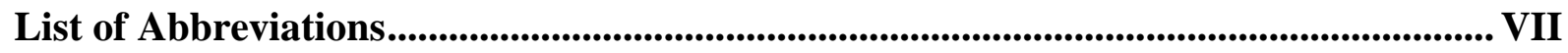

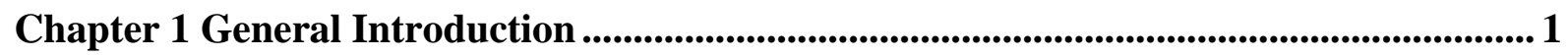

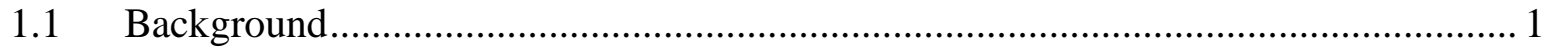

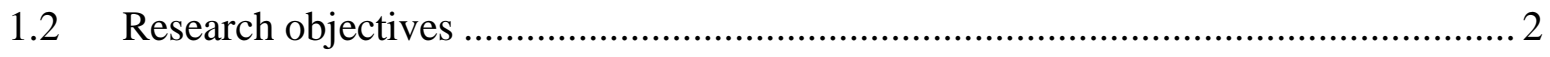

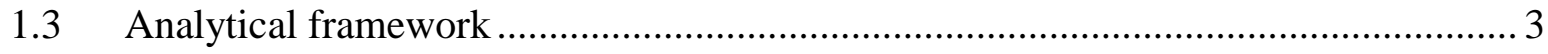

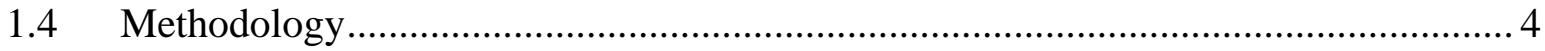

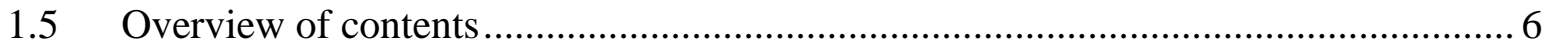

Chapter 2 The pig and cattle sector in Brazil, Chile and Uruguay ........................................8 8

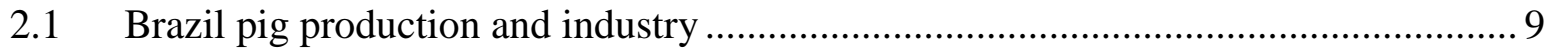

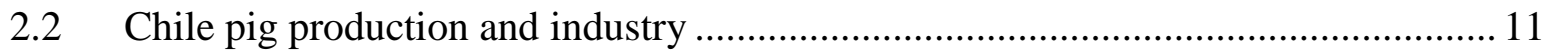

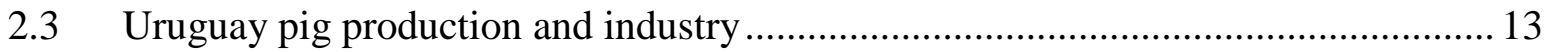

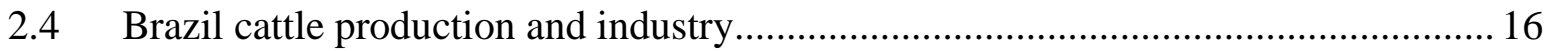

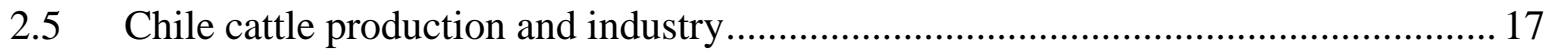

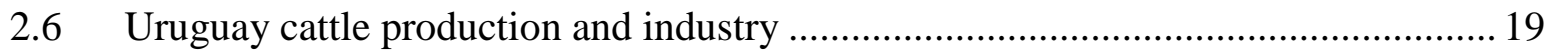

Chapter 3 Cycles in cattle and pig prices in South America ............................................ 22

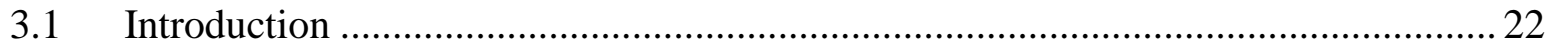

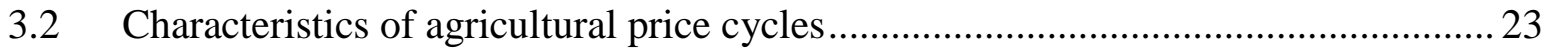

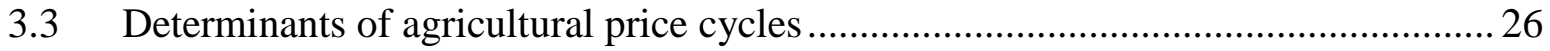

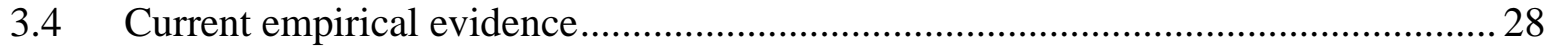

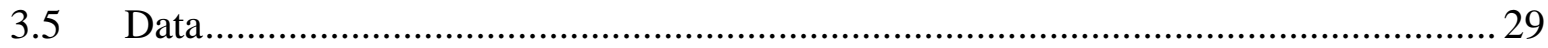

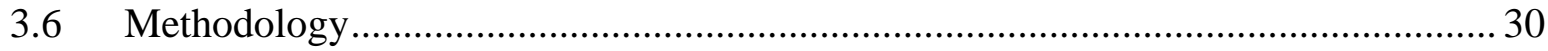

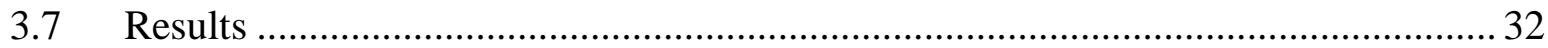

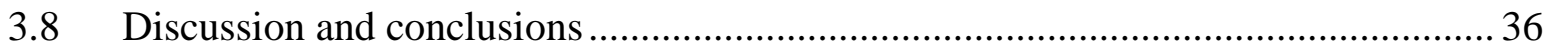

Chapter 4 The synchronization of cycles in pig and cattle prices between Brazil, Chile

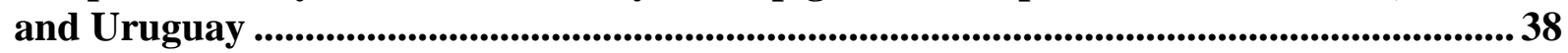

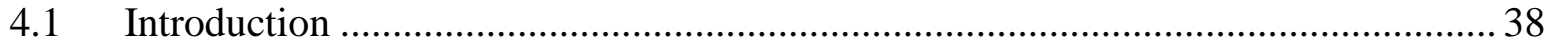

4.2 Overview of price cycle synchronization literature ................................................ 40

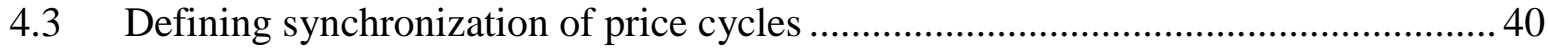




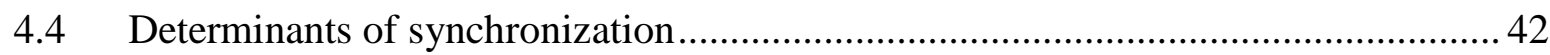

4.4.1 Determinants of synchronized business cycles ................................................. 42

4.4.2 Determinants of synchronized financial cycles ............................................. 43

4.4.3 Determinants of synchronized agricultural prices............................................ 43

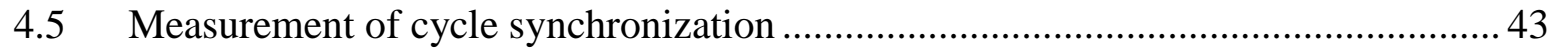

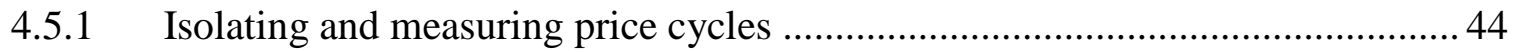

4.5.2 Measuring synchronization by the bivariate concordance index ....................... 44

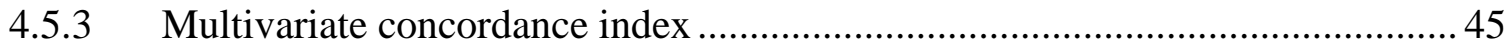

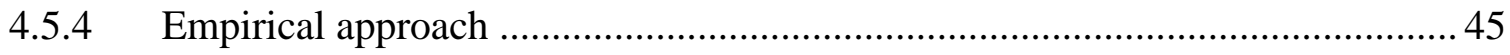

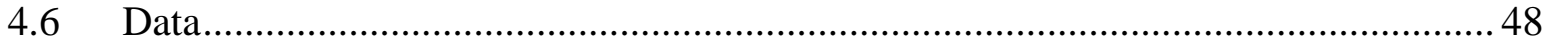

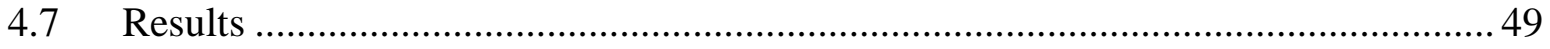

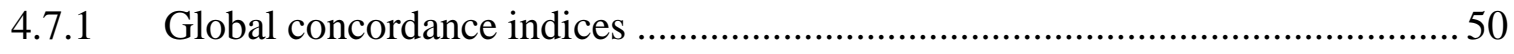

4.7.2 Temporal stability of synchronization........................................................... 51

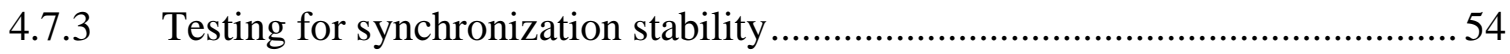

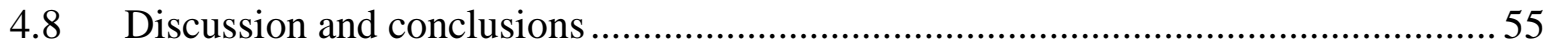

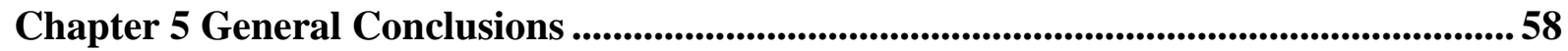

5.1 Research objectives and summary of major findings .......................................... 58

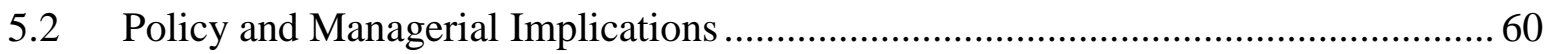

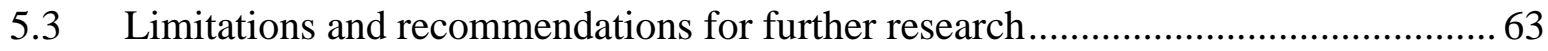

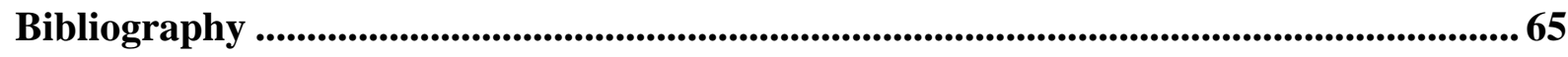

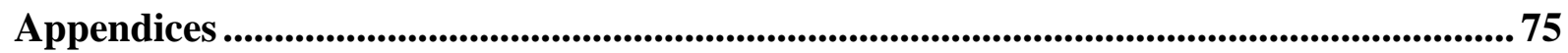

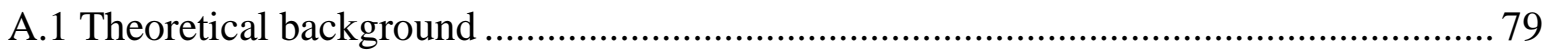

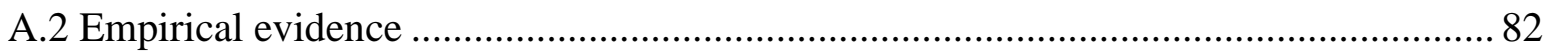

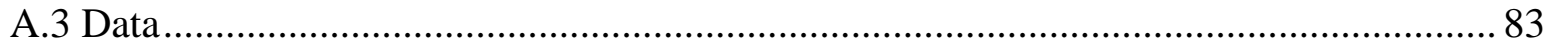

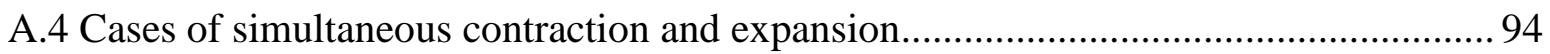

A.5 Cycles filtered with Kalman and Hodrick-Prescott filter ............................................... 94

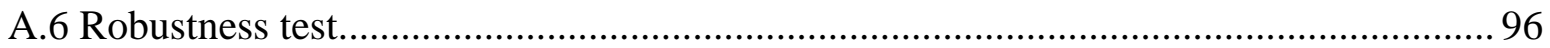

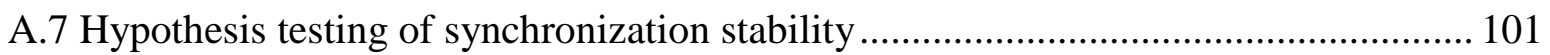

Declaration on the own contribution to the work ...................................................................VIII

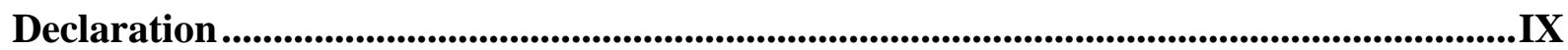




\section{List of Tables}

Table 1 Selected models and equations by country and product ......................................... 33

Table 2 Estimated price cycle parameters for pig and cattle prices by country ...................... 34

Table $3 \mathrm{Bi}$ - and trivariate concordance indices of cycle synchronization............................... 51

Table 4 Deviation between global and rolling window concordance indices ..........................52

Table 5 Rolling window concordance index periods above and below the global concordance

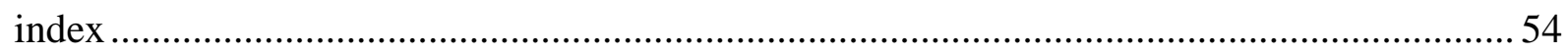

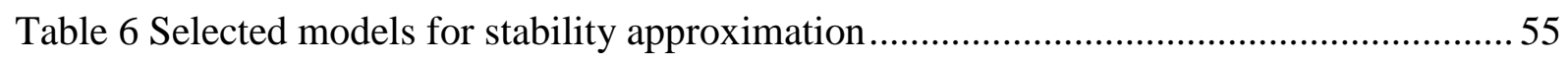

Table A. 1 Per capita consumption of meat 2016 selected LAC countries, USA and world... 75

Table A. 2 Pig and cattle country production, consumption, exports and imports in 2017 ..... 75

Table A. 3 Summary of pig and cattle production chain in Brazil, Chile and Uruguay .......... 76

Table A. 4 Price cycle lengths and used methodology by commodity, country and period .... 82

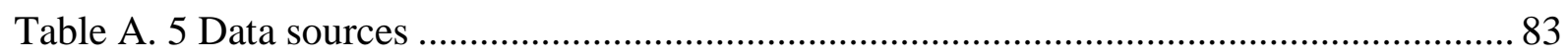

Table A. 6 Descriptive statistics of analyzed producer prices for pig and cattle by country ... 85

Table A. 7 Calculated models with the corresponding selection criteria............................... 87

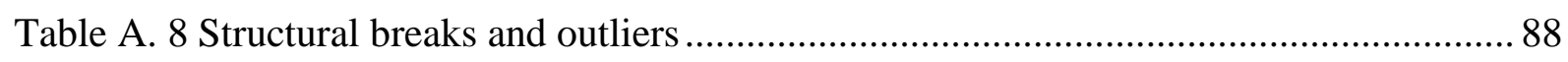

Table A. 9 Literature review of papers analyzing synchronization ...................................... 89

Table A. 10 Descriptive statistics of analysed producer prices for pig and cattle by country 100

Table A. 11 Best model selected and stable or instable hypothesis testing 101 


\section{List of Figures}

Figure 1 Map of Brazil with regions and states .............................................................. 11

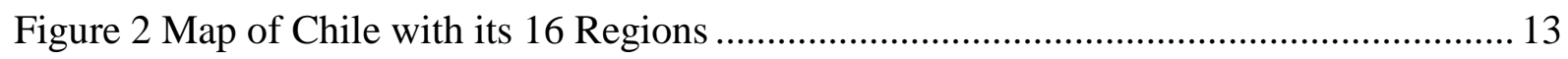

Figure 3 Map of Uruguay with its 19 departments ........................................................ 15

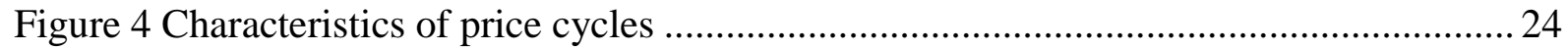

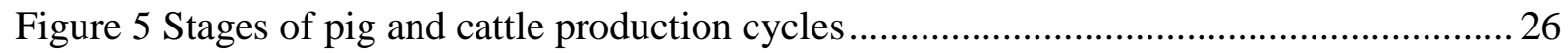

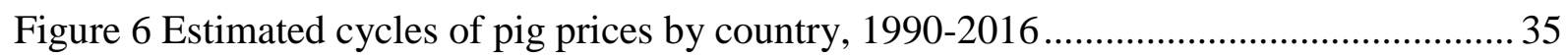

Figure 7 Estimated cycles of cattle prices by country, 1990-2016 ....................................... 36

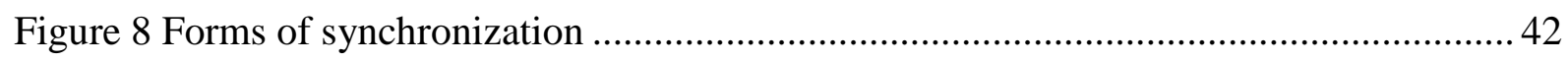

Figure 9 Cycles in pig prices in Brazil, Chile and Uruguay .............................................. 49

Figure 10 Cycles in cattle prices in Brazil, Chile and Uruguay ............................................50

Figure 11 Global vs. rolling window concordance index estimates .....................................53

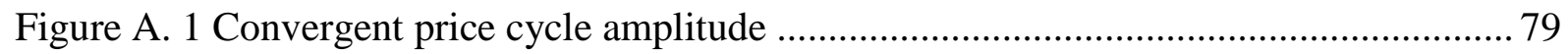

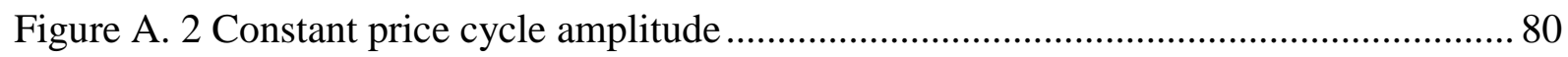

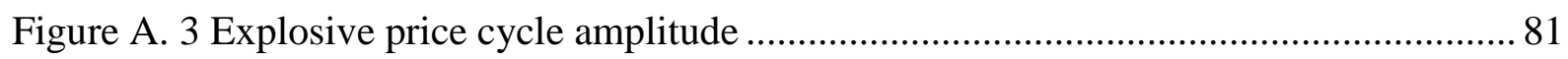

Figure A. 4 Annual minima and maxima of indexed pig price by country, 1976-2016 .......... 86

Figure A. 5 Annual minima and maxima of indexed cattle prices by country, 1976-2016 ..... 86

Figure A. 6 Kalman filter pig cycle in Brazil, Chile and Uruguay ......................................... 94

Figure A. 7 Kalman filter cattle cycle in Brazil, Chile and Uruguay ..................................... 95

Figure A. 8 Hodrick-Prescott filter pig cycle in Brazil, Chile and Uruguay.......................... 95

Figure A. 9 Hodrick-Prescott filter cattle cycle in Brazil, Chile and Uruguay ....................... 96

Figure A. 10 Bivariate global concordance index between countries calculated with the

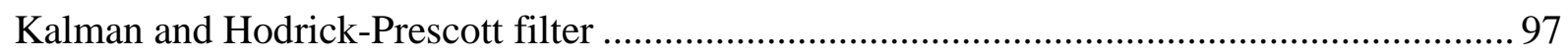

Figure A. 11 Global vs. Rolling window concordance index between Kalman and Hodrick-

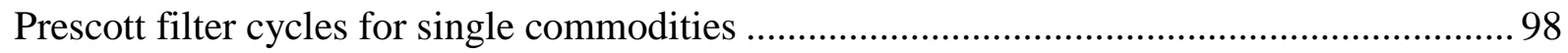

Figure A. 12 Rolling concordance index of the cycle components of all three cattle prices ... 99

Figure A. 13 Rolling concordance index of the cycle components of all three pig prices 99 


\section{List of Abbreviations}

\begin{tabular}{|c|c|}
\hline $\mathrm{ACG}$ & Association of Livestock Consignees Uruguay \\
\hline ASPROCER & Pork Producers Association Chile \\
\hline $\mathrm{BC}$ & Brazil Cattle \\
\hline $\mathrm{BP}$ & Brazil Pig \\
\hline BSE & Bovine spongiform encephalopathy \\
\hline $\mathrm{CC}$ & Chile Cattle \\
\hline CIAT & International Center for Tropical Agriculture \\
\hline $\mathrm{CP}$ & Chile Pig \\
\hline CPI & Common price index \\
\hline $\mathrm{CV}$ & Coefficient of variation \\
\hline ECLAC & Economic Commission for Latin America and the Caribbean \\
\hline ECM & Error Correction Model \\
\hline EMBRAPA & Brazilian Agricultural Research Company \\
\hline ENSO & El Niño Southern Oscillation \\
\hline EU & European Union \\
\hline FAO & Food and Agriculture Organization of the United Nations \\
\hline FDI & Foreign direct investment \\
\hline FMD & Foot-and-Mouth Disease \\
\hline IFAD & International Fund for Agricultural Development \\
\hline IICA & Inter-American Institute for Cooperation on Agriculture \\
\hline INAC & National meat institute Uruguay \\
\hline INE & National Institute of Statistic Chile \\
\hline IPEA & Institute for Applied Economic Research Brazil \\
\hline LAC & Latin American Countries \\
\hline MAGYP & Ministry of Agriculture, Livestock and Fisheries Argentina \\
\hline MAPA & Ministry of Agriculture of Brazil \\
\hline MGAP & Ministry of Agriculture Livestock and Fisheries Uruguay \\
\hline MSE & Mean Square Error \\
\hline ODEPA & Agriculture policy and research bureau Chile \\
\hline OECD & Organization for Economic Co-operation and Development \\
\hline OIE & Office of International Animal Health \\
\hline OPYPA & Office of Agricultural Programming and Policy Uruguay \\
\hline PIC & Pig Improvement Company® \\
\hline ProChile & Chilean Export Promotion Bureau \\
\hline PYMES & Small and medium enterprises \\
\hline SPNS & Strong perfect negative synchronization \\
\hline SPPS & Strong perfect positive synchronization \\
\hline SNS & Strong non-synchronization \\
\hline UC & Uruguay Cattle \\
\hline UK & United Kingdom \\
\hline UP & Uruguay Pig \\
\hline USA & United States of America \\
\hline VAR & Vector Autoregressive Models \\
\hline WFP & World Food Programme \\
\hline
\end{tabular}


For my family 


\section{Chapter 1 General Introduction}

\subsection{Background}

Price fluctuations around a long run trend of a period longer than one year are named price cycles. Depending on the phase in which a cycle is, it can create costs for consumers, producers and governments that face liquidity problems, as is often the case in less developed countries (Jayasuriya et al., 2012). FAO et al. (2011) and The Economist (2007) mentioned the end of a phase of stable and gradually declining real food prices, followed by a phase of increasing prices. An era of increasing food prices and two synchronized price peaks in international food markets in recent years (2007/08 and 2010/11) have highlighted the threat to world food security (Jayasuriya et al., 2012; FAO et al., 2011). In addition to the above, the latest publications focusing on synchronization originating from shocks came to the conclusions that price synchronization is a threat to food security (Anderson et al., 2019; Tigchelaar et al., 2018; Mehrabi and Ramankutty, 2019).

Furthermore, production of meat, eggs, and dairy products has to increase substantially by 2050 , as a result of predicted rising demand for animal protein (Barrero et al., 2017). The FAO (2011) forecast a $58 \%$ in bovine and $37 \%$ in pig worldwide meat consumption increase between 2010 and 2050, based on world population growth to between nine to ten billion inhabitants. The major increase for animal protein will come from developing countries, with meat consumption forecasted to increase by $100 \%$ in bovine and $58 \%$ in pig. Much of the demand growth results not only from an increasing population, but also from increasing urbanization, disposable incomes rises (Barrero et al., 2017) and globalization (Fava et al., 2016).

Livestock production has grown mainly in Latin America: during the last twenty years, beef production has increased by $33 \%$ and pork by $111 \%$. This growth has been driven by expansions of the pig and cattle sectors, and by technological innovation in all livestock sectors (OECD and FAO, 2019a). Nowadays, livestock production has to contend with rapid intensification, diseases, land pressure, changing climate conditions, food chain dynamics (FAO, 2013) and changing demand with higher environmental and animal welfare awareness (Fava et al., 2016). Latin America currently produces more than $25 \%$ of the world's beef and over $20 \%$ of its poultry. The focus of meat production in the Americas is increasingly shifting toward South 
America, Brazil in particular. Latin America beef exports have doubled, while exports of pork and poultry by Brazil and Chile have quadrupled over the last decade (Barrero et al., 2017).

With regard to world meat production, the main producers of beef are the United States, Brazil, China, Argentina and Australia. In the case of pork, the five main countries with the largest quantities produced are China, the USA, Germany, Spain and Brazil (FAO, 2019). South America has significant potential for livestock production, due to favorable climatic conditions and availability of agricultural land.

Assessments on the future behaviors of agricultural prices have always been important tasks for economists to reduce risks in food security, and influence strategies of farmers, governments and agribusiness industries. Efforts to predict agriculture prices and understand movements first led to price cycle analysis in 1928 by Hanau, in what was known as the "pork cycle" by agriculture economists, the "Schweinezyklus" in German. Price cycles are recursive price fluctuations longer than one year and are a result of the interaction of supply and demand. The supply side is characterized in these cases by delayed supply responses due to biological constraints. Price cycles have a statistic history that can be modelled and used for forecasting purposes.

In a more globalized and digitalized world, price cycles and their synchronization can be influenced by international trade in goods and services, international trade in financial assets, and direct linkages between production sectors of different countries (Calderón, 2007). HomerDixon et al. (2015) point out that synchronization has changed. They observed an interrelated synchronization between different systems, with global scope and faster development. In this sense, we seek to expand the literature on price cycles and the synchronization of pig and cattle prices in South America, specifically in Brazil, Chile and Uruguay, to serve as a guide for future studies and decision making at the political and business level.

\subsection{Research objectives}

Being that South America is a potentially important player in the meat sector, the general objective of this study is to address gaps in the literature concerning price cycles in the pig and cattle sectors, and their synchronization in South America.

To achieve the general objective set forth, we have developed the following specific goals:

- Measure price cycles in the context of Brazil, Chile and Uruguay

- Characterize these prices cycles regarding the cycle duration and amplitude 
- Quantify the price cycle synchronization of cattle and pig prices

- Test synchronization stability between the countries

\subsection{Analytical framework}

Agricultural markets are characterized by regular price fluctuations of various durations, possibly caused by weather, technology or other supply-relevant shocks, in combination with an inelastic demand for food. Economically, the concept of price cycles refers in agriculture to periodic price fluctuations longer than one year. One theoretical explanation of such a regular price patterns is the delayed reaction of producers in generating agricultural supplies due to biological production constrains, which can be highly relevant in livestock production. For livestock producers, this delay is determined by the duration of gestation, nursing and fattening, in turn affecting producers' ability to adjust supplied quantities in response to price changes. The model assumes that farmers base their next year's supply only on the price of the previous year, and they assume that prices in the next year will be the same as last year (naïve price expectations). However, the above rarely applies to farmers today. Farmers have adaptive and rational expectations, due to a learning process and higher information availability. The pork cycle is one example of such regular fluctuations. It refers to the regular pattern in pork slaughter prices of an approximate duration of three to four years, observed and analyzed first by Hanau (1928). Similarly, the cattle cycle corresponds to cyclical patterns in cattle slaughter prices of six to ten years in South America and ten years in US (Mundlak and Huang, 1996).

According to Koester and El-Agraa (2011), there are significant regional fluctuations in food supply affecting food security. Food security would not be threatened if markets functioned perfectly with a constant world supply, and markets are imperfectly integrated due to high transaction costs and policies that minimize trade between regions. Due to the reduction of trade barriers, market liberalization, international trade, market competition and globalization, it is interesting to see if such price cycles exist at the domestic level and how they behave in terms of their synchronization both between countries and within one country.

Synchronization of price cycles refers to simultaneous cycle variations in the same direction, through troughs or peaks of price adjustments of homogenous commodities. These mutual fluctuations can be the result of supply and demand shocks that affect several prices simultaneously and/or from spill-over effects from one market to another (Labys et al., 1999). One explanation as to why prices move together between markets is the theory of the law of one price. The law of one price states that the prices of an identical commodity or asset traded in different geographic markets under competitive market conditions are uniform. The law of 
one price results from profit-seeking behavior of food marketing firms and traders (Kohls and Uhl, 1990).

\subsection{Methodology}

This study analyses the characteristics of price cycles and their synchronization in Brazil, Chile and Uruguay, focusing on producer prices. In order to make price cycles measurable, we define a price cycle econometrically as the observed periodic deviation from the long-run trend. One realization of a cycle is defined from start to finish between troughs (the minimum of a negative deviation). In-between, the cycle shows one peak (a maximum deviation from the long-run trend). We used producer prices obtained from different domestic organizations: The Institute for Applied Economic Research (IPEA) in Brazil; the Office of Agricultural Studies and Policies (ODEPA) in Chile; and the National Meat Institute (INAC) in Uruguay. We analyzed prices based on nominal, monthly farm-gate selling prices of live animals. This raw data is transformed into real prices in national currency using domestic CPIs for the common base of January 2001.

In order to extract, measure and characterize price cycles regarding cycle duration and amplitude, we use a transparent and reproducible structural model selection process and the Kalman filter (Kalman, 1960), which takes full advantage of information available in a time series $^{1}$ and allows work with non-stationary time series. The Kalman filter is a time-varying stochastic process that decomposes times series into different parts such as a smoothed longrun trend, cycles, seasonal and irregular components. The estimation of the trend and the cyclical components is based on a state-space model with time-varying parameters, which results in smooth non-parametric estimates.

Hence, Chapter 3, analyses pig and cattle prices in the period between 1990/01 and 2016/12 for Brazil, 1976/01 and 2016/12 for Chile. For Uruguay, cattle prices were available between 1984/01 and 2016/12, however Uruguayan pig prices were only available from 1984/01 to 2008/12. The real prices are calculated as indices in order to better visualize the relative development of the different national prices at a common level (due to the data being in national currencies, real prices are in different units and hardly comparable). This index ${ }^{2}$ represents the percentage deviation of the prices in each month relative to a reference, which is the mean of each price series in national currency. The indices are calculated by dividing the real price (base

\footnotetext{
${ }^{1}$ Structural time series models are formulated in terms of unobserved components that have a direct interpretation. The statistical treatment of such models is based on the state space form (Carvalho and Harvey, 2005, pp. 276). ${ }^{2}$ price index $=\frac{\text { real price }}{\text { mean }}-1$
} 
year 2001/1) by the mean of the corresponding series and subtracting one unit. In order to analyse price cycles, it is necessary to make them visible, disaggregating the price series by trend, seasonality and cycle, allowing for analysis of these different unobserved components.

For the measurement and characterization of synchronization in Chapter 4, the data used is the same as in Chapter 3, but the period is reduced to between 1990/01 and 2016/12 for all countries in the study, with the exception of Uruguay pig prices to between 1990/01 and 2008/12. After extracting the cycle with the Kalman filter, synchronization is quantified through the bivariate and trivariate global concordance index, a methodology developed by Harding and Pagan (2002; 2006). This methodology is applied in order to describe the behavior of price cycle synchronization, measuring the fraction of time series are simultaneously in the same phase of their respective cycles (contraction or expansion).

We also developed a rolling window concordance index. The rolling window concordance index has the advantage of showing the development of synchronization over time in a fixed time window: the global concordance index only provides one value of synchronization over the total observation period. We proceed with the analysis measuring selected aspects of synchronization stability between two or more cycles based on the Kalman filter extractions. In particular, we provide evidence on the magnitude of instable synchronization, for which we also test, as well as on the duration of phases of temporally higher and lower synchronization than the global aggregate.

We assess stability of synchronization using a mean square error (MSE) type measure calculated between the rolling window indices and the global index. MSE measures how close the bivariate rolling window concordance index is to the bivariate global concordance index over all observation periods. For every observation period, the vertical distance between the estimate of the bivariate rolling window concordance index and the corresponding estimate of the bivariate global concordance index is squared. All squared deviations are added up and divided by the number of total periods. The smaller the resulting measure of MSE, the more stable the synchronization. In order to characterize the length of the synchronization deviation, deviation between the rolling window concordance index and global concordance index, we count the number of months in which the bivariate rolling window concordance index moves above and below the bivariate global concordance index line.

For testing synchronization stability, we apply $\mathrm{F}$ tests to ascertain whether the rolling window estimates significantly differ from the stable global estimates. That is, to test whether the rolling 
window estimates are nested in the global concordance estimate. We tested the null hypothesis of stable synchronization against the hypothesis of unstable synchronization.

\subsection{Overview of contents}

The remainder of this dissertation consists of four chapters addressing the research gaps and is structured as follows:

Chapter 2 includes a brief background as an introduction to the pig and cattle sectors. It provides an overview to aid understanding of the sector, identifying possible similarities and business relationships between the countries in the study, also including different country production and industry characteristics.

Chapter 3 addresses the first and second objective in this thesis, measuring and characterizing price cycles in Brazil, Chile and Uruguay in the pig and cattle sectors. Therefore, the first part of this chapter defines price cycles characteristics amplitudes, durations, peaks, troughs and possible origins of agricultural price cycles. It also includes a literature review, exhibiting agriculture price cycle durations in other countries and evidencing a literature gap in the agriculture price cycle topic in Latin America. The last part of the chapter concentrates in selecting the most appropriate model, using a structural model selection process and the Kalman filter, giving the main characteristics of the cycles found. A theoretical background, literature, empirical evidence and detailed data sources are included in the appendix.

Chapter 4 addresses the objectives of quantifying price cycle synchronization of cattle and pig prices and testing synchronization stability between and within countries. In this sense, the first part of this chapter concentrates on defining synchronization, followed by a review of relevant existing literature; the main determinants affecting business, financial and agriculture price cycles and methodologies already used to measure synchronization. The measurement of synchronization is done with the global concordance index developed by Harding and Pagan (2002; 2006) in a bivariate and trivariate form, and synchronization stability testing is impemented through $\mathrm{F}$ tests to ascertain whether the rolling window estimates significantly differ from the stable global estimates. The appendix of this section includes cases of simultaneous contraction and expansion, a comparison of cycles filtered by the Kalman and Hodrick Prescott filter (Hodrick and Prescott, 1997), a robustness test and detailed results of the stability hypothesis testing. 
The concluding Chapter 5 summarizes the main findings of the analysis, gives a perspective over policy implications and limitations of the research, with considerations for further research. 


\section{Chapter 2 The pig and cattle sector in Brazil, Chile and Uruguay}

This section intends to describe the structure of the pig and cattle sector in each country of this study, to provide a solid understanding of the productive systems at the farm and industry level, and identify dynamics of the sector and market power of the different actors. A good understanding of the sector and its interrelation is the basis of a good analysis.

In South America, meat constitutes a key ingredient in culinary traditions, where a meal is regarded not only as food consumption, but one of sharing; a family, social and cultural act. Since the beginning of the nineteenth century, South America began to industrialize meat production and export beef. This required the fencing of land and limiting the free passage of livestock. These livestock management practices were utilized extensively until the end of the 20th century. The memory of free and healthy cattle in abundant pastures sparks to this day the imagery of the grill. A community fascinated by fire and yearning for the aromas of a barbecue, purposefully prepared and roasted with all the ceremony that tradition requires (Alvarez, 2014). Meat consumption in South America is high. The leading meat consumer in South America is Argentina (Table A.1 in the appendix) at 87.5 kilograms per head $(\mathrm{kg} / \mathrm{hd})$. Uruguay achieved per capita meat consumption of $80.5 \mathrm{~kg} / \mathrm{hd}$ in 2016 , Brazil consumes $78.4 \mathrm{~kg} / \mathrm{hd}$ of meat and Chile consumption is $64.1 \mathrm{~kg} / \mathrm{hd}$. Consumption of beef is highest in Uruguay, followed by Brazil and Chile. Chile head pork consumption in South America followed by Uruguay and Brazil, for exact consumption details see Table A.1 in the appendix (ECLAC et al., 2017).

In recent years, Brazil has led the world meat market as a result of a set of factors that promoted both public and private activity. One of the key aspects was the significant increase in the Brazilian stock of cattle in the last 50 years. This is mainly due to the expansion of the productive frontier towards the central-west region of the country, in addition to technology adoption in primary production, such as artificial insemination, the development of fattening systems under feedlots, and the use of new forage pastures that provide greater volumes of pastoral production. Additionally, the economic growth of Brazil in the last five years has caused a significant increase in the internal consumption of meat. However, a central problem is that livestock farming generates environmental issues, increasing the emission of greenhouse gases and causing deforestation for forage production and fattening enclosures (Alvarez, 2014). 
In Brazil, the internal market represents more than $80 \%$ of the demand in pork and beef, and therefore guides respective production structures. The prices of meat in Brazil depend more on the strength and weakness of domestic consumption than export performance (Köbrich et al., 2018).

In Chile, the consumption of beef, pork and poultry has increased in recent years. This has made it necessary to fill the national production deficit with imports, which have also been favored through a constant decline in trade barriers and its sanitary status as a foot-and-mouth disease (FMD) free country. The intensive nature of the meat industry, particularly the poultry and pork industries, has caused substantial problems among rural populations where they produce. They generate problems such as water scarcity and pollution of the local environment (Alvarez, 2014). Chile, in regard to fresh and chilled beef, is the main destination country for exports from Paraguay, Brazil and Argentina, representing 77\%, 42\% and 39\% of the volume exported by these countries in 2017, respectively. Uruguayan beef is also received, compromising $11 \%$ of the total Uruguayan export volume in 2017 (Köbrich et al., 2018).

In Uruguay, livestock has accounted for almost $90 \%$ of land use for many years, becoming the most important agricultural activity in the country and generating the highest employment. In 2009, livestock area began to decrease, with shifting percentage composition of inputs associated with changes in livestock feeding strategies, from grazing to feedlots with concentrated feed. Thus, meat production in Uruguay grew at constant rates and its exports quadrupled, both in volume and value, the number of animals increasing $26 \%$ in that period. Since 2008, the industry has sought to expand its plants. In recent years, investment has been channeled into feedlots secure a supply of livestock supplies for slaughter (Alvarez, 2014). In Uruguay, foreign markets purchase about $70 \%$ of production, and therefore it is external prices that have greater effects (Köbrich et al., 2018).

\subsection{Brazil pig production and industry}

Brazil stands out as the fifth largest world producer of pork; whose main destination is the domestic market. It consumes $84 \%$ of the produced pork, exports $16 \%$ of the production and imports less than $1 \%$ of the total domestic production $(3,840,500$ tons), see Table A.2 in the appendix (OECD and FAO, 2019b).

Brazil was declared by The Office of International Animal Health (OIE) in May 2019 free of FMD with vaccinations. The only FMD-free state without vaccinations is Santa Catarina (Silva and Flake, 2018). 
Brazilian pig production is distributed through the whole country, but varies from region to region in terms of the scale of production, technology adoption and production contracts between producers and processing company. Pork production can be divided into industrial and subsistence, with the presence of family producers, employers and businesses (Fava et al., 2016).

The southern region houses $60 \%$ of Brazilian pigs (see Figure 1), $45 \%$ of the producers are integrated $^{3}, 19 \%$ independent $^{4}$, and $37 \%$ in cooperatives. The closed integrated system is characterized by better sanitary control, production efficiency and higher income stability, as slaughterhouses provides producers with animals, fodder and veterinary support (Silva and Flake, 2018). $20 \%$ of pigs are in the southeast, with $82 \%$ of farmers independent, $18 \%$ integrated and no cooperatives. In the mid-west, housing $18 \%$ of pigs, $45 \%$ of producers are independent, $50 \%$ integrated and $5 \%$ in cooperatives. Only $1.7 \%$ of pigs are in the northeast, and $0.3 \%$ in the north, with all farmers here being independent (Fava et al., 2016).

South Brazilian pig production is characterized by a segregation of production at multiple stages in different types of farms; piglet producing units (PPU) are farms that produce piglets, including nurseries; weaned piglets production units (WPPU); nursery, wean to finish (WTF); finishing units (FU) and full cycle (Fava et al., 2016). This tendency towards specialization in the stages of the production process occurs throughout the country, but is more intense among integrated production in the southern region (Ludtke, 2010).

In the southern regions there is an increase in production due to a continual increase in slaughter weights, thanks to the use of high quality genetics, better nutrition and better animal welfare practices (Silva and Flake, 2018).

There are two distinct groups of companies and cooperatives that slaughter and process pork in Brazil: market leaders and organizations operating in regional and local markets. Among the market leaders, strategies focus on gains in scale, brand promotion in processed products and the integration of production. They are large organizations with more than one industrial unit (multiplantas) and international coverage. Most are diversified, also operating in the poultry segment (usually its main product), dairy, beef and processed foods (Ludtke, 2010).

\footnotetext{
${ }^{3}$ Pig producers are an important service provider with specialization in some functions of production activity, primarily raising and fattening pigs, which are owned by the industry. Private industry is the legal owning entity, which provides and manages most of the production factors, safeguarding the animals, which are subsequently property of the industry.

${ }^{4}$ Pig producers who buy inputs for their production and sell pigs to industries without formal contracts. The majority of these producers have a "full cycle" production system, with all production stages (pregnancy, maternity, nursing and finishing) at the same place.
} 


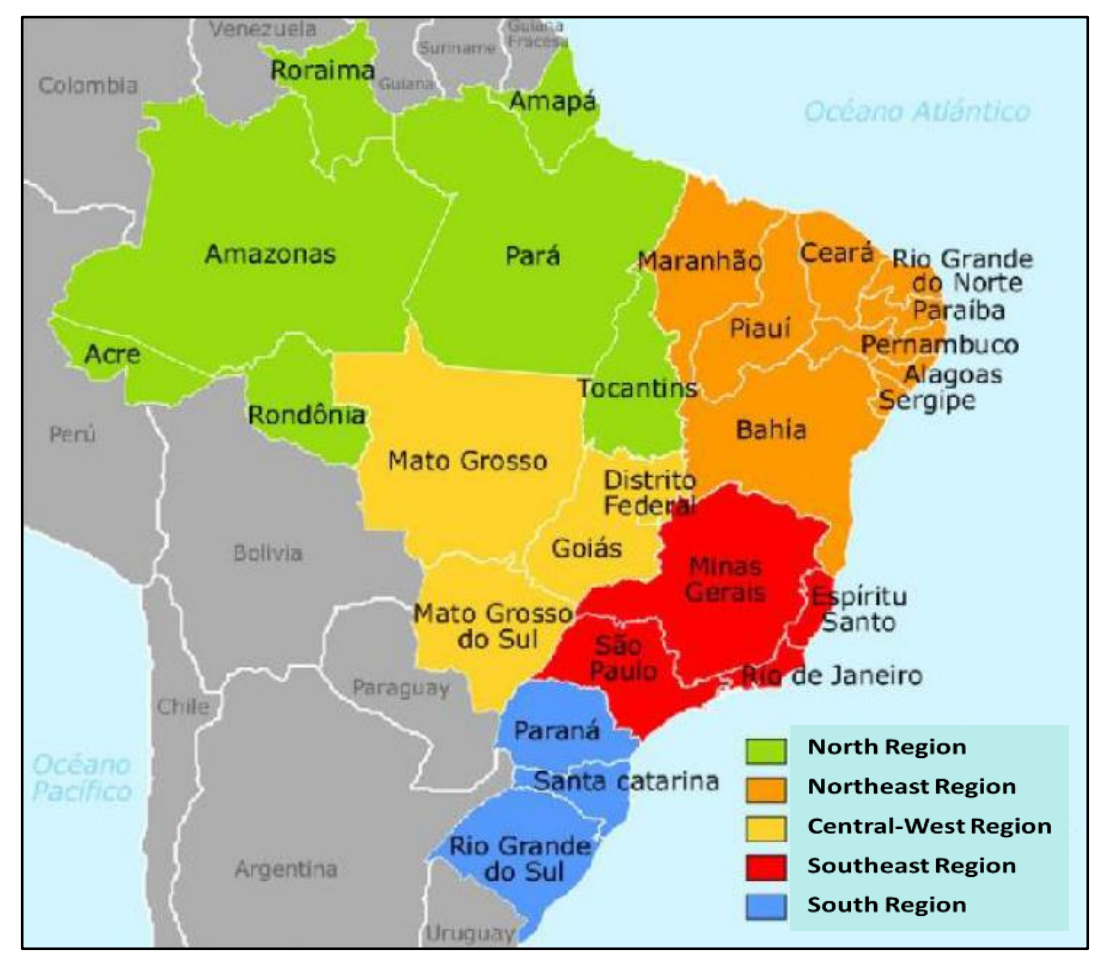

\section{Figure 1 Map of Brazil with regions and states}

Source: Köbrich et al. (2018).

According to Fava et al. (2016) there were 110 slaughterhouses registered in 2015. The top ten slaughter $37 \%$ of Brazilian pigs under the Federal Inspection System. The main slaughter companies in Brazil are BRF, with $28 \%$ of participation, JBS (14\%), Aurora (14\%), Frimesa (5\%), Alibem (5\%) and others (34\%).

\subsection{Chile pig production and industry}

Pork is the second most-produced type of meat in Chile after poultry. It is the sixth largest world exporter of pork according to international rankings, after the European Union, the United States, Canada, Brazil and Hong Kong. The main destinations for Chilean pork were Japan, South Korea, Russia and China (Acuña and Pizarro, 2019). This has been achieved by the existence of a strategy aimed at responding to the individual needs of each market (ProChile, 2013).

Chile's production is not enough to supply the domestic and export market: domestic demand is supplemented with imports. Chile consumes 449,268 tons of domestically produced pork (see Table A.2 in the appendix), equating to $92 \%$ of domestic production, with 162,440 tons exported (33\% of domestic production) and 122,611 tons imported (25\% of domestic production) (OECD and FAO, 2019b). 
The pig industry in Chile has based its development on geographic isolation that has been essential to maintain its biosecurity standards, which are highly valued by Chileans. Due to an open market strategy and economic stability, investments have increased, which have had a positive effect on the quantity and quality of production. In order to meet the requirements of the buyer, there is a highly controlled production process. Chilean pig production has grown due to an increase in efficiency, aggressive marketing campaigns and the transfer of low grain prices to consumers, stimulating the domestic consumption of pork (Hennicke and Sloop, 2005). At the same time, it has managed to develop good coordination between the private sector and the state. This translates into effective programs for disease control and prevention and food safety. However, pork production is not a strategic industry within the agricultural program, nor does it benefit from state subsidies. They are producers that constantly have to reach higher levels of efficiency to achieve profitability (PIC, 2012).

The production of pigs in Chile is characterized as being highly intensive, technologically advanced, vertically integrated in the different links of the chain and concentrated in few actors. The Chilean pig industry is focused on exports, with 64 different destination countries (Acuña and Pizarro, 2019).

The companies associated with ASPROCER (pork producers association) correspond to small, medium and large producers, represents $94 \%$ of national pork production, and has 25 members (ASPROCER, 2019). Five large pork packers control $75 \%$ of pork production in Chile. Approximately 3\% of total pork production comes from small and medium producers. Agrosuper produces $65 \%$ of total production, Friosa $15 \%$ and Lo Valledor $8 \%$. In Chile there is high traceability of pork during the production process to ensure safety, quality and reliability of the meat produced, stemming from high vertical integration in the production process. The main factors that explain the Chilean success in the pig industry are the substantial investments for the incorporation of technology, which improves health and production levels, in addition to the constant opening of export markets through the implementation of free trade agreements (Hennicke and Lopez, 2006).

Pig production in Chile has been geographically concentrated and the number of production centers has reduced over the years. The O'Higgins Region houses $84 \%$ of production (see Figure 2), the Valparaiso and Metropolitan regions 8\%, the Bio-Bio region 4\%, Maule 3\%, La Araucania and Los Lagos 1\%. Production centers have been consolidating, from 74 in 2011 to 43 in 2017 (Acuña and Pizarro, 2019). 


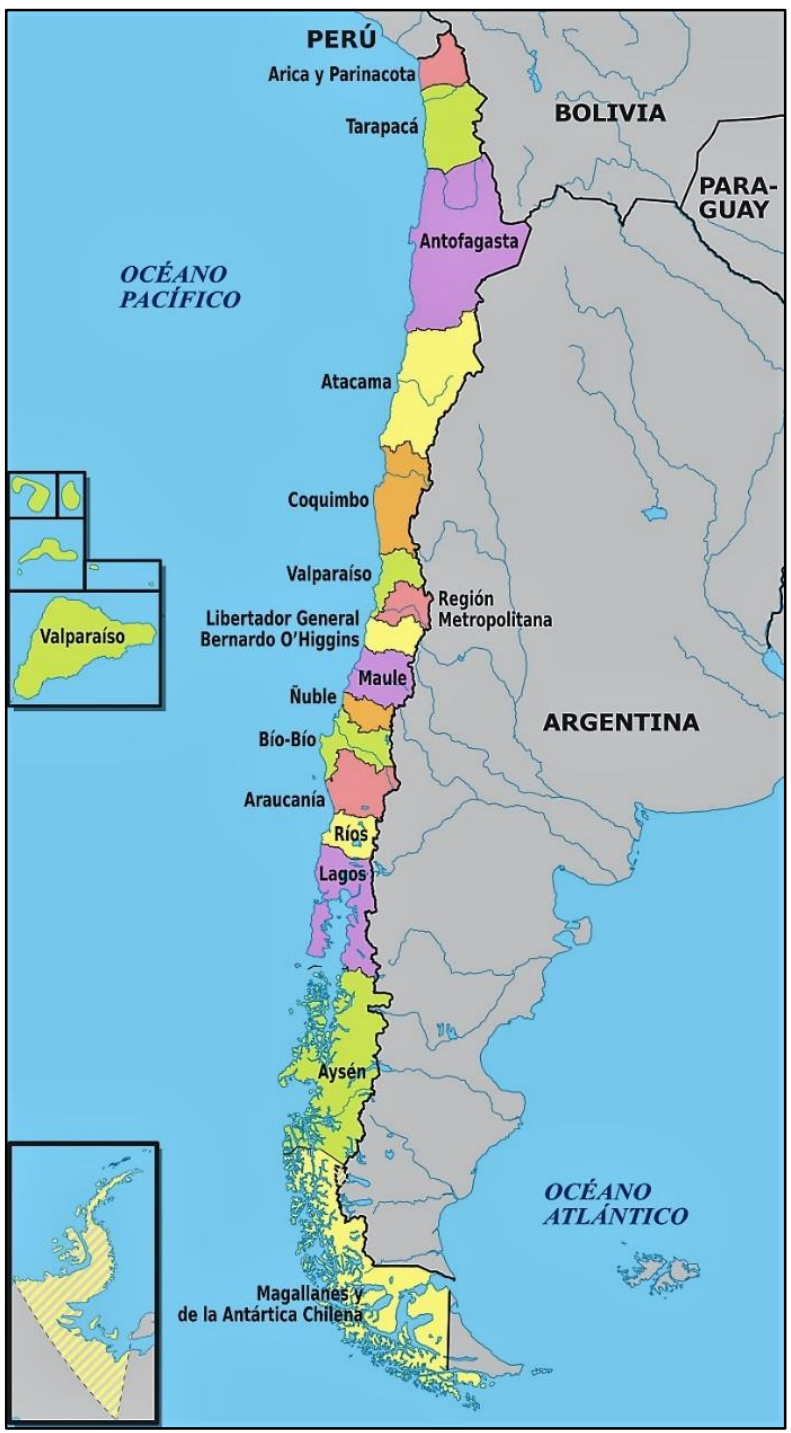

Figure 2 Map of Chile with its 16 Regions

Source. https://mapamundi.online/america/del-sur/chile/ .

Currently there are 141 industrial slaughterhouses, with a high concentration in the VI Region (68\%), due to the presence of Agrosuper, a company that leads national production, with about half of the domestic market. Agrosuper Comercial is responsible for marketing meat through a complete distribution network and 28 terminals in the main cities of the country, while Cecinas Super is one of the largest national producers of these products, with a plant in the Metropolitan Region. The Lo Valledor Holding Company (AASA) company, although not as important as a primary pig producer, is an important slaughterhouse through its Lo Valledor plant (ODEPA, 2005).

\subsection{Uruguay pig production and industry}

Uruguay's pig production is not enough to supply the domestic demand. Uruguay imports pork meat and fat for further processing. The raw material with which the pig meat industry is 
supplied is mostly of foreign origin (61\%), mainly from Brazil and Chile, while national production represents $39 \%$ of the raw materials used by the industry. Uruguay does not have any type of sanitary restriction in regard to pig production. The Uruguayan pork trade is primarily domestic and is mainly sold in butchers and supermarkets (Uruguay XXI, 2011).

94\% of Uruguayan pork imports in 2018 originated from Brazil. In addition, Uruguay imported pig meat from Germany, Spain, Chile, Denmark, Norway, Canada and Belgium, which together accounted for $6 \%$ of the remaining volume. Pork consumption in Uruguay has increased in recent years, at the same time domestic production has decreased and imports have risen (Gorga, 2018).

The low production of pigs in Uruguay corresponds to the costs of feed: the production process makes it more expensive. Another important aspect to note is that less and less beef is used for the production of sausages and more pork is used in the sausage industry. Products such as mortadella, in which some beef was mixed before, today is only made with pork. Currently, both imported pork and Uruguayan products are the same price. It is for this reason that the sausage industry prefers to import frozen products, since they save labor costs (ProChile, 2013). Uruguay consist of 19 regions called departments as shown in Figure 3. The establishments with pigs are mostly located in the central-south, west and east areas of the country. $16 \%$ of the farms are concentrated in the department of Canelones, $11 \%$ in Colonia, 9\% in Rocha and 9\% in San José, which together represent $45 \%$ of the total farms with pigs. The center-south and west coast are associated with the agricultural, horticultural and dairy sectors, while the east coast is associated with extensive livestock production and the rice industry (Bell et al., 2014). There is a process aimed at concentration and increasing the scale of pig producers, led by large companies with high capital investment in inputs, genetics and facilities (Bell et al., 2014). 35\% of pig stocks are found in seven farms of more than 500 animals, $24 \%$ of farms have between 50 and 499 pigs and 34\% of farms only handled between 5 and 49 animals in 2017 (Gorga, 2018).

There are three types of clearly defined establishments: breeding, wintering and full cycle. The 2006 swine survey showed a percentage increase in commercial breeders (77\% of the total) and decreasing number of full-cycle and winter establishments (19\% and $4 \%$ of the total) (Bell et al., 2014).

Regarding the type of housing, $36 \%$ of the farms have total or partial confinement of the animals, $44 \%$ in the field and $20 \%$ a combination of both systems. The trend is that breeding 
animals are housed in the field while fattening animals are confined to higher intensity facilities. Farms with confinement house 39\% of the Uruguayan pig population (Gorga, 2018).

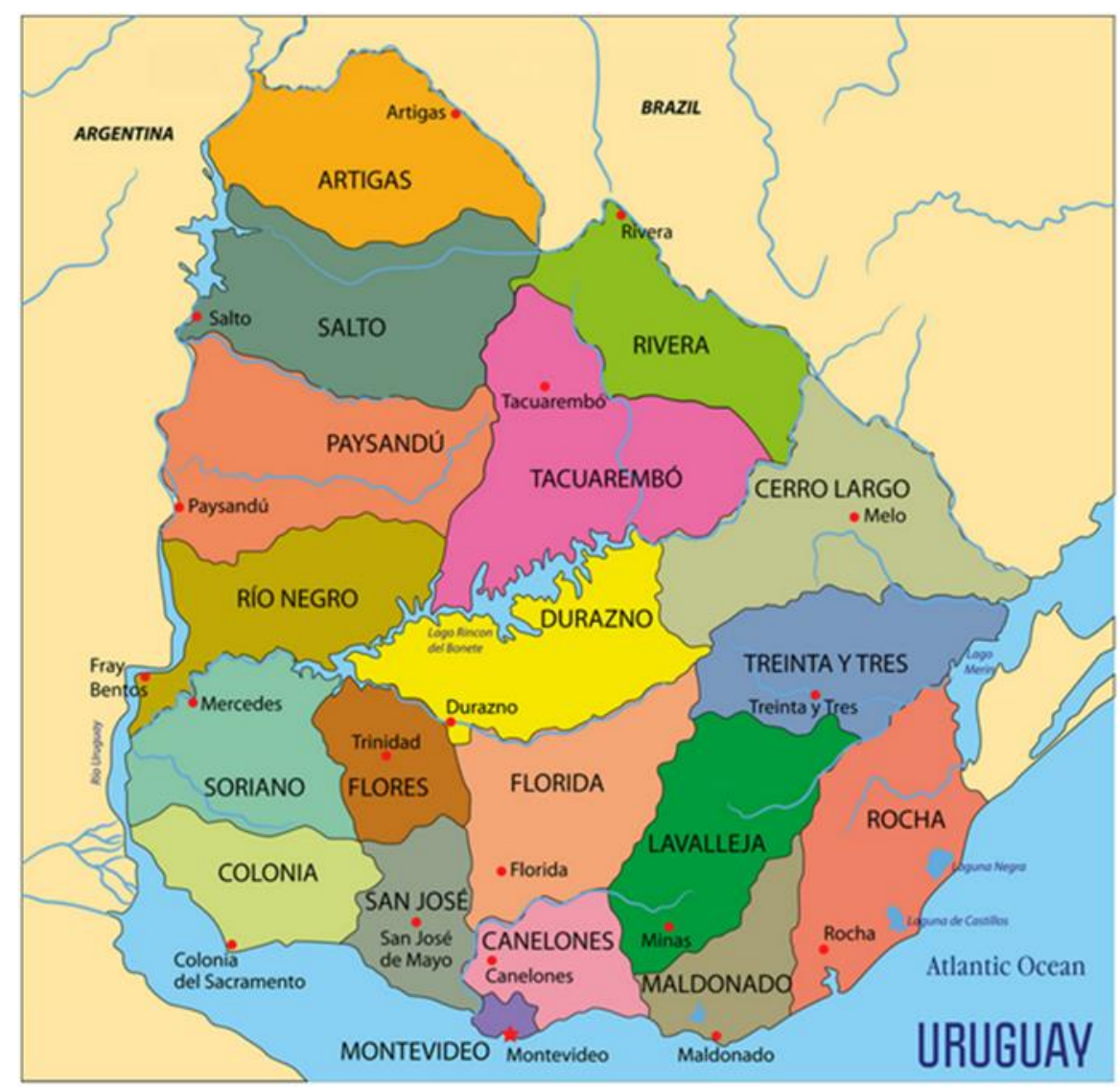

Figure 3 Map of Uruguay with its 19 departments

Source: https://www.vectorstock.com/royalty-free-vector/detailed-map-of-uruguay-withregions-vector-22969371

Intermediaries link the producers with those in the industrial stage. They consist of commission agents, agricultural fairs and other brokers. This last channel is the most used by small producers specialized in breeding for the subsequent sale of their piglets (Uruguay XXI, 2011).

The industrialization phase is composed of slaughterers, companies that in addition to slaughter produce sausage products, companies that only engage in production - whether of imported or domestic meat - and finally companies that sell fresh swine meat (Uruguay XXI, 2011). For companies dedicated to slaughter, it is observed that in 2010 there were 10 qualified companies, of which four were dedicated not only to slaughter, but also to the production of sausages. More than $80 \%$ of the total output is concentrated in these companies (Uruguay XXI, 2011). Two of these companies merged in 2018, controlling $78 \%$ of the national output (La Constancia and Estancia la Celita). Due to the large imported quantities into Uruguay, domestic prices are highly sensitive to international price movements in the pork industry (Gorga, 2018). 


\subsection{Brazil cattle production and industry}

Brazil stands out as the second largest world producer of beef whose main destination is the domestic market. They have implemented measures aimed at monitoring meat quality and ensuring that $78 \%$ of its territory is currently FMD free, increasing the number of exporting states. Likewise, in a large part due to the size of Brazil and as a logistics strategy, internet and television marketing channels for the sale of the cattle were implemented, resulting in a significant expansion (MAGYP, 2014).

Brazil consumes almost all beef production. Brazil consumes $84 \%$ of their produced beef (see Table A.2 in the appendix), exports $16 \%$ of the production and import 40,400 tons (less than $1 \%$ of production) (OECD and FAO, 2019b). The main destinations for Brazilian beef are Hong Kong, China, Egypt, Russia, Iran, Chile, Italy, Saudi Arabia, Singapore and the Netherlands. For these countries, fresh meat without bone represents $80 \%$ of Brazilian exports. The other $20 \%$ is industrialized meat of lower commercial value, destined mainly to the European Union (EU) (Köbrich et al., 2018).

Cattle for slaughter are distributed in the five regions that divide Brazil, see Figure 1: The Central West, Northeast, North, Southeast and South regions. Focusing mainly on the Central West, North and Southeast regions of the country (Köbrich et al., 2018), they contained 79\% of production for slaughter in 2013 (MAGYP, 2014).

The main characteristic of beef in Brazil is the diversity of production systems, adjusted to different biomass and sociocultural aspects of farmers in each area. The result is the absence of standardization of production processes and animals for slaughter. Meanwhile, diversity provides a sectoral competitive advantage, because each productive system can reach a specific type of market, particularly in the case of exports. Increasingly, the Brazilian cattle sector has begun to produce based on markets demand (Köbrich et al., 2018).

Farmers have developed their production systems, to a system of feeding under natural and sown pastures. Production occurs mainly with Zebu cattle in the central west and north of the country. In the south, taurine races and their crosses with Zebu races are more important (Köbrich et al., 2018). Cattle for slaughter mainly consist of the Zebu Nelore breed, which is characterized by being dual purpose, for meat and/or milk. It is a robust animal, the adult male can reach a weight of $800 \mathrm{~kg}$ and females range between 500 and $600 \mathrm{~kg}$ (MAGYP, 2014). The Rio Grande do Sul state where the temperate zone transitions to subtropical, and therefore, no breeds of Zebu (Nelore) are stocked, with production more intensively based on Hereford, Angus, Braford and Brangus breeds (Köbrich et al., 2018). 
Livestock activity for slaughter is characterized by phases of breeding, nursing and fattening. Some producers manage the whole cycle, consisting of breeding (calf production), nursing (weaning calves up to 18 months) and the fattening of castrated male or non-productive female animals for slaughter, while others specialize in each phase (MAGYP, 2014).

Extensive production systems are implemented throughout the country, even where semiintensive and intensive practices predominate. The semi-intensive system is another practice for fattening animals where pasture is used as a base and is supplemented with minerals and protein/energy supplements. The objective of this activity is to achieve fattening of the animal in a shorter period of time, compared to the extensive system. $80 \%$ of food production in semiintensive systems are concentrated in the South-Central part of the country and in small regional centers in the North and Northeast of Brazil. The intensive system differs from the semiintensive system by carrying out confinement practices for animal fattening. This practice is used for breeding, nursing and fattening of cattle. In the confinement system, the objective is to reduce feed costs (MAGYP, 2014).

A form of sales channel is observed through a "concentration of markets". The greatest sales occurs in the South-Central zone of Brazil (approximately $76 \%$ of the total trade). To a lesser extent, the trade of hacienda depends on internet and television channels. Although this practice occurs to a lesser extent, its expansion has been remarkable (MAGYP, 2014).

Currently the processing industry is dominated by three international companies: JBS, Marfrig and Minerva, being responsible for $60 \%$ of the Brazilian exports in 2016. These companies maintain an international presence, with slaughterhouses in several countries worldwide. At each state level (province), there are also many slaughter plants that operate in a limited market, because in general these companies are not qualified to export and market their meat in other states (Köbrich et al., 2018).

\subsection{Chile cattle production and industry}

For the southern regions of Chile, cattle production has important economic and social aspects. This geographic area possesses excellent environmental conditions for livestock production, and hence strong potential growth opportunities. On the other hand, the country has biosecurity protections that constitute an important competitive advantage, and a livestock herd that has a good genetic base. Together with economic liberalization and the network of commercial agreements that Chile has in force, the aforementioned factors have placed bovine meat in a position of high prominence, with opportunities for participation in high demand international markets (Farías et al., 2016). 
Chile is regularly ranked between eighth and tenth place worldwide in overall bovine meat import, but in the per capita rankings it has become number one. In 2017, the main suppliers were Paraguay, Brazil and Argentina (Prieto et al., 2018). Meat imports to Chile mainly consist of chilled, boneless and dispossessed meat (Farías et al., 2016). Nationally, exports have contracted, although there has been a significant recovery since the opening of the beef market in China (Prieto et al., 2018).

Chile has to import beef to cover domestic demand and exports. Chileans consume approximately 453,791 tons of beef per annum (see Table A.2 in the appendix), equating to $100 \%$ (204,752 tons) of domestic beef production. 263,835 tons (equating to $129 \%$ of the domestically produced beef in Chile) are required to be imported to cover domestic demand. Chile exports $7 \%$ of their total produced beef (OECD and FAO, 2019b)

Bovine livestock activity in Chile is distributed throughout the country, but is concentrated (76\%) in the south of Chile, from the Bío Bío region to Los Lagos (see Figure 2). The Bio-Bío region houses $11 \%$ of Chilean cattle, Araucanía 14\%, Los Ríos 18\% and Los Lagos 33\%. It is estimated that $70 \%$ of total cattle are either meat or dual-purpose breeds. From 2007 to date, the number of cattle has fallen $20 \%$ nationwide (Prieto et al., 2018). The value chain of beef in Chile is heterogeneous, fragmented and has no institutions that allow its members to have a long-term strategy to assimilate changes and face new competitors (Farías et al., 2016).

Bovine cattle herds in Chile mostly consist of dual-purpose breeds, with Overo Colorado (Clavel Alemán) and Overo Negro (Holando Europeo) (European), representing approximately $19 \%$ and $8 \%$ of national stocks respectively. Meat breeds are mainly composed of Angus (14\%), Hereford (4\%) and other breeds for meat (2\%) (Rojas, 2019).

Given that the main composition of the national cattle herd is either dual-purpose or dairybreeds, there is a close relationship between these two sectors (meat and milk) in terms of dynamics of animal breeding and the fattening phase. In that sense, there are dairy producers who are dedicated to the raising and fattening of their calves, whether they are dairy or meat breed crosses. Additionally, in situations where dairy rotations occur in the dairy industry, some calves are removed from production and marketed for fattening (either directly or through fairs) (Farías et al., 2016).

Breeders are dedicated to the nursing of calves who may have different purposes other than fattening, which can be extensive or intensive. In the first production form, extensive production, large areas of land and few workers are used. In the intensive second form, greater 
infrastructure is used in spaces of reduced area with greater control over environmental, sanitary and feeding aspects of livestock (e.g. feedlots) (Farías et al., 2016).

Cattle sales between breeding and fattening phases, and subsequently to slaughterhouses, occur mostly through open markets. Transactions via auction occur mainly in the southern zone, and presents a clear tendency to be intra-regional, both for origin and destination. Bovine auctions tend to specialize in livestock for breeding, with calves in the most traded category. The tendency is direct transactions, cattle sales after the fattening phase are made directly between producers and the processing industry, or through livestock fairs or other intermediary agents (Farías et al., 2016).

The slaughter industry brings together agents that coordinate cattle processing on different scales and varying levels of completion of beef products (Farías et al., 2016). As for the processing industry, a tendency to concentrate the slaughter activity in the livestock regions. Processing facilities for cattle have been relocating from close to the centers of consumption, to favoring proximity with productive zones (Farías et al., 2016). The slaughter of cattle is carried out mainly in the regions of Los Lagos, Araucanía and Metropolitana, where the largest slaughter plants are concentrated (Quiroz et al., 2018).

The four largest slaughterhouse companies in the country possess $54 \%$ of the processing capacity (Farías et al., 2016). The Lo Valledor Holding Company (AASA) processes almost $40 \%$ of cattle in Chile at its Santiago, Rancagua, Concepción and Temuco plants with an installed slaughter capacity almost equal to total monthly cattle production in Chile (ODEPA, 2005).

\subsection{Uruguay cattle production and industry}

Climatic conditions, high annual rainfall and soil fertility make Uruguay a region of high potential for livestock production. (MAGYP, 2014) The production of meat is natural, in the field, without the use of hormones, antibiotics and proteins of animal origin, all of which are officially certified, guaranteeing food safety with a quality product that is safe for the consumer. The country has an insignificant BSE risk status and is FMD free, with vaccination (Köbrich et al., 2018). Uruguay continues to be very effective at positioning its cattle/beef sectors as providing natural products, with an efficient traceability program (from cattle to retail) and high food-safety sanitary status. The World Organization for Animal Health (OIE) recognizes Uruguay as FMD free with vaccination and with negligible risk of BSE (Joseph and Meador, 2018). 
Approximately $66 \%$ of beef production is exported, while $34 \%$ is consumed in the domestic market (MAGYP, 2014). More than 70\% of Uruguayan beef exports have three primary destinations: China (52\%), the USA (12\%) and Israel (7\%). Uruguay distributes its production through markets with different requirements such as Israel (kosher), European Union (premium meats), and China (commodity) (Köbrich et al., 2018).

In Uruguay, livestock farming is predominantly extensive, with large tracts of land with low animal density per hectare requiring minimal investment in labor. Intensive livestock production has grown in recent years, with a principle of obtaining maximum benefit in the shortest possible time encouraging increasing yields. Production systems have intensified due to an increase in the price of land that transformed the extensive system because of high land rents (MAGYP, 2014). Additionally, mixed systems of cattle and sheep occupy $80 \%$ of the national territory. British breeds predominante, such as Hereford and Angus, which represent $80 \%$ of the total herd. Continental crosses (Charolais and Limousin) and Indian races and crosses (Braford and Brangus) can also be found (Köbrich et al., 2018).

Within the production systems are breeders who occupy the initial production stage that is established between the birth and weaning of the calf until it reaches a weight of between 160/180 kg (MAGYP, 2014). In this production stage, production systems are characterized by natural pastures, while fattening cattle are located in improved fields (artificial grasslands and winter greens), and according to requirements, supplemented with concentrates (Köbrich et al., 2018). The nursing phase occurs between the weaning of the calf until they reach a weight of between $250 / 300 \mathrm{~kg}$. Fatteners "invernada" are those that provide the last stage of production, and are dedicated to fattening and increasing muscle mass, with a forage base of grasslands, winter and summer greens, and grain supplementation. The complete cycle is often carried out by many producers that conduct both breeding and wintering in the same establishment, achieving greater flexibility and greater added value (MAGYP, 2014).

The supply chain for the industry has intermediate stages such as the sale for fattening (to fattening producers or fattening farms). The production of calves can be used by nurseries for replacement, as live exports, or invernadas for subsequent slaughter and destined for the domestic or export market. In recent years, given the rise in the importation of standing calves by Turkey, almost all of the calves go to that destination, which has reconfigured the market for calves in Uruguay. (Köbrich et al., 2018).

In Uruguay there are different levels of commercialization, where an animal is on average sold three times during its life. A large percentage of livestock sales for replacement are marketed 
through television channels, while for slaughter it is advertised through desks (consignees) which negotiate with the processing plants, or through direct sales (MAGYP, 2014).

Nursery animals of more than one year are mainly sold to fattening farms (invernadas) through commercial desks that charge a commission for each transaction. The route can be directly between two producers or through public auctions facilitated through fairs and television. In the sales process, the corral selects its customers and animals, making agreements and buying the animal directly, or through desks, intermediaries or consignees. The Association of Livestock Consignees (Asociación de Consignatarios de Ganado, ACG) is a union that promotes the professionalization of consignees, and is present at the time a cattle producer does business with another producer or industry actor. According to this association, in Uruguay $50 \%$ of the cattle that are slaughtered are sold through consignees. The ACG has more than 400 partner consignee companies throughout the country (Köbrich et al., 2018).

In Uruguay, there are currently 37 slaughterhouses authorized in the country, which process $99 \%$ of the slaughtered cattle, and 23 are authorized to export to various world markets (Köbrich et al., 2018). There are located in different areas of the country, concentrated mostly in the south, in the departments of Canelones and Montevideo, see Figure 3, which consists of more than $75 \%$ of the total work (MAGYP, 2014).

The percentage of the slaughter controlled by the four largest firms was $56 \%$ in $2017 / 18$ : Marfrig 22\%, Minerva 18\%, BPU-NH Foods 8\%, Las Piedras S.A. 8\%. The eight largest firms represent $73 \%$ of the slaughter in the country (Gorga, 2018). Foreign investment in Uruguay's slaughter facilities accounts for roughly $54 \%$ of the total slaughter. The Brazilian company, Marfrig, operates four plants that accounted for $22 \%$ of the total, with another Brazilian company, Minerva, operating three plants that accounted for $18 \%$. Japanese and Chinese investors recently purchased meat processing plants in Uruguay. Three large plants are owned (mostly) by Uruguayan entities with the rest being medium and small-scale plants (Joseph and Meador, 2018).

An overview of the different pig and cattle production systems in Brazil, Chile and Uruguay can be seen in Table A.3 in the appendix. 


\section{Chapter 3 Cycles in cattle and pig prices in South America $^{5}$}

Autoren: Astrid Fliessbach and Rico Ihle

Keywords: cattle cycle, Kalman filter, pig cycle, pork cycle, price fluctuations, state space models

\subsection{Introduction}

Agricultural markets are characterized by regular price fluctuations of varying degrees. Krugman (2008, pp. A21) in his column for the New York Times pointed out that "over the past few years the prices of wheat, corn, rice and other basic foodstuffs have doubled or tripled. High food prices are truly devastating in poor countries, where food often accounts for more than half a family's spending”. The implications of food price fluctuations are also acknowledged by international institutions dealing with agriculture and food markets. For example, the World Bank has established "Food Price Watch" in order to inter alia outline the policy implications of food price fluctuations (World Bank Group, 2018). The FAO has authored a number of policy documents that assess the magnitude of food price fluctuations and recommend ways to deal with them (Barker et al., 2009).

Price fluctuations are a normal attribute as well as a necessary prerequisite for functioning competitive markets (FAO, 2010). These price fluctuations may be regular or irregular, have various durations, and can potentially overlap so that they may enforce or neutralize each other. Substantial fluctuations are reported to be caused by weather, technology or other supplyrelated shocks; the more inelastic demand is - as is the case with most food products - the more pronounced they will be. The pork cycle is one example of such regular fluctuations. This phenomenon is a regular pattern observed in pork slaughter prices first noticed by Hanau (1928), having a duration of three to four years. Similar regular cyclical patterns have been observed in cattle slaughter prices. For example, Mundlak and Huang (1996) found that such cattle cycles re-appear every six to ten years.

\footnotetext{
${ }^{5}$ This chapter has made few changes to the paper "Cycles in cattle and pig prices in South America" submitted to The Australian Journal of Agricultural and Resource Economics (AJARE).
} 
Monitoring agricultural price cycles creates insights into the current status of medium-run price dynamics. Therefore, we aim to measure price cycles in the context of South America, as it is a major meat production region worldwide and livestock activity is connected with $85 \%$ of total Latin American agricultural area (ECLAC, FAO and IICA, 2017). Therefore, the main question of this research consists of whether cycles in South American agricultural prices can be isolated, how they are shaped and which statistical characteristics, such as cycle duration or amplitude, they have. We focus on agricultural prices in the pig and cattle sectors of Brazil, Chile and Uruguay as they represent major meat producing countries in the region. ${ }^{6}$

Section 3.2 presents the key characteristics of agricultural price cycles, followed by determinants of agricultural price cycles in Section 3.3. Section 3.4 gives an overview of the current literature on agricultural price cycles. Section 3.5 includes a brief descriptive analysis of the data. Afterwards, the methodology used to model price cycles is outlined in Section 3.6 before the results of our empirical analysis are presented in Section 3.7. Section 3.8 summarizes the main results, relates them to the existing literature and concludes the paper.

\subsection{Characteristics of agricultural price cycles}

This section defines characteristics of price cycles. A cycle of agricultural prices is usually understood as a periodic price fluctuation lasting more than one year (Koester, 2010). Cycles may arise due to regular changes in supply and demand. Ezekiel (1938) stressed the temporal delay necessary for the adaptation of quantities supplied by farmers as a key determinant. Hanau (1928) and Coase and Fowler (1935) published seminal academic papers on this phenomenon - known as the pork cycle or cobweb theorem - analyzing the pork markets in Germany and Great Britain, respectively. More recent literature indicates the existence of cycles in cattle prices in the USA, Argentina and Uruguay (Mundlak and Huang, 1996), and in pork prices in the USA and Europe (Holst and von Cramon-Taubadel, 2012) and China (Fengying et al., 2009).

In order to be explicit about the statistical characteristics of price cycles, we define the following crucial features. The duration of one full cycle is referred to as cycle length or period. The vertical distance between the long-run trend, determining the direction of the movement of the cycle in the long run, to a peak or trough is the cycle's amplitude. The long-run trend is assumed to be linear in Figure 4 for simplicity but can also take any other smooth functional form.

\footnotetext{
${ }^{6}$ It was not possible to include Argentina as no prices were available.
} 
The only element in this graph that can be empirically observed is the price series $y_{t}$. This observed price series needs to be decomposed into single components as shown in Figure 4 according to the following additive time series model (1):

$$
y_{t}=\mu_{t}+c_{t}+\gamma_{t}+\varepsilon_{t} \quad t=1, \ldots, T .
$$

The variable $y_{t}$ measures the observed price in a given country in each period $t$ with $T$ being the number of total observations. The component $\mu_{t}$ measures the smooth long-run timedependent trend, $c_{t}$ quantifies the cycle component, $\gamma_{t}$ is the seasonal component, and $\varepsilon_{t}$ denotes the unexplained white noise component.

Burns and Mitchell (1946) authored the classical book of cycle analysis. A formal methodology of how to detect and describe cycles has been developed by Harding and Pagan (2002). They define three steps to detect cycles: the detection of potential set of turning points, i.e. the peaks and troughs in a series; a procedure for ensuring that peaks and troughs alternate; a minimum duration of a phase lasting at least half a year and a complete cycle having a minimum duration of 15 months.

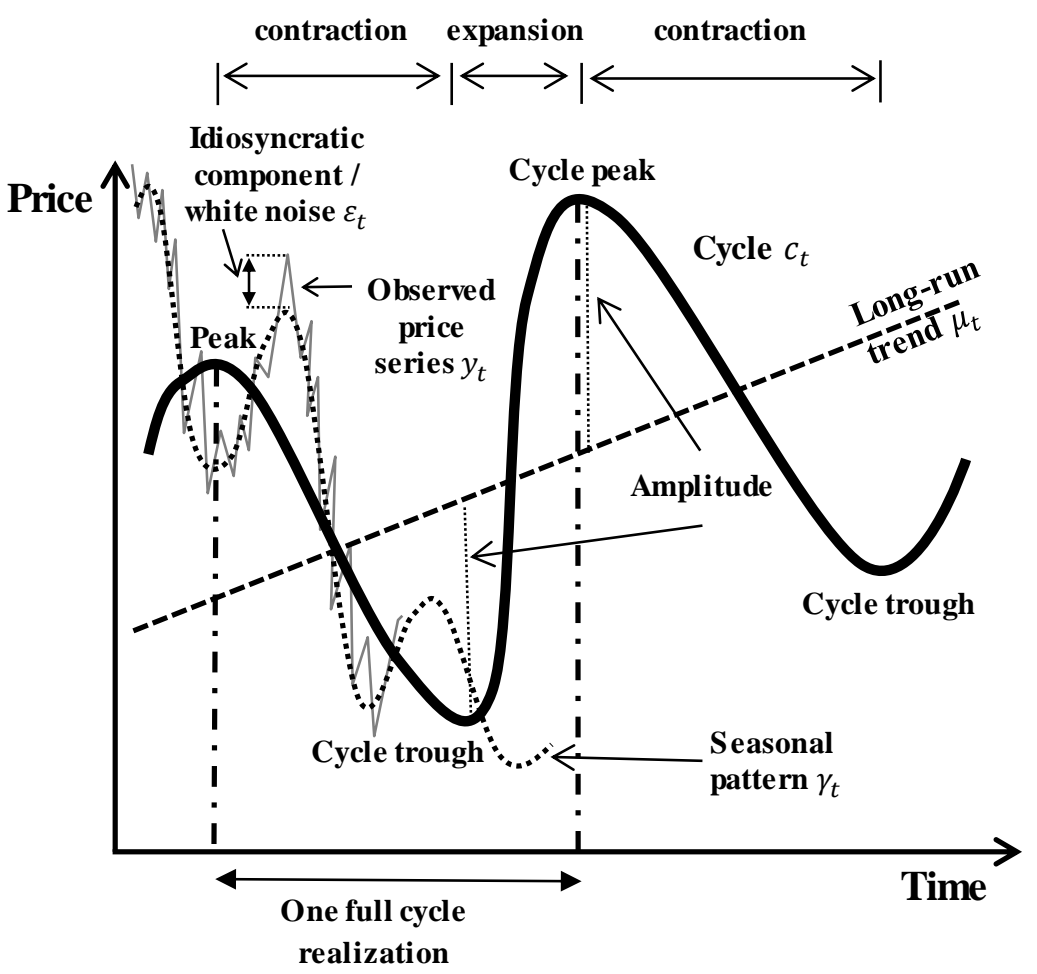

\section{Figure 4 Characteristics of price cycles}

Source: Authors based on Goodwin (1994, pp. 158)

One theoretical explanation of such a regular price patterns is the delayed reaction by producers to generate agricultural supplies due to biological production constrains. These can be 
substantial, especially in livestock production. For livestock producers this delay is determined by the time from insemination to slaughter (gestation, nursing and fattening), which effects producers' ability to respond by adjusting supplied quantities to price changes. Figure 5 displays typical production cycles of pig and cattle. On average, from the point when the producer decides to increase her cattle herd, it takes about 4.5 years until increased quantities of beef appear on the market due to the overall production process. 24 months after birth, a heifer can be inseminated, after 10 additional months a calf is born, which then needs to be fattened for one and a half to two years until ready for slaughter. For pigs, the production process consists of the same steps but with one and a half years, has a substantially shorter duration (right panel of Figure 5). Goodwin (1994, pp. 104) mentions a rule of thumb for the length of a livestock reproduction cycle: "The minimum length of a cycle (from peak (trough) to peak (trough)) is about quadruple the time required from birth to first reproduction".

Anderson et al. (1996) argue that since the middle of the 1980's, the cattle business has exhibited cyclical fluctuations, e.g., as cow-calf producers expand inventories in response to profits incurred and, ultimately, contract herd sizes in response to losses. Calf producers respond to profitable prices by holding back more replacement heifers and slaughtering less cows in order to produce more calves for the coming year. However, additional heifers held back for entry into the herd do not increase beef production for at least 2.5 years (see Figure A.1 in the appendix), as they first need to reach sexual maturity. Eventually, the increase in cattle inventory, and subsequent beef supplies, leads to a lower price $\left(\mathrm{P}_{2}\right.$ in Figure A.1). Ultimately, prices decline below many cattle producers' break-even level, which leads to higher costs and firms starting to liquidate their herds. Herd liquidation continues until prices return to profitable levels. The time it takes production to respond to higher (lower) prices creates a lag between price peaks such as $\mathrm{P}_{1}$ (troughs) and subsequent inventory peaks (troughs). Producers expand and reduce their herds according to the expected profit, and the supply cannot be immediately adapted to the demand, resulting in price cycles. 

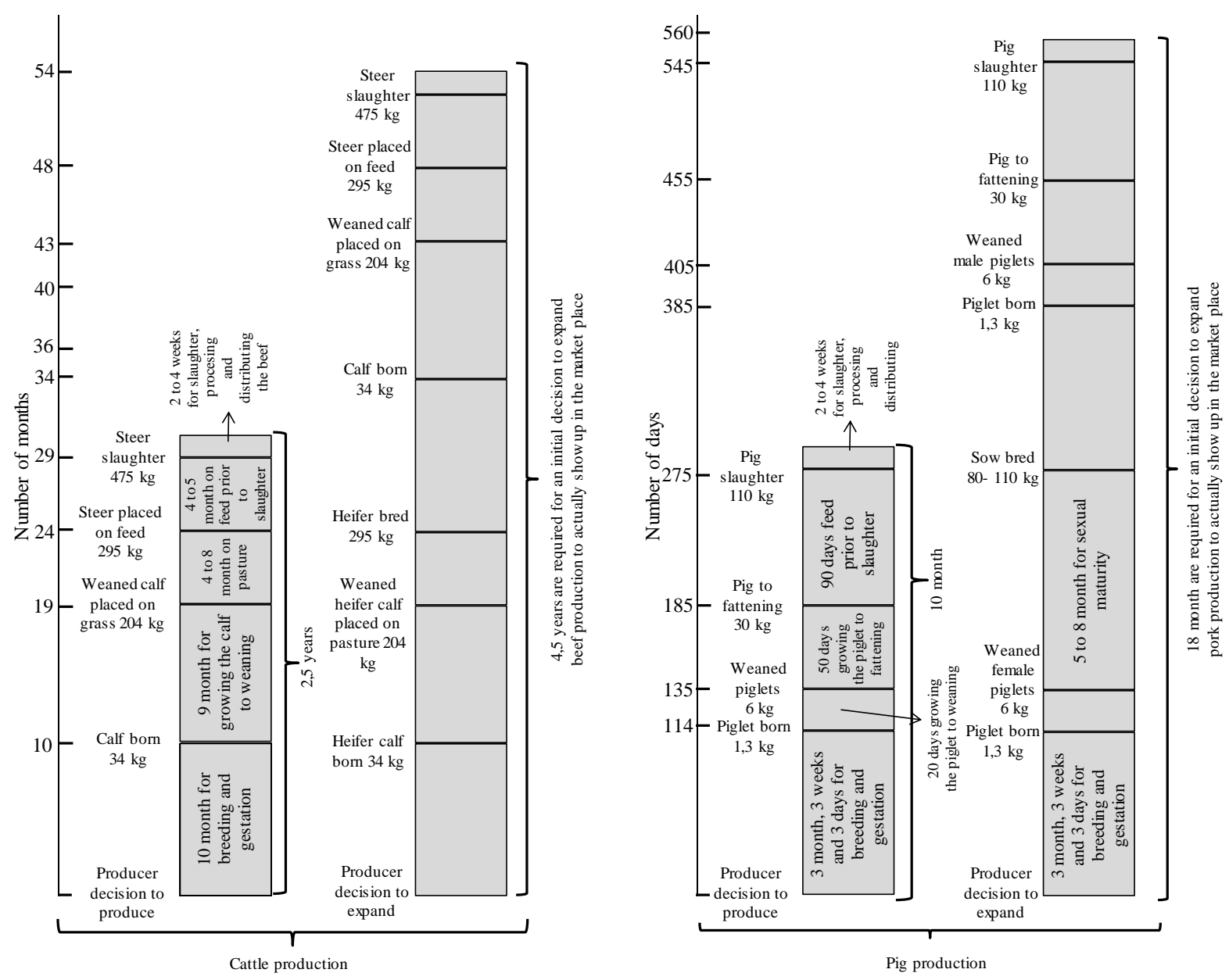

Figure 5 Stages of pig and cattle production cycles

Source: Authors based on Goodwin (1994, pp. 107) and PIC (2015, pp. 35).

Regular fluctuations in consumption patterns and meat demand, as well as supply chain instabilities such as the so-called bullwhip effect, are also likely to contribute causing price cycles.

\subsection{Determinants of agricultural price cycles}

Not all agricultural products display price cycles. Cycles are more likely to be observed for livestock, livestock products and tree crops, which all require relatively long time periods for supply quantities adapting to changed market prices (Tomek and Kaiser, 2014). A delay in the adaption in quantities supplied is a consequence of this inability to change production quantities instantaneously. Such supply delay refers to the amount of years required to adjust production, the time to achieve the optimal slaughter weight, or the time until fruits can be harvested. It does not only depend on farmers' decisions, but also on the nature of the production process of the commodity (hogs, cattle or perennial tree crops). Section A.1 of the appendix provides a detailed account of the classical underlying model. 
Koester (2010) mentions the role of another exogenous factor, the so-called echo effect, which disturbs economic equilibrium causing price cycles due to production alterations. This echo effect arises, potentially due to political destabilization or natural disaster and causes simultaneous replacement of production inputs, in manifestations such as the large-scale destruction or establishment of new infrastructure or herd regeneration, both of which may result in a synchronized production cycle.

Country-specific business cycles are another exogenous price cycle formation factor that influences the investment and the consumption patterns in a country (Koester, 2010). Increases in disposable income due to an economic boom and low unemployment, for instance, are likely to influence meat consumption patterns. Consumers having low income generally prefer cheaper protein sources; with increasing incomes, however, consumption preferences may change, so that poorer households purchase temporarily more meat (ODEPA, 2007; Bifaretti, Brusca and Jairala, 2014).

Hanau's pork cycle and Ezekiel's cobweb theorem are based on naive producer price expectations, which the current literature mostly considers as not being an adequate assumption. Naive expectations refer to the belief that current prices are going to remain constant in the next future. Such expectations do, however, not consider the ability of producers to learn from past experiences. Nerlove (1958) introduces adaptive price expectations, at each new period the individual revises his expectation of the future price in view of his current expectation error, i.e., the discrepancy between his expectation of the current price and the actual current price.

A more modern approach to price expectations is the rational expectation developed by Muth (1961). It extends the principle of individual rationality from the problem of the allocation of resources to that of the formation of expectations. The individual is supposed to use all of the available pertinent information when formulating her forecast of prices. This model is generally considered to correspond more closely to the real world conditions of information availability because it allows for a stochastic model formulation. Pashigian (1970) concludes that this stochastic formulation suggests that the price cycle is attributed to the summation of random walks, resulting in cycles of mean length longer than that of the deterministic cobweb model with naive price expectation.

Pork production patterns in Brazil depend on the region. In the south, mainly small producers integrated and associated, each of them specialized in specific production phases (breeding and gestation, growing phase, fattening, etc.). In the southeast, producers are mostly integrated covering the whole production process (Fava et al., 2016). In general, a system of quasi- 
integration dominates: small and medium farms produce for food firms or cooperatives on a contractual basis, receiving access to genetics, food, medication, supervision and technical support (Lima, 2015). In 2015, cooperatives and the five biggest pork firms slaughtered 56\% of domestic production. In Uruguay, the pork sector has been experiencing production concentration and intensification implemented by large producers. Again, domestic price are reported to be substantially influenced by international ones (Bell et al., 2014). Pork production in Chile is input- and technology-intensive, mostly vertically integrated and highly concentrated between few actors (Acuña and Pizarro, 2019).

In the Brazilian and Uruguayan cattle sector, price discovery occurs in the region of sale. Cattle are sold directly to slaughterhouses and later on to refrigerated storage houses (frigorificos). Only a minor part is traded through intermediaries or agents. In Brazil, marketing by farmers is concentrated in regional marketplaces. In Uruguay, the trade of replacement cattle is facilitated between farms via television, avoiding the cattle transport to regional markets. Cattle in slaughter weight are sold via a consignee taking care of further arrangements with slaughterhouses/refrigerating storage houses. Sales also occurs directly between producer and slaughterhouse (ODEPA, 2005). In Chile, livestock auctions are the main price discovery mechanism, even though the quantity traded through this channel is only about $30 \%$ of the total. The remaining cattle are sold directly between producers and slaughterhouses. Farías, Espinoza and Giacomozzi (2016) report significant price transmission from international to domestic Chilean prices adding variability to farm-gate selling prices.

\subsection{Current empirical evidence}

Price cycles have been assessed for a number of agricultural markets. Table A.4 in the appendix contains a list of publications on price cycle lengths in pork and cattle production between 1928 and 2016. The table highlights the methodologies used and the estimated cycle durations. Seven of these studies look at pork price cycles for the USA, two studies in Germany, and one study in Great Britain, Canada and China respectively. Cattle price cycles have been studied several times for the USA and Canadian markets (three studies for each respectively), but only once, more than 20 years ago, for Argentina and Uruguay (Mundlak and Huang, 1996).

As shown in Table A.4, 36 to 48 months is the most frequent estimate of the length of the pork price cycle in the considered publications. The cattle price cycle has frequently been found to stretch over a period of approximately 120 months (Table A.4). Mundlak and Huang (1996) found a length of only 72 months for Argentina and Uruguay. The longest and shortest price cycle periods reported in the literature are 84 and 33 months for pork and 132 and 76 months 
for cattle, respectively. Harmonic analysis and the Hodrick-Prescott-Filter are the most frequently used methodologies applied for analyzing pork price cycles. Spectral decomposition is the most often used approach implemented for analyzing cattle price cycles.

The empirically estimated cycle lengths of about 36 months (Table A.4) correspond to two pork production periods of about 18 months according average production periods (Figure 5). The cattle price cycles of 120 months of Table A.4 are fairly close to the 108 months (two times 4.5 years) of the typical cattle production cycle.

All empirically estimated cattle cycle lengths shorter than 120 months do not agree with Goodwin's (1994) rule of thumb regarding cycle length, according to which four times the duration from birth to the first reproduction (4 times 34 months) represents one cycle. The same holds for pork cycles shorter than 48 months (four times 12 months).

The most recent contributions to the analysis of pork and cattle price cycles have been authored by Berg and Huffaker (2015) and Twine et al. (2016), respectively. Berg and Huffaker (2015) identify two important causal factors of price cycles using a diagnostic modeling approach based on non-linear time series analysis. The first factor is the irreversibility of investments due to sunk costs caused by the high specificity of the production technology, which impedes a switch from pork production to other commodities without losing the investment. The second factor is the liquidity-driven investment behavior of farmers in Germany, who need financial consolidation after a large investment before they decide to make another one. Twine et al. (2016) found a ten-year price cycle of slaughtered steers using a spectral decomposition.

\subsection{Data}

We analyze real monthly farm-gate prices of pig and cattle in Brazil, Chile and Uruguay. ${ }^{7}$ Table A.5 in the appendix gives an overview of the data sources, exact descriptions of the types of prices used as well as their respective currencies. Analyzed prices are based on nominal, monthly farm-gate selling prices of live animals. The raw data are transformed into real prices in national currency using domestic CPIs with January 2001 as base. The total number of observations (T) considered in the pig price series are: 324, 492 and 300 for Brazil, Chile and Uruguay, respectively. In the cattle price series, the total numbers of observations (T) considered are: 324, 492 and 396 for Brazil, Chile and Uruguay, respectively.

Table A.6 in the appendix summarizes the descriptive statistics of the data. For each series, mean and median almost equal each other pointing to fairly symmetric price distributions. The

\footnotetext{
${ }^{7}$ For Argentina, no prices were available.
} 
coefficient of variation $(\mathrm{CV})$ is 0.3 of pig producer prices in Brazil and Chile, and 0.4 for Uruguay. The $\mathrm{CV}$ of cattle prices of all three countries is 0.2 , indicating a similar degree of relative dispersion for all three cases. Figure A.4 and A.5 in the appendices provide insight into annual relative price movements by neglecting the seasonal intra-year variations.

\subsection{Methodology}

We employ the Kalman filter (Kalman, 1960), which takes full advantage of the information available in the time series. Structural time series models are formulated in terms of unobserved components that have a direct interpretation. The statistical treatment of such models is based on the state space form (Carvalho and Harvey, 2005). The Kalman filter is a time-varying stochastic process that decomposes times series into a smoothed long-run trend, a cycle, as well as a seasonal and an irregular component as formulated in equation (1). Estimation of the trend, the cycle and seasonal components is based on a state-space model with time-varying parameters that results in smooth non-parametric, typically non-constant estimates. For the analysis, the additive structural model (1) is used in which we account for automatically selected $^{8}$ level and slope breaks which are not explicitly mentioned in equation (1). The trend component is the smooth growth or decline in the long term modeled as (2):

$$
\mu_{t}=\mu_{t-1}+\beta
$$

where $\beta$ is the deterministic slope of the trend. The stochastic cyclical component $c_{t}$, which measures the deviations of the observed price series from the long-run trend $\mu_{t}$ cleaned from the seasonal component $\gamma_{t}$ and the error term $\varepsilon_{t}$, is estimated as (3):

$$
\left[\begin{array}{l}
c_{t} \\
c_{t}^{*}
\end{array}\right]=\rho\left[\begin{array}{c}
\cos \lambda_{c}+\sin \lambda_{c} \\
-\sin \lambda_{c}+\cos \lambda_{c}
\end{array}\right]\left[\begin{array}{c}
c_{t-1} \\
c_{t-1}^{*}
\end{array}\right]+\left[\begin{array}{l}
\varpi_{t} \\
\varpi_{t}^{*}
\end{array}\right]
$$

with $\lambda_{c}$ being the cycle frequency. The parameters $\varpi_{t}$ and $\varpi_{t}^{*}$ are normally distributed and mutually independent white noise disturbances with identical variances, that is, $\varpi_{t} \sim \mathrm{N}\left(0 ; \sigma_{\varpi}^{2}\right)$ and $\varpi_{t}^{*} \sim \mathrm{N}\left(0 ; \sigma_{\varpi}^{2}\right)$.

The parameter $0<\rho<1$ is the dampening factor of a stationary process; if $\rho=1$ the stochastic cyclical process is non-stationary. The period of the cycle can be calculated via $2 \pi / \lambda_{c}$.

\footnotetext{
${ }^{8}$ The automatic break detection is based on the auxiliary residuals and consists of a two-step procedure. First the selected model is estimated and the diagnostics are investigated. Then a first (larger) set of potential level and sloped trend breaks are selected from the auxiliary residuals. After re-estimation of the model, only those interventions that survive are sufficiently significant.
} 
Seasonality is a regular and predictable price pattern within individual years. The seasonal component is modeled as a seasonal dummy model. This concept and the possibility of letting the seasonal pattern change over time results in the formulation (4):

$$
\gamma_{t+1}=-\sum_{j=1}^{s-1} \gamma_{t+1-j}+\omega_{t} \quad \omega_{t} \sim N\left(0 ; \sigma_{\omega}^{2}\right)
$$

where $\gamma_{t+1}$ is the seasonal component, $s$ is the number of periods per year ( $s=12$ for monthly data), and $\omega_{t}$ is a normally distributed disturbance term.

Once the model has been specified, the Kalman filter yields estimates of the unknown variances $\sigma_{\varpi}^{2}, \sigma_{\omega}^{2}$ and $\sigma_{\varepsilon}^{2}$ and the unobserved components cycle amplitude, period, $\rho$ and $\lambda_{c}$. These estimates are obtained from one-step-ahead prediction error estimations using maximum likelihood. A smoothing algorithm produces the final estimates of the components for all observations so that the key outputs are graphs.

We consider three potential specifications for each country and product when selecting the most adequate specification. All eighteen models include a deterministic level and a stochastic cycle, the differences between the models lay in the inclusion of a deterministic slope and/or stochastic seasonality; the first version of each model (M1) includes a deterministic level, with a stochastic cycle (equation (3)) and without slope and seasonality; the second model (M2) with a deterministic level and slope (equation (2)), stochastic cycle (equation (3)) and without seasonality; and the third model (M3) a deterministic level and slope (equation (2)), stochastic cycle (equation (3)) and stochastic seasonality (equation (4)).

We select the most adequate specifications of each univariate model for each commodity and country based on comprehensive residual testing and model selection criteria. The challenge is to obtain an interpretable and applicable model with as desirable as possible residual characteristics. $^{9}$ Only focusing on statistical characteristics can lead to complex and uninterpretable models. Therefore, the foundation of our model selection process is obtaining a sensible interpretability of the estimation results and as optimal as possible statistical characteristics.

First, we test each of the eighteen models to for residual normality, homoscedasticity and autocorrelation. Considering three possible specifications for each country and product, we select the most adequate model with the best residual properties and, if more than one model is

\footnotetext{
${ }^{9}$ The criteria employed are normal distribution, autocorrelation, heteroscedasticity and smallest selection criteria. In the ideal case, both model selection strategies yield consistent results: the models having optimal residual characteristics also show minimum selection criteria and are straightforwardly interpretable. However, in empirical analysis, this rarely appears to be the case.
} 
obtained, then choose the model with the smallest selection criteria. The residual testing checks whether there is sufficient evidence against that model, whether residuals are normally distributed (using the Bowman-Shenton test (Bowman and Shenton, 1975)), whether they are homoscedastic (tested with a two-sided F-test) and not autocorrelated (using the test of Durbin and Watson (1950) as well as the Ljung and Box (1978) statistic). Model selection is also based on Akaike's Information Criterion (AIC; (Akaike, 1974)).

\subsection{Results}

As indicated in Table A.7 in the appendix, the finally chosen models have homoscedastic and mostly normally distributed residuals, which, however, show autocorrelation to a low extent. We decided to not integrate autocorrelation corrections in order to avoid complex and uninterpretable models.

Table 1 presents the finally selected model specifications for each of the six cases. The most appropriate models for pig in Chile as well as pig and cattle in Brazil are deterministic linear trend models with fixed drift ${ }^{10}$ including a stochastic cycle, seasonality and structural breaks. ${ }^{11}$ The best fitting models for Uruguayan pig and cattle as well as Chilean cattle are deterministic linear trend models with fixed drift including a stochastic cycle and structural breaks, but without a seasonal component.

\footnotetext{
${ }^{10}$ Drift is the expression for the inclusion of a slope term in the long-run trend.

${ }^{11}$ The structural breaks included in the corresponding models are shown in Table A.7 in the appendix.
} 
Table 1 Selected models and equations by country and product

\begin{tabular}{|c|c|}
\hline Model & Model equation \\
\hline $\begin{array}{l}\text { Brazil pig } \\
\text { (M3) }\end{array}$ & $\begin{array}{l}y_{t}=\mu_{t}+c_{t}+\gamma_{t}+\varepsilon_{t} \\
\mu_{t}=\mu_{t-1}+\beta \\
{\left[\begin{array}{l}c_{t} \\
c_{t}^{*}\end{array}\right]=\rho\left[\begin{array}{c}\cos \lambda_{c}+\sin \lambda_{c} \\
-\sin \lambda_{c}+\cos \lambda_{c}\end{array}\right]\left[\begin{array}{l}c_{t-1} \\
c_{t-1}^{*}\end{array}\right]+\left[\begin{array}{l}\varpi_{t} \\
\varpi_{t}^{*}\end{array}\right]} \\
\gamma_{t+1}=-\sum_{\mathrm{j}=1}^{s-1} \gamma_{t+1-j}+\omega_{t}\end{array}$ \\
\hline $\begin{array}{l}\text { Chile pig } \\
\text { (M3) }\end{array}$ & $\begin{array}{l}y_{t}=\mu_{t}+c_{t}+\gamma_{t}+\varepsilon_{t} \\
\mu_{t}=\mu_{t-1}+\beta \\
{\left[\begin{array}{l}c_{t} \\
c_{t}^{*}\end{array}\right]=\rho\left[\begin{array}{c}\cos \lambda_{c}+\sin \lambda_{c} \\
-\sin \lambda_{c}+\cos \lambda_{c}\end{array}\right]\left[\begin{array}{l}c_{t-1} \\
c_{t-1}^{*}\end{array}\right]+\left[\begin{array}{l}\varpi_{t} \\
\varpi_{t}^{*}\end{array}\right]} \\
\gamma_{t+1}=-\sum_{\mathrm{j}=1}^{s-1} \gamma_{t+1-j}+\omega_{t}\end{array}$ \\
\hline $\begin{array}{l}\text { Uruguay pig } \\
\text { (M2) }\end{array}$ & $\begin{array}{l}y_{t}=\mu_{t}+c_{t}+\gamma_{t}+\varepsilon_{t} \\
\mu_{t}=\mu_{t-1}+\beta \\
{\left[\begin{array}{l}c_{t} \\
c_{t}^{*}\end{array}\right]=\rho\left[\begin{array}{r}\cos \lambda_{c}+\sin \lambda_{c} \\
-\sin \lambda_{c}+\cos \lambda_{c}\end{array}\right]\left[\begin{array}{l}c_{t-1} \\
c_{t-1}^{*}\end{array}\right]+\left[\begin{array}{l}\varpi_{t} \\
\varpi_{t}^{*}\end{array}\right]}\end{array}$ \\
\hline $\begin{array}{l}\text { Brazil cattle } \\
\text { (M3) }\end{array}$ & $\begin{array}{l}y_{t}=\mu_{t}+c_{t}+\gamma_{t}+\varepsilon_{t} \\
\mu_{t}=\mu_{t-1}+\beta \\
{\left[\begin{array}{l}c_{t} \\
c_{t}^{*}\end{array}\right]=\rho\left[\begin{array}{c}\cos \lambda_{c}+\sin \lambda_{c} \\
-\sin \lambda_{c}+\cos \lambda_{c}\end{array}\right]\left[\begin{array}{l}c_{t-1} \\
c_{t-1}^{*}\end{array}\right]+\left[\begin{array}{l}\varpi_{t} \\
\varpi_{t}^{*}\end{array}\right]} \\
\gamma_{t+1}=-\sum_{j=1}^{s-1} \gamma_{t+1-j}+\omega_{t}\end{array}$ \\
\hline $\begin{array}{l}\text { Chile cattle } \\
\text { (M2) }\end{array}$ & $\begin{array}{l}y_{t}=\mu_{t}+c_{t}+\gamma_{t}+\varepsilon_{t} \\
\mu_{t}=\mu_{t-1}+\beta \\
{\left[\begin{array}{l}c_{t} \\
c_{t}^{*}\end{array}\right]=\rho\left[\begin{array}{r}\cos \lambda_{c}+\sin \lambda_{c} \\
-\sin \lambda_{c}+\cos \lambda_{c}\end{array}\right]\left[\begin{array}{l}c_{t-1} \\
c_{t-1}^{*}\end{array}\right]+\left[\begin{array}{l}\varpi_{t} \\
\varpi_{t}^{*}\end{array}\right]}\end{array}$ \\
\hline $\begin{array}{l}\text { Uruguay cattle } \\
\text { (M2) }\end{array}$ & $\begin{array}{l}y_{t}=\mu_{t}+c_{t}+\gamma_{t}+\varepsilon_{t} \\
\mu_{t}=\mu_{t-1}+\beta \\
{\left[\begin{array}{l}c_{t} \\
c_{t}^{*}\end{array}\right]=\rho\left[\begin{array}{r}\cos \lambda_{c}+\sin \lambda_{c} \\
-\sin \lambda_{c}+\cos \lambda_{c}\end{array}\right]\left[\begin{array}{l}c_{t-1} \\
c_{t-1}^{*}\end{array}\right]+\left[\begin{array}{l}\varpi_{t} \\
\varpi_{t}^{*}\end{array}\right]}\end{array}$ \\
\hline
\end{tabular}

Source: Authors.

Table 2 shows the amplitude of the estimated cycles. ${ }^{12}$ The cycles of the Brazilian pig and cattle prices have an amplitude of $0.004 \mathrm{R} \$ / \mathrm{kg}$ and $0.012 \mathrm{R} \$ / \mathrm{kg}$ which are of minor magnitude of only $0.4 \%$ and $0.5 \%$ of its average pig and cattle, respectively prices. The cycles of the Uruguayan pig and cattle prices have an amplitude of $1.1 \mathrm{Ur} \$ / \mathrm{kg}$ and $0.976 \mathrm{Ur} \$ / \mathrm{kg}$

\footnotetext{
${ }^{12}$ For the sake of simplicity, we only present the results regarding the price cycles, as this is the focus of our analysis. Further results may be obtained from the authors upon request.
} 
corresponding to $7 \%$ and $8 \%$ of its average pig and cattle prices, respectively. The Chilean pig and cattle price cycles have an amplitude of $535 \mathrm{Ch} \$ / \mathrm{kg}$ and $961 \mathrm{Ch} \$ / \mathrm{kg}$ corresponding to $96 \%$ and $157 \%$ of the respective average pig and cattle prices, respectively. Hence, Chile has the highest and Brazil the smallest relative cycle amplitudes ${ }^{13}$ for pig and cattle prices as also visible in Figure 6 and 7.

Table 2 Estimated price cycle parameters for pig and cattle prices by country

Pig

Brazil Chile Uruguay

\section{Parameters}

\begin{tabular}{|c|c|c|c|c|c|c|}
\hline $\begin{array}{l}\text { Average } \\
\text { amplitude }\end{array}$ & $\begin{array}{l}0.004 \\
\mathrm{R} \$ / \mathrm{kg}\end{array}$ & $\begin{array}{c}534.8 \\
\mathrm{Ch} \$ / \mathrm{kg}\end{array}$ & $\begin{array}{c}1.1 \\
\mathrm{Ur} \$ / \mathrm{kg}\end{array}$ & $\begin{array}{l}0.012 \\
\mathrm{R} \$ / \mathrm{kg}\end{array}$ & $\begin{array}{c}961.2 \\
\mathrm{Ch} \$ / \mathrm{kg}\end{array}$ & $\begin{array}{c}0.976 \\
\mathrm{Ur} \$ / \mathrm{kg}\end{array}$ \\
\hline $\begin{array}{l}\text { Relative } \\
\text { cycle }\end{array}$ & $0.4 \%$ & $96 \%$ & $7 \%$ & $0.5 \%$ & $157 \%$ & $8 \%$ \\
\hline $\begin{array}{l}\text { Period } \\
2 \pi / s \lambda_{c}\end{array}$ & 3.8 & 3.3 & 2.4 & 6.4 & 1.3 & 2.6 \\
\hline $\begin{array}{l}\text { Frequency } \\
\lambda_{c}\end{array}$ & 0.1 & 0.2 & 0.2 & 0.1 & 0.4 & 0.2 \\
\hline $\begin{array}{l}\text { Damping } \\
\text { factor } \rho\end{array}$ & 0.9 & 0.8 & 0.9 & 0.9 & 0.8 & 0.9 \\
\hline
\end{tabular}

Cattle

Brazil Chile Uruguay

Source: Authors.

Table 2 shows that the period of the pig cycle has been estimated to vary between 2.4 years in Uruguay and 3.8 years in Brazil. Chile is found to have a pig cycle of 3.3 years. These cycle periods coincide with three pig production cycles of 10 months or two complete pig production cycles of 18 months as depicted in Figure 5. PIC (2012) include the gestation, birth and growth of female piglets, followed by the sexual maturity and insemination of the sows, and then adding the time required by the farrow to achieve the slaughter weight.

The cattle cycles are found to have a period between 1.3 years for Chile and 6.4 years for Brazil. This means, e.g., that in the case of the Uruguayan cattle cycle, the amount of cattle supplied by the producers leads to a peak or a trough every 2.6 years as illustrated in Figure 7 . This result is in line with the time elapsed between producers' decisions to increase production and

\footnotetext{
${ }^{13}$ The relative cycle amplitude is calculated as the division of the cycle amplitude by the corresponding observation mean price.
} 
slaughter weight as indicated in Figure 5. Brazil and Uruguay exhibit the highest damping factor in the pig sector, followed by Chile with a smoother cycle having a damping factor of $0.8{ }^{14}$

Figure 6 shows the estimated cycles of pig prices. The Uruguayan and Chilean cycles coincide in ascending and descending cycle phases in the periods from 1997 to 1998, 2003 to 2005, and 2006 to 2007. The Brazilian cycle is smoother and has an ascending and descending phase from, for example, 2003 to 2005 . The relative cycle amplitude is larger for Chile than for Uruguay and Brazil.

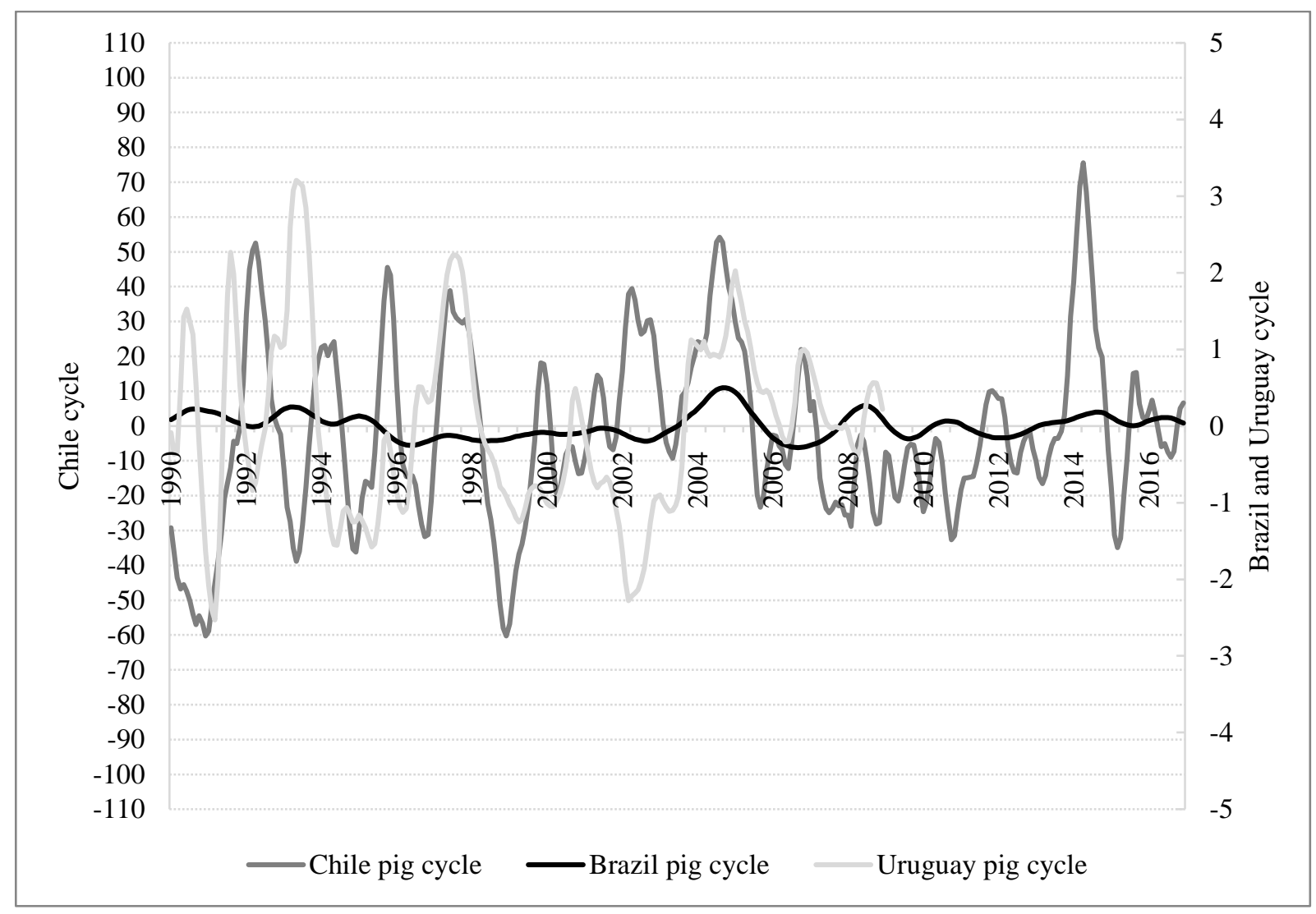

Figure 6 Estimated cycles of pig prices by country, 1990-2016

Source: Authors.

Since 1993, the development of Uruguay's and Chile's cattle price cycles largely coincides showing peaks and troughs often in similar periods (Figure 7). As in Figure 6, the Chilean price cycle appears to have the highest relative amplitude (Table 2) having for cattle also by far the shortest period of the three countries considered.

${ }^{14} \mathrm{~A}$ model with a damping factor less than 1 is a stationary stochastic process. 


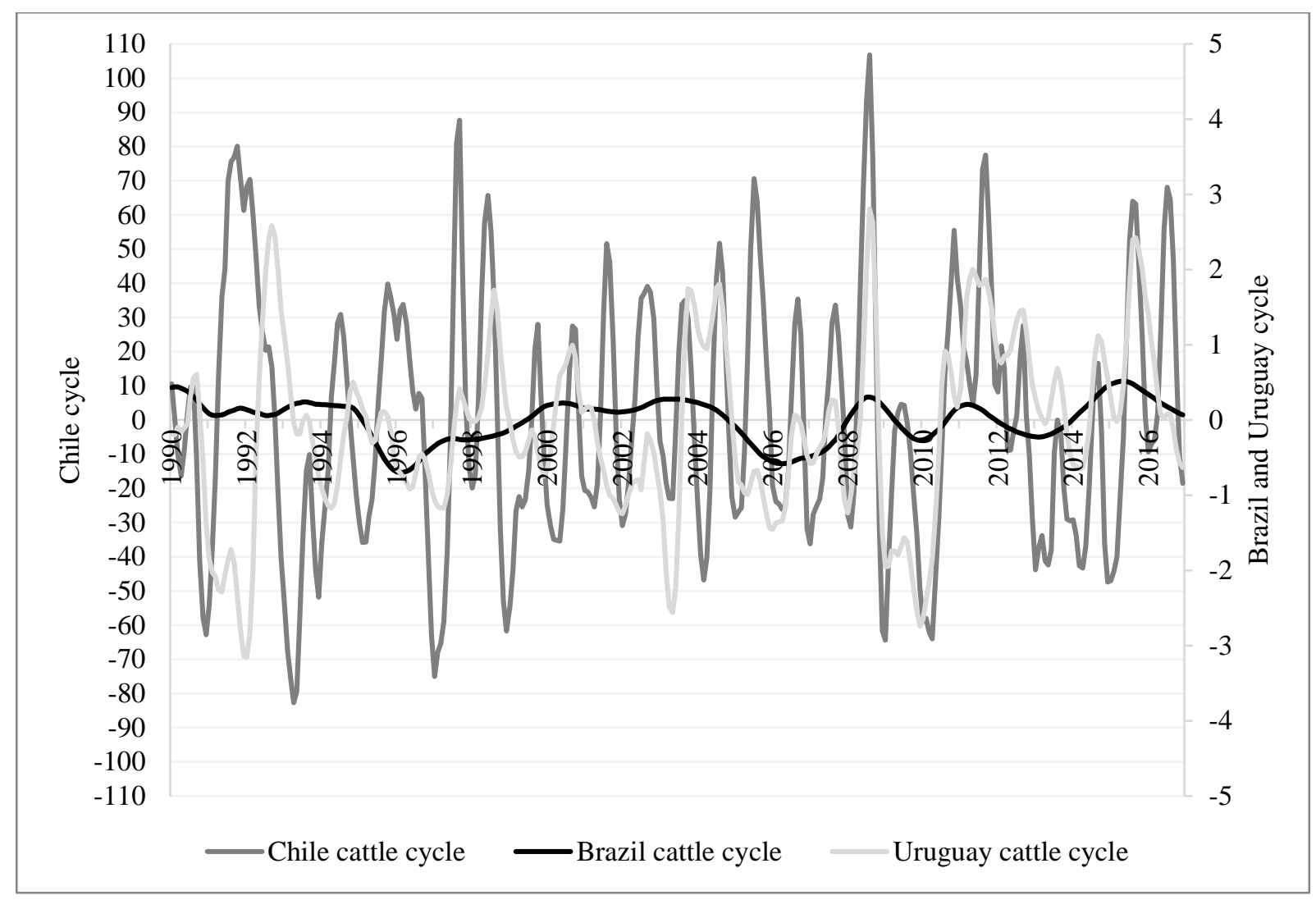

\section{Figure 7 Estimated cycles of cattle prices by country, 1990-2016}

Source: Authors.

\subsection{Discussion and conclusions}

The concept of price cycles in the context of agriculture refers to periodic price fluctuations around the long-run trend lasting more than one year. Such cycles may arise due to changes in demand or temporal delays necessary for the adaptation of quantities supplied by farmers. Thus, biological characteristics of production are a crucial factor influencing cycle duration. The time required for supply in the cattle and pig sectors to respond to price increases by herd size expansion is typically about 4.5 years and 1.5 years, respectively.

Our literature review indicates that the presence of price cycles has been studied for a number of countries. Although South America has a prominent role in global meat production, there has been little evidence on cattle and pork price cycles in this region. Thus, this analysis contributes to the literature by providing comprehensive up-to-date evidence on cycles in pig and cattle prices in three South American countries. The Kalman filter is used to estimate univariate state-space models, which are selected based on a transparent and reproducible structural model selection process seeking to identify meaningful and interpretable model specifications that exhibit ideal residual characteristics and are optimal regarding model selection criteria. 
The pig price cycles of all three countries are estimated to have lengths varying between three and four years being in line with the results in the literature. This duration coincides with about two complete agronomic pork production cycles of 18 months. The cattle cycle lengths of Brazil, Chile and Uruguay are estimated to have durations of 1.3 to 6.4 years, being shorter than the 10 year cycles often found in the literature, but roughly in line with the biological reproduction cycles of cattle production taking three to four years.

Price cycles are found to be least pronounced in terms of duration and amplitude in Brazil while absolute and relative amplitudes in Uruguay and Chile appeared to be considerably higher and durations much shorter. The high frequency and relative amplitude of cycles of Chilean pig and cattle prices in comparison to Brazil and Uruguay indicate that in Chile, farm-gate prices tend to strongly and quickly fluctuate around their long-run trend developments. In other words, Chilean producers face a higher price uncertainty around the long-run price trends than producers in Uruguay and Brazil.

Our analysis contributes to the literature by isolating price cycles in the South American context and providing up-to-date measurements of their statistical characteristics. The short durations of cattle price cycles in South America as estimated above seems to be a particularity for these Southern American countries. This research can be extended by identifying most relevant determinants and quantifying their partial effects on cycle patterns. This may clarify to what extent supplied quantities of meat in these countries have been changing periodically. Combinations of the further factors - some of them mentioned above - can be assessed to what extent they are determining cycle developments. Future research might also extend the analysis to price cycles in Argentina given that it is a large global beef producer if sufficient data become available, or assess cycle spillovers between these neighboring countries.

The analysis of agricultural price cycles, as presented in this paper, sheds light on crucial aspects of price dynamics. Identifying such cycles or predicting them for the immediate future can greatly assist producers in their production decisions. This knowledge also provides insight to policy makers into the width and the speed of the regular price fluctuations around the longrun trend. It helps in understanding whether and in which position a cycle currently is and when there will be a need for support policies - whatever forms such support might take - during the troughs of the cycles. Based on such knowledge, policy makers are enabled to set up policies for the purpose of extending price cycle durations or attenuating cycle amplitudes. 


\section{Chapter 4 The synchronization of cycles in pig and cattle prices between Brazil, Chile and Uruguay $^{15}$}

Autoren: Astrid Fliessbach and Rico Ihle

Keywords: cattle cycle, concordance index, Latin America, pig cycle, pork cycle, price comovement

\subsection{Introduction}

Barely a decade ago, in 2007/2008 and to a somewhat lesser extent in 2011/2012, governments as well as international institutions and stakeholders of global food markets have witnessed a massive synchronized price rise for many food commodities at the global level which has highlighted the fragility of the global food situation (The Economist, 2007; FAO, WFP and IFAD, 2011). International food price increases have brought significant hardships to populations in many countries who spend large shares of their budgets on staple foods (Abbott, 2009). Food price movements had different effects on different countries, often the poorest being most affected (Subervie, 2008).

Several publications analyzing threats to global crop production and food security name synchronization as a central issue. Mehrabi and Ramankutty (2019) show that increasing synchronization between crops production cycles make global calorie production more unstable. Tigchelaar et al. (2018) forecast rising instability in global grain trade and international grain prices. Anderson et al. (2019) find that global synchronous crop failures, caused by climate patterns such as El Niño Southern Oscillation (ENSO), pose substantial risks to global food security. Homer-Dixon et al. (2015) study how simultaneous shifts in several social-ecological systems might potentially interact to cause an inter-systemic crisis and how such a crisis could rapidly spread at a global level.

The extent of synchronous price developments witnessed in 2007/2008 resulted in a wave of short-term political decisions in many countries to cope with the results (e.g., Schüttel et al.

\footnotetext{
${ }^{15}$ This chapter has made few changes to the paper "The synchronization of cycles in pig and cattle prices between Brazil, Chile and Uruguay" submitted to Agricultural Economics (AGECON).
} 
2011). FAO, WFP and IFAD (2011) stress that the exports restrictions of some countries exacerbated price increases in international markets and compounded the impacts of food shortages in import-dependent countries. As the synchronization of prices - being a variable setting crucial economic incentives - might result in threats to food security as price developments might become magnified by moving in parallel across countries and commodities, an objective measurement and a better understanding of synchronization would facilitate developing policy responses to prevent such synchronization. Nevertheless, the agricultural economics literature barely provides quantitative measurements of the synchronization of food prices.

In contrast to Baffes and Haniotis (2016) who analyze drivers of price movements, this article focuses on the quantitative measurement of the synchronization of agricultural prices. In particular, we focus on prices of raw products produced by agriculture. Murphy (1999) characterizes the synchronization of the cycles of various prices as regular waves observable in each price series which reach their troughs and peaks, that is, their turning points at about the same time. Harding and Pagan (2002; 2006) define synchronization between two or more cycles of economic variables in general as the fraction of observed time periods during which both cycles change simultaneously in the same direction.

We focus on prices of pigs and cattle as meat-based food is currently receiving substantial media attention in the context of the societal discourse on climate change. As meat production as well as consumption play important roles in Latin America (OECD and FAO, 2018), we focus on this region. We measure to what extent the cycle components of cattle and pig prices of Brazil, Chile and Uruguay are synchronized with each other. Using the filters of Kalman (1960) and Hodrick and Prescott (1997), we extract the cycle components from the price series. We measure synchronization in a bivariate as well as a multivariate form using the concordance index developed by Harding and Pagan (2002 and 2006). This approach has - to the best of our knowledge - not yet been used to analyse synchronization of agriculture price cycles. This index is applied as an average characteristic of two or more time series and in a rolling window version in order to be able to evaluate the stability of synchronization through subsequent ranges of periods.

The remainder of this chapter is structured as follows. Section 4.2 gives an overview of empirical studies measuring synchronization of economic variables. Section 4.3 elaborates on the methodological background for measuring synchronization. Section 4.4 provides a review of the main factors identified by the existing literature which affect the synchronization of 
business cycles, financial cycles and cycles of agricultural prices. The synchronization measurement via concordance indices and the specific approach implemented in our empirical analysis are outlined in Section 4.5. Section 4.6 presents the data before the results of our empirical analysis are presented in Section 4.7. Section 4.8 summarizes the main results, relates them to existing literature and concludes.

\subsection{Overview of price cycle synchronization literature}

We conducted a comprehensive review of empirical studies measuring synchronization of economic variables details of which are shown in Table A.9 in the appendix. This review of the current literature on synchronization shows that this topic is most frequently analyzed in the context of business cycle analysis. About $80 \%$ of the thirty-seven papers identified in Table A.9 inspecting cycle synchronization concentrate on business cycles. Three papers analyze stock market cycle synchronization, and two papers housing prices synchronization. We found only single papers assessing synchronization of agricultural prices, mineral commodities prices, per capita income and prices in newspaper markets which highlights the gap in the analysis of the synchronization of agricultural prices.

The majority of papers (89\%) confirms synchronization; only one paper did not find synchronization and four papers report decreasing synchronization. One paper finds weak evidence for synchronization in industrial production and strong synchronization in stock prices. Table A.9 shows that the papers reviewed use various approaches to quantify synchronization. $57 \%$ of the papers use a correlation index. A quarter of these papers use the concordance index of Harding and Pagan (2002; 2006). Five of the publications are based on structural time series analysis. The duration of the time window investigated by half of the papers ranges from 20 to 40 years. Ten papers used a period of up to 20 years, four from 41 to 60 years and three longer than 61 years. The regions most often analyzed are EU and OECD countries (Table A.9).

\subsection{Defining synchronization of price cycles}

Price cycles are fluctuations of price time series taking place in a middle-run with a typical duration of lasting more than one year (Koester, 2010). Cycles have the ideal shape of an expansion phase during which the magnitude of the underlying variable consecutively increases and which finishes with a turning point of the direction of the consecutive movement in the form of a peak. This is followed by a contraction phase during which the magnitude of the underlying variable consecutively decreases finishing with the next turning point in the form of a trough, and afterwards a new expansion phase starts. Hence, an expansion phase is the period 
from a trough to a peak, and a contraction as the period from a peak to a trough. A single cycle is usually understood as the movement from peak to peak or trough to trough as displayed in Figure 8.

Two or more cycles are seen as synchronized if their turning points occur at either roughly the same points in time or differ by intervals that are roughly constant, that is, that the turning points “cluster together'”(Harding and Pagan, 2006). Such an understanding of synchronization measures the extent to which price series or single components therefrom exhibit a largely identical path, or more simply, to what extent two or more time series display co-movements. It does not try to explain reasons for the partially observed co-movements, nor does it allow the drawing causal inference. However, objective and precise measurement is the precondition for developing future analysis into these directional movements.

In order to measure cycle synchronization between two (or more) series $y_{j}$ and $y_{r}$, the direction of changes of each between two periods has to be mapped. We follow Harding and Pagan (2002) by denoting this indicator variable for series $y$ in period $t$ as $S_{y t}$. If series $y$ values increased from the past to the current period, then $S_{y t}=1$ indicates expansion. If they decreased or stagnated, then $S_{y t}=0$ indicates contraction or stagnation as summarized in (5):

$$
S_{t}=\left\{\begin{array}{l}
0 \text { if } y_{t}-y_{t-1} \leq 0 \text { (contraction or stagnation) } \\
1 \text { if } y_{t}-y_{t-1}>0 \text { (expansion) }
\end{array}\right.
$$

Harding and Pagan (2006) suggest measuring synchronization between all series of interest by the share of periods during which all series of interest co-move; when they are simultaneously in a state of expansion or contraction. From this basis, the following stylized cases can be distinguished. Panel I in Figure 8 shows strong perfect positive synchronization (SPPS). This is the case if two or more cycles are simultaneously in expansion and contraction in all periods observed, in other words $S_{j t}$ and $S_{r t}$ are identical for all $t$. The case of strong perfect negative synchronization (SPNS) is shown in panel II of Figure 8: the two cycles are in all periods in exactly the opposite phase. Harding and Pagan (2006) also mention strong non-synchronization (SNS) as the third stylized case. As visible in panel III, this refers to the case when no simultaneous or opposite patterns are observable, that is, both cycles move independently. 


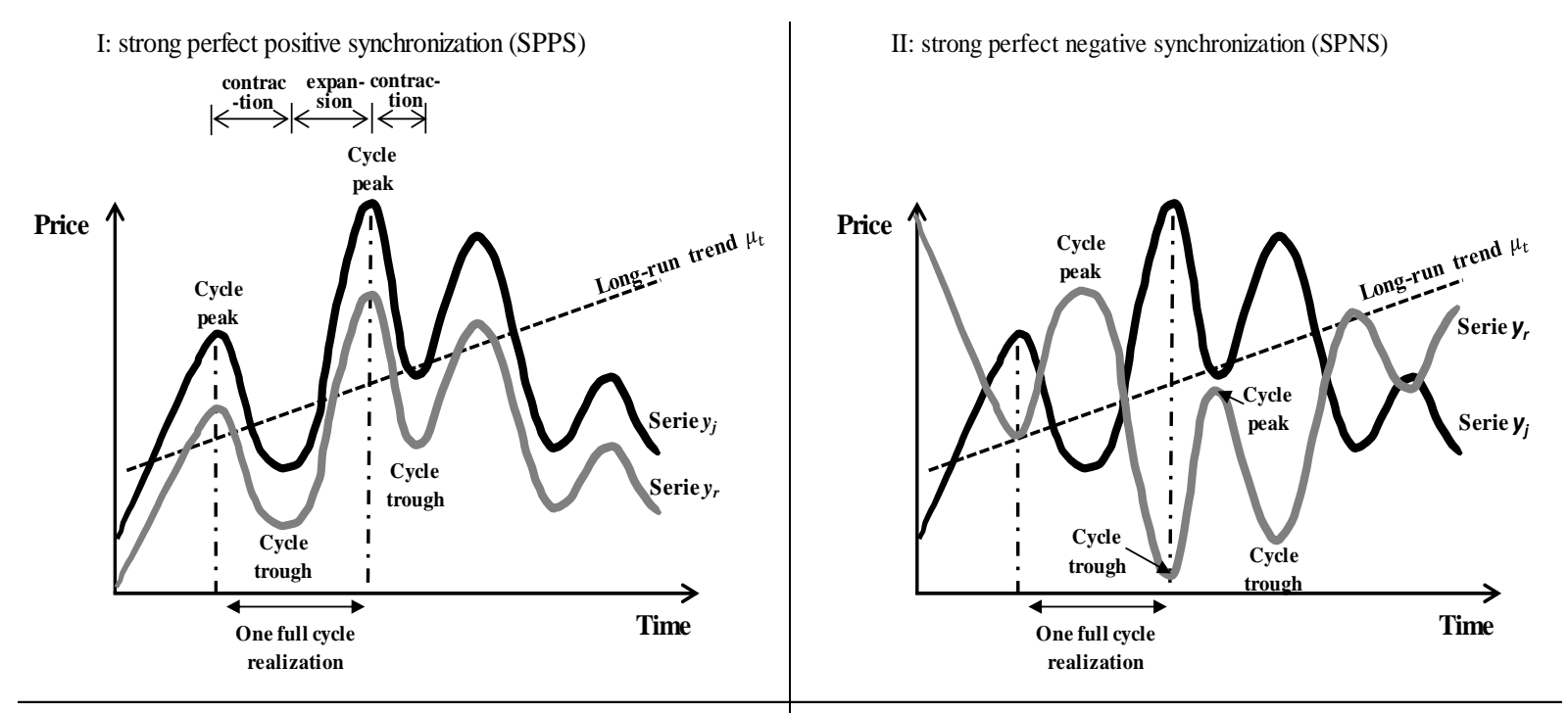

III: strongly non-synchronized (SNS)

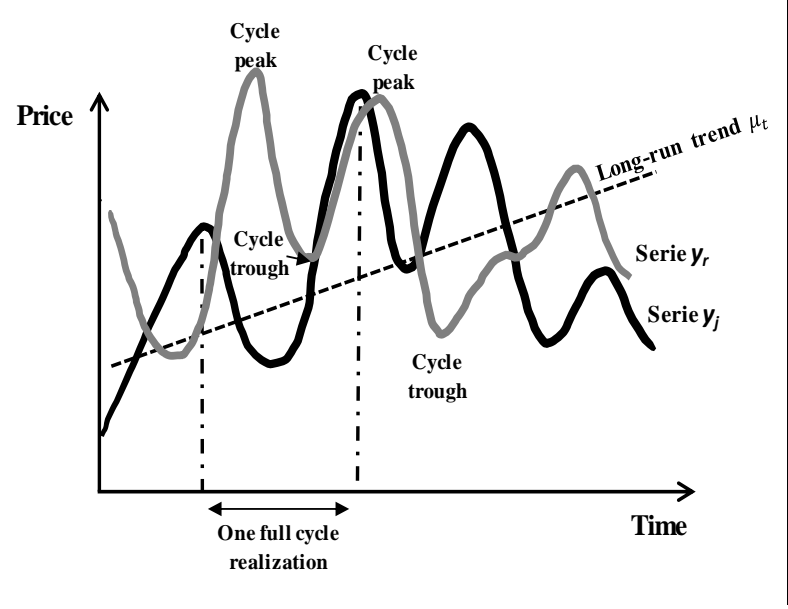

Figure 8 Forms of synchronization

Source: Authors based on Harding and Pagan (2006).

\subsection{Determinants of synchronization}

Synchronization of time series has mainly been assessed in the contexts of business cycle and financial cycle analysis. For the analysis of patterns in agricultural or food prices, the approach outlined in Section 4.3 has not yet been used to the best of our knowledge. This section includes the main determinants of business and financial cycles; there was no information found for the determinants of agriculture price cycles. Therefore, we include the main factors affecting the price spikes in 2007/2008.

\subsubsection{Determinants of synchronized business cycles}

Business cycle synchronization between countries provides information on whether countries experience the same macro-economic conditions. Fiess (2007) argues that the degree of business cycle synchronization and the synchronized reaction of national economies to common 
shocks determines which fiscal and monetary policy should be employed by governments. Frankel and Rose (1998), Imbs (2004) and Calderón et al. (2007), estimate a strong and robust positive relationship between trade and business cycle synchronization. Another factor causing business cycles to become synchronized is similarity in industrial structures. This linkage has been stressed in a series of papers by Imbs (1998; 2004; 2006). A third variable studied by Rose and Engel (2002) is currency unions. Jansen and Stokman (2014) point out that more synchronized business cycles are associated with stronger foreign direct investment relations in the period 1995 to 2011.

\subsubsection{Determinants of synchronized financial cycles}

Huang et al. (2016) point out that synchronization is also a common behaviour in financial markets, as they are very sensitive to economic instabilities. Trade and financial integration contribute positively to stock market synchronization (Waelti, 2005). Other factors such as the similarity of economic institutions between countries, informational symmetries and a common language also contribute to stock market synchronization (Waelti, 2005).

Another factor that increases stock market cycle synchronization is the financial liberalization in the nineties. Afef (2014) found synchronization in stock markets of 70 percent between the United States and developing countries after financial liberalization.

\subsubsection{Determinants of synchronized agricultural prices}

Based on the law of one price, international trade and the removal of trade barriers are some possible factors affecting synchronization of agricultural price cycles. The law of one price states that prices of an identical commodity or asset traded in different geographic markets under competitive market conditions are uniform, after accounting for costs of adding place, time, and value to products within the market. The law of one price results from the profitseeking behavior of food marketing firms and traders (Kohls and Uhl, 1990).

According to Wiggins et al. (2010), the main factors affecting synchronized price increases in 2007/2008 on the supply side were: poor harvests, especially of wheat; lower grain stocks; and a rise in oil prices. On the demand side influences included: widespread inflation resulting from rapid growth of the world economy; policies such as export bans and restrictions, restocking in tight markets and reduced import tariffs; and depreciation of the USA dollar.

\subsection{Measurement of cycle synchronization}

This section describes the methodology used to measure synchronization between the cycles of Brazilian, Chilean and Uruguayan pig and cattle producer prices. As a first step, the cycle 
components of a price time series need to be isolated for which we use the Kalman filter. Subsequently, we quantify synchronization using both the bivariate and multivariate concordance index as developed by Harding and Pagan (2002). The last subsection outlines the exact details of our empirical approach applied for characterizing synchronization.

\subsubsection{Isolating and measuring price cycles}

Price time series are often described to consist of a number of unobserved components. In order to analyse price cycles, it is necessary to make them visible, disaggregating the subsequently observed price data into a trend, seasonality, cycle and white noise component.

The extraction of price cycles can be done by filtering a price series. In the literature, a number of filters have been suggested. We apply the filter suggested by Kalman (1960), which is a recursive process that produces estimates of the unobserved components. The Kalman filter minimizes the mean squared error of the estimated parameters and produced optimal estimates if the Gaussian properties hold.

\subsubsection{Measuring synchronization by the bivariate concordance index}

The bivariate concordance index developed by Harding and Pagan $(2002 ; 2006)$ measures the fraction of the observed periods two cycles are simultaneously located in the same phase of their development as described in Section 4.3. That is, it measures the number of periods they are moving in the same direction: simultaneously in the same state of expansion $\left(S_{t}=1\right)$ or contraction $\left(S_{t}=0\right)$

For the purpose of measuring cycle synchronization between two (or more) cycles $c_{j}$ and $c_{r}$, the changes between two periods $\left(S_{j t}\right.$ and $S_{r t}$ ) has to be inspected. Thus, synchronization is given a notation of $S_{t}=1$ if the cycle is in an expansion phase, or the value $S_{t}=0$ if the cycle is in a stagnant or contraction phase.

After the cycle components have been isolated, the concordance index $I_{j r}$ between the cycle components of the two times series $y_{j}$ and $y_{r}$ can be calculated as in (6):

$$
I_{j r}=\frac{1}{T}\left[\sum_{t=1}^{T}\left(S_{j t} * S_{r t}\right)+\left(1-S_{j t}\right)\left(1-S_{r t}\right)\right]
$$

The product of the changes $S_{j t}$ and $S_{r t}$ equals unity if both cycle components simultaneously increase (expansion). Simultaneous contraction exists when the product of $\left(1-S_{j t}\right)$ and $\left(1-S_{r t}\right)$ equals unity. ${ }^{16}$ This definition implies that if the two series are perfectly

\footnotetext{
${ }^{16}$ See appendix A.4 for more details.
} 
positively synchronized (SPPS, see panel I in Figure 8), (perfect negatively synchronized (SPNS, see panel II in Figure 8), the concordance index has a maximum (minimum) value of unity (zero) as for all periods $T S_{j t}=S_{r t}\left(S_{j t}=1-S_{r t}\right)$. The empirically observed synchronization will most often lie somewhere in between these two extremes. In general, $S_{t}$ is a high order stationary and ergodic Markov chain (Harding and Pagan, 2006).

The necessary and sufficient condition for strong perfect positive synchronization (SPPS) is that the probability of cycle $c_{j}$ of series $y_{j}$ being in expansion, while cycle $c_{r}$ of series $y_{r}$ being in contraction in the same period $t$ equals zero:

$$
\begin{aligned}
& \text { (I) } \quad \operatorname{Pr}\left(S_{j t}=1, S_{r t}=0\right)=0, \\
& \text { (II) } \quad \operatorname{Pr}\left(S_{j t}=0, S_{r t}=1\right)=0 .
\end{aligned}
$$

In the same way, strong perfect negative synchronization (SPNS, panel II in Figure 8) will occur when the probability of cycle $c_{j}$ of series $y_{j}$ being in contraction and of cycle $c_{r}$ of series $y_{r}$ being in expansion in the same period $t$ equals unity:

(III) $\operatorname{Pr}\left(S_{j t}=0, S_{r t}=1\right)=1$,

(IV) $\operatorname{Pr}\left(S_{j t}=1, S_{r t}=0\right)=1$.

Cycles that are strongly non-synchronized (SNS, panel III in Figure 8), may then be regarded as the case when $S_{y t}$ and $S_{r t}$ are equally likely to be in the same phase or in the opposite phase.

\subsubsection{Multivariate concordance index}

The multivariate concordance index corresponds to the general case where there are cycle components of $n$ series $y_{1 t}, \ldots, y_{N t}$ each having a state indicator $S_{n t}, n=1, \ldots, N$. Similar to the bivariate concordance index, the product of the change indicators $S_{1 t}, \ldots, S_{N t} /$ $\left(1-S_{1 t}\right), \ldots,\left(1-S_{N t}\right)$ measures simultaneous expansion/ contraction for all cycles considered. The multivariate concordance index $I_{N}$ is thus calculated as in (7):

$$
I_{N}=\frac{1}{T}\left[\sum_{t=1}^{T}\left(S_{1 t} * S_{2 t} * \ldots * S_{n t}\right)+\left(1-S_{1 t}\right)\left(1-S_{2 t}\right) \ldots\left(1-S_{n t}\right)\right]
$$

\subsubsection{Empirical approach}

In order to answer the research question, we isolate pig and cattle price cycles in Brazil, Chile and Uruguay using the Kalman filter. We consider a filter specification of a deterministic linear trend model with fixed drift, that is a slope term in the long-run trend, including a stochastic cycle and seasonality. 
After isolating the cycle components, we translate them into bivariate and multivariate concordance indices as described above according to (6) and (7). It is first necessary to map the cycles into the change indicator variable between two subsequent periods as outlined in (5). Thus, $S_{t}=1\left(S_{t}=0\right)$ denotes that a cycle is in an ascending (descending) movement. As any concordance index provides an aggregated measure of synchronization during all time periods $T$ considered, we assess global synchronization for all periods observed in addition to temporal stability of synchronization by applying a moving-window version of the index to subsequent subsets of the entire observation period.

We first analyse the bivariate synchronization, bivariate global concordance index, between pig price cycles for Brazil (BP) and Chile (CP); Brazil (BP) and Uruguay (UP) as well as Chile (CP) and Uruguay (UP). ${ }^{17}$ We also analyze the synchronization between pig and cattle of price cycles in each country. We also apply the multivariate global concordance index (7) for analyzing synchronization between more than two cycles. Thus, we assess trivariate synchronization between BP, CP and UP as well as between BC, CC and UC using (8). Results are reported in Section 4.7.

$$
I_{3}=\frac{1}{T}\left[\sum_{t=1}^{T}\left(S_{B, t} * S_{C, t} * S_{U, t}\right)+\left(1-S_{B, t}\right)\left(1-S_{C, t}\right)\left(1-S_{U, t}\right)\right]
$$

The rolling window concordance index has the advantage that it shows the development of synchronization over a fixed time window over time. Thus, it allows for comparisons with the global concordance index, which provides the aggregate synchronization estimate over the total observation period.

The bivariate rolling window concordance indices are calculated according to (9):

$$
I_{j r}^{\theta_{t}}=\frac{1}{\Omega}\left[\sum_{\theta_{t}=1}^{\theta_{t}+\Omega}\left(S_{j \theta_{t}} * S_{r \theta_{t}}\right)+\left(1-S_{j \theta_{t}}\right)\left(1-S_{r \theta_{t}}\right)\right] \text { where } \theta_{t}=\{1, \ldots, T-\Omega\}
$$

We choose $\Omega$, the length of the time window, to be 60 months (five years). $\theta_{t}$ denotes the index within each window. For example, the first window consisting of 60 observations January 1990 to December 1994, the second window covers February 1990 to January 1995, and the last of the 265 calculated windows covers January 2011 to December 2016. The rolling multivariate concordance index is calculated correspondingly.

For robustness, we also isolate the cycle components based on the Hodrick-Prescott filter (Hodrick and Prescott, 1997). Using a bivariate global and bivariate rolling window

\footnotetext{
${ }^{17}$ For the cattle price cycles, similar symbols apply Brazil (BC) and Chile (CC); Brazil (BC) and Uruguay (UC) as well as Chile (CC) and Uruguay (UC).
} 
concordance index, we provide evidence in appendix A.6 of whether the extracted cycles of the both filters are reasonably similar and consistent.

We proceed with the analysis measuring selected aspects of synchronization stability between two or more cycles based on the Kalman filter extractions. In particular, we provide evidence on the magnitude of instable synchronization, as well as on the duration of phases which have temporally higher and lower synchronization than the global aggregate.

We assess stability of synchronization using a mean squared error (MSE) type measure calculated between the rolling window indices and the global index as:

$$
M S E=\frac{1}{n} \sum_{t=1}^{n}\left(I_{j r_{t}}-I_{j r_{t}}^{\theta_{t}}\right)^{2}
$$

Where $I_{j r}$ is the global index between cycle $c_{j}$ of series $y_{j}$ and of cycle $c_{r}$ of series $y_{r}, I_{j r}^{\theta_{t}}$ the rolling window index between and cycle $c_{j}$ and cycle $c_{r}$, and $n$ the total number of concordance indices considered for the MSE (10) calculation. MSE measures how close the bivariate rolling window concordance index is to the bivariate global concordance index over all observation periods. For every observation period, the vertical distance between the estimate of the bivariate rolling window concordance index to the corresponding estimate of the bivariate global concordance index is squared. All squared deviations are added up and divided by the number of total periods. The smaller the resulting measure (10), the more stable the synchronization.

In order to characterize the length of the synchronization deviation, deviation between the rolling window concordance index and global concordance index, we count the number of months in which the bivariate rolling window concordance index moves above and below the bivariate global concordance index line. Results are shown in Section 4.7.2.

Next, we test synchronization stability by applying F tests to ascertain whether the rolling window estimates significantly differ from the stable global estimates. That is, to test whether the rolling window estimates are nested in the global concordance estimate. We approximate the rolling window estimates by the following increasingly complex parametric time polynomials:

$$
\begin{aligned}
& M 1: y=\beta_{0}, \\
& M 2: y=\beta_{0}+\beta_{1} t \\
& M 3: y=\beta_{0}+\beta_{1} t+\beta_{2} t^{2} \text { and } \\
& M 4: y=\beta_{0}+\beta_{1} t+\beta_{2} t^{2}+\beta_{3} t^{3}
\end{aligned}
$$


Model $M 1$ correspond hypothesizes a constant function, i.e. stable synchronization as in the case of the bivariate and trivariate global concordance indices. Model M2 (12) allows for synchronization with a constant marginal increase (slope). Models M3 (13) and M4 (14) hypothesize synchronization to follow a time polynomial of second and third order respectively, exhibiting unstable synchronization.

We select a suitable model from among $M 2, M 3$ and $M 4$, that with the best fit to the different rolling window concordance curves obtained based on Akaike's Information Criterion (AIC; Akaike, 1974). An F test is then applied to the chosen model to check whether it is consistent with specification $M 1$. Such a test allows an examination as to whether the rolling window concordance curves are more consistent with stable synchronization as in $M 1$ or unstable synchronization as in $M 2$ to $M 4$. Thus, the null hypothesis is stable synchronisation while the alternative is unstable synchronisation.

$$
\begin{array}{ll}
\mathrm{H}_{0}: \beta_{1}=\beta_{2}=\beta_{3}=0 & \text { (stable synchronization) } \\
\mathrm{H}_{1}: \beta_{1} \text { or } \beta_{2} \text { or } \beta_{3} \neq 0 & \text { (unstable synchronization) }
\end{array}
$$

Results are reported in Section 4.7.3.

\subsection{Data}

We use monthly farm-gate prices of pig and cattle in Brazil, Chile and Uruguay, between January 1990 to December $2016 .{ }^{18}$ Table A.5 in the appendix gives an overview of the data sources, exact descriptions of the types of prices used as well as their currencies. This data are based on nominal, monthly farm-gate selling prices of live animals. The raw data have been transformed into real prices in national currency using domestic CPIs with a base of January 2001.

As the data are in national currencies, the real prices have differing units and are difficult to compare, thus we analyze indexed prices. The indexed prices (15) represent the percentage deviation of each real price in the respective national currency for each month relative to its respective mean, which is calculated as follows:

$$
\text { price index }=\frac{\text { real price }}{\text { mean }}
$$

\footnotetext{
18 This analysis does not include Argentina being one of the main meat producers in Latin America as it was impossible to obtain a sufficiently long time series of cattle and pig producer prices. Future research might try to include Argentina in further studies if suitable data becomes available.
} 
This approach has the advantage that the magnitudes of the price cycles are measured in relative terms to the mean of each series.

Table A.10 in the appendix summarizes the descriptive statistics of the data. For each series, means and medians are almost equal, pointing to an un-skewed distribution of prices. The coefficient of variation (CV) is 0.3 of pig producer prices in Brazil and 0.2 for Chile and Uruguay. The $\mathrm{CV}$ of cattle prices of all three countries is 0.2 , indicating a similar degree of relative dispersion for all three cases.

\subsection{Results}

After applying the Kalman filter to the constructed price indices of real farm-gate prices for pig and cattle in Brazil, Chile and Uruguay, we measure synchronization of the isolated price cycles shown in Figure 9 and $10 .{ }^{19}$

Figure 9 illustrates that all three countries experienced highly synchronized developments of pig price cycles from 1990 up to 2003. After 2003, the Brazilian cycle shows widest amplitude, the Uruguayan one a sustained increase and the Chilean one the most stable amplitude until 2013.

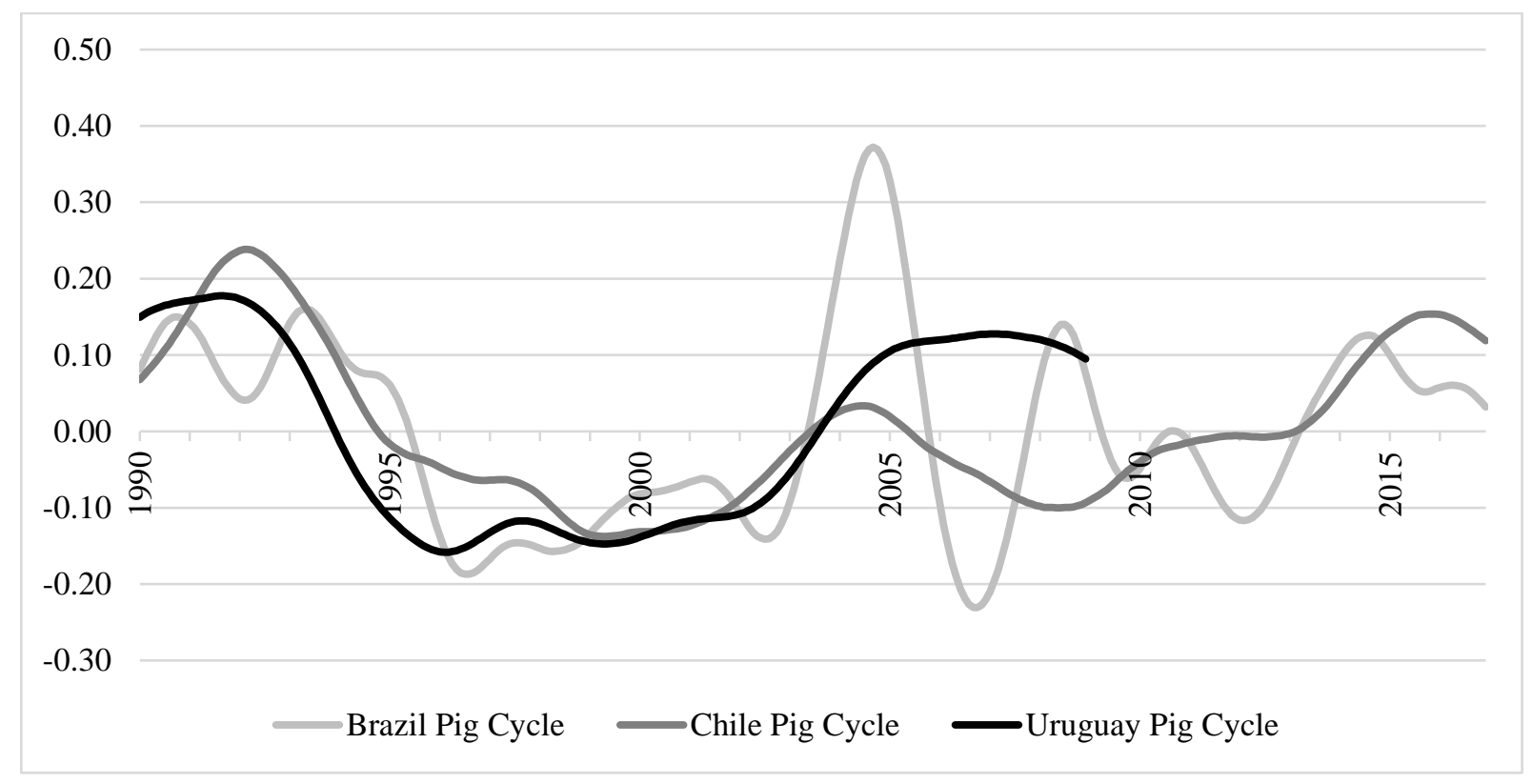

Figure 9 Cycles in pig prices in Brazil, Chile and Uruguay

Source: Authors.

\footnotetext{
${ }^{19}$ See appendix A.5 for cycles isolated using the Hodrick-Prescott filter Figure A.8 to A.9.
} 
The cattle price cycles, Figure 10, of Brazil, Chile and Uruguay show much less synchronized movements. The declines and increases of the cycles start in differing years (or not all) and positive and negative fluctuations are exhibited in all three cycles.

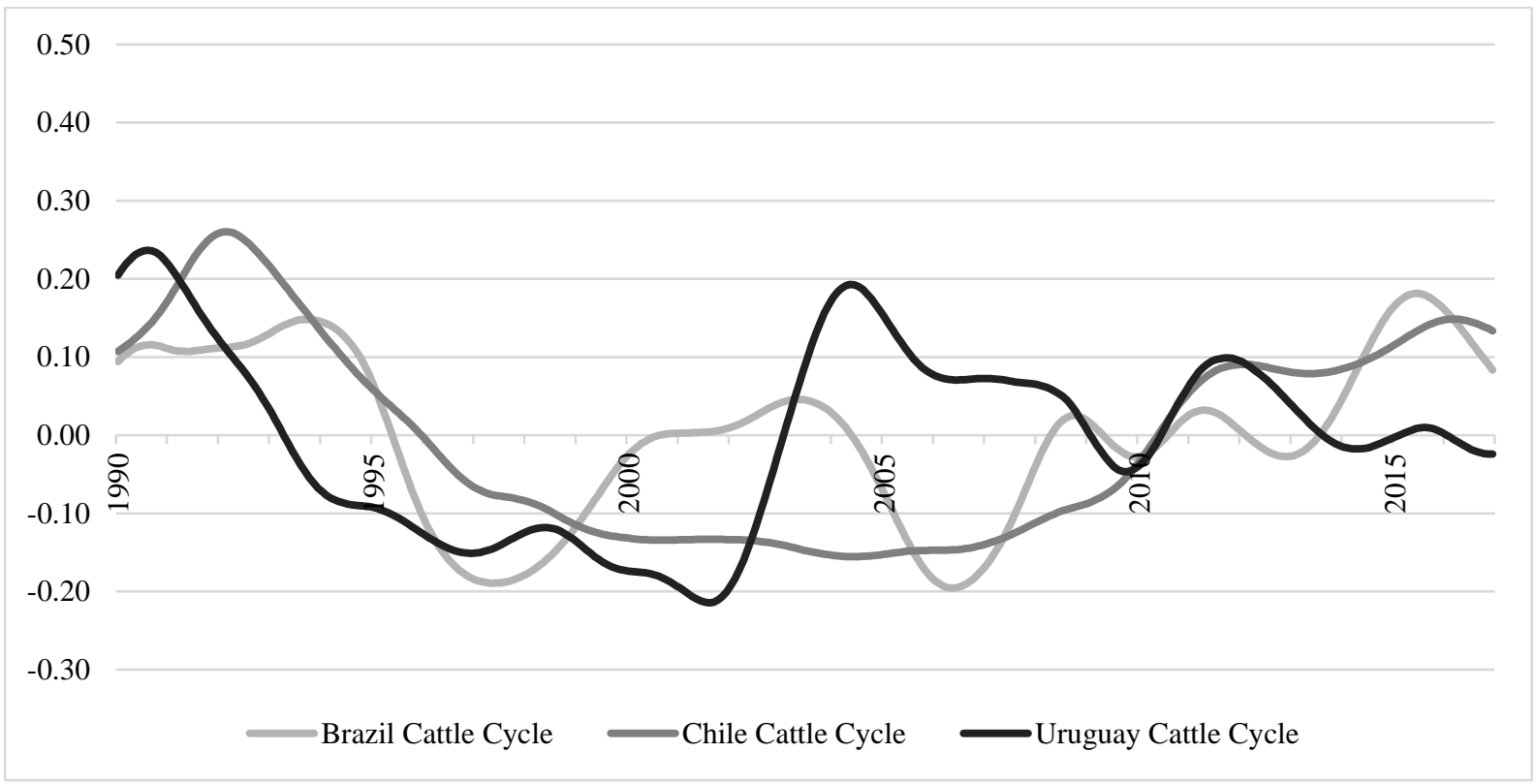

Figure 10 Cycles in cattle prices in Brazil, Chile and Uruguay

Source: Authors.

Although visual inspection gives an initial rough impression of the synchronization of cycles of pig and cattle prices in these three countries and its temporal stability, visual inspection is a very imprecise and subjective measurement. Therefore, we proceed with an objective quantification of the synchronization of the extracted price cycles in the remainder of this section.

\subsubsection{Global concordance indices}

The bivariate global concordance index in Table 3 suggests that between $50 \%$ and $74 \%$ of the observed months, at least two cycles move in the same direction. The highest synchronization of $74 \%$ is found between the cycles of pig prices of Chile and Uruguay, and the lowest between the cattle price cycles of Chile and Uruguay (50\%). These bivariate index estimates confirm the visual impression from Figure 9 and 10: the three pairs of cattle price cycles rank among the pairs showing lowest synchronization $(58 \%, 54 \%$ and $50 \%)$. Intra-country synchronization of the pig and cattle price cycles show the highest synchronization levels of over $60 \%$. 
Table $3 \mathrm{Bi}$ - and trivariate concordance indices of cycle synchronization

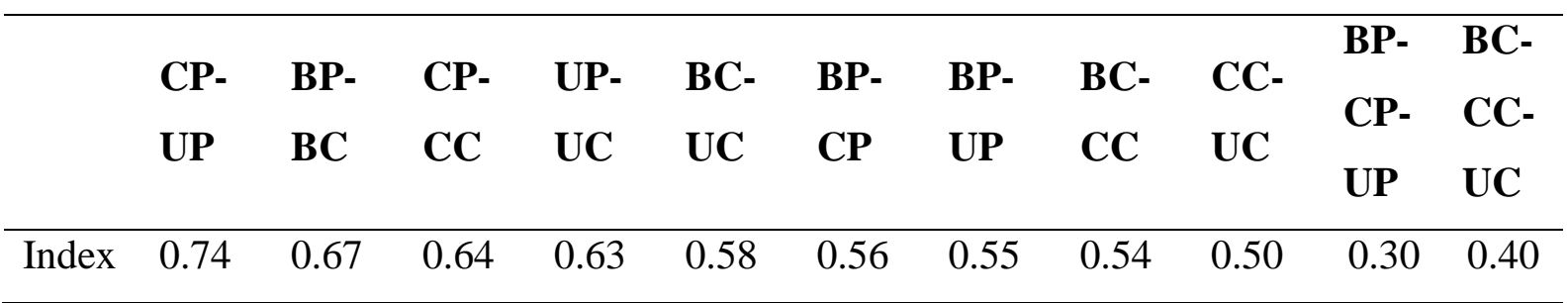

Source: Authors.

The global concordance index between the pig (cattle) price cycles of all three countries is $30 \%$ (40\%), meaning that all three cycles move in 68 months (130 months) in to the same direction. This gives pig (cattle) farmers during these months the same indication of the medium run change of the cycles components of the respective national pig (cattle) price. The synchronization of the three cycles appears to be well below the bivariate indices. This indicates that globally for the entire observation period, a movement in the same direction of all three cycles has only been observed in about one third of all months, while bivariate synchronization reached up to three quarters of all months (CP-UP).

\subsubsection{Temporal stability of synchronization}

Global synchronization however only tells one part of the story. As indicated by Figure 11, A.12 and A.13 in the appendix, synchronization appears to be temporally changing: several years of close co-movement of cycles are followed by years of loose co-movement. Therefore, we complement the evidence gained by measuring several aspects of the stability of synchronization using a rolling window version of the concordance index as outlined in Section 4.5.4 The visual comparison between the rolling window and the global estimates of the bivariate and trivariate indices is shown in Figures 11, A.12 and A.13 in the appendix. The visual inspection of the graphs depicts a rolling window movement around the global estimates, showing the dynamics of the synchronization. In the pig bivariate synchronization, all three countries have decreasing synchronization during the year 2008. On the other hand, the cattle sector presents synchronization estimates above the global estimates at the end of the period observed.

We employ the MSE-type measure (10) of the vertical distance between the rolling window concordance index to the corresponding global estimate to translate the visual impression into precise and objective measurements (Table 4). The larger the deviation between the rolling window and the global index, the more instable the synchronization between the cycles considered. The most temporally instable synchronization is between the cycles of pig and cattle price of Chile (10.5, panel VI of Figure 11) and for the cattle cycles of Chile and Uruguay (7.6, 
panel VIII of Figure 11). The lowest deviation, or least instable synchronization, is found between the cycles of pig and cattle in Brazil (1.0, panel III of Figure 11) and of cattle prices of Brazil and Uruguay (1.9, panel V of Figure 11). Thus, stability of intra-country synchronization between the movements of pig and cattle price cycles is the highest in Brazil while it is the lowest in Chile.

Table 4 Deviation between global and rolling window concordance indices

\begin{tabular}{lccccccccccc}
\hline & $\begin{array}{c}\text { CP- } \\
\text { CC }\end{array}$ & $\begin{array}{l}\text { CC- } \\
\text { UC }\end{array}$ & $\begin{array}{c}\text { CP- } \\
\text { UP }\end{array}$ & $\begin{array}{l}\text { BC- } \\
\text { CC }\end{array}$ & $\begin{array}{l}\text { BP- } \\
\text { CP }\end{array}$ & $\begin{array}{l}\text { UP- } \\
\text { UC }\end{array}$ & $\begin{array}{l}\text { BP- } \\
\text { UP }\end{array}$ & $\begin{array}{l}\text { BC- } \\
\text { UC }\end{array}$ & $\begin{array}{l}\text { BP- } \\
\text { BC }\end{array}$ & $\begin{array}{l}\text { BP- } \\
\text { UP }\end{array}$ & $\begin{array}{l}\text { BC- } \\
\text { UC }\end{array}$ \\
\hline $\begin{array}{l}\text { Devia- } \\
\text { tion }\end{array}$ & 10.5 & 7.6 & 2.8 & 2.6 & 2.3 & 2.2 & 2.1 & 1.9 & 1.0 & 2.5 & 4.9 \\
\hline
\end{tabular}

Source: Authors.

Instability of cycle synchronization between all three countries is higher for cattle (BC-CC-UC, 4.9) than for pig prices (BP-CP-UP, 2.5) as is also visible in Figures A.12 and A.13 in the appendix.

More insight into these deviations on both sides of the global estimates can be gained by assessing their symmetry in terms of the percentage of rolling window estimates above and below the global concordance index, as well as by assessing their permanence using the mean duration of phases above and below (Table 5). The share of months above and below the global estimates is calculated by dividing the number of rolling window estimates above or below the global estimate by the total number of months observed. The mean duration is calculated by dividing the sum of the durations of all continuous phases of rolling window estimates below (above) the global estimate by the number of these phases below (above).

The synchronization of pig price cycles in Chile and Uruguay, 76.9\% of all observations, exhibits the highest percentage above the global index estimate followed by the synchronization between pig prices of Brazil and Uruguay (68.6\%), Table 5. The longest (shortest) share below the global concordance index is $65.7 \%$, for the synchronization of pig and cattle prices in Uruguay (23.1\% for synchronization of pig prices between Chile and Uruguay). The trivariate rolling window concordance index for synchronization of pig price cycles between all three countries is above the global estimate for $78.7 \%$ of the observed months, while for cattle it is roughly equally above and below the respective global estimates. 
I: Brazil Pig-Chile Pig

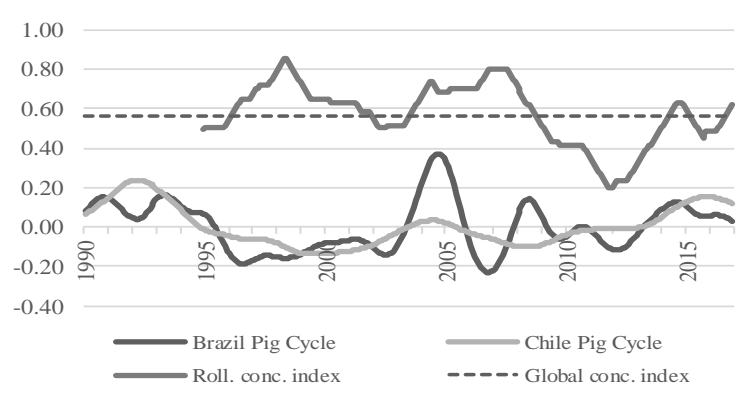

IV: Brazil Pig-Uruguay Pig

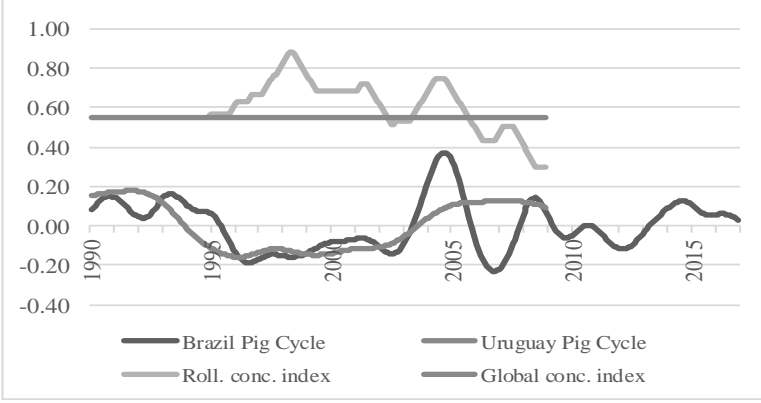

VII: Chile Pig-Uruguay Pig

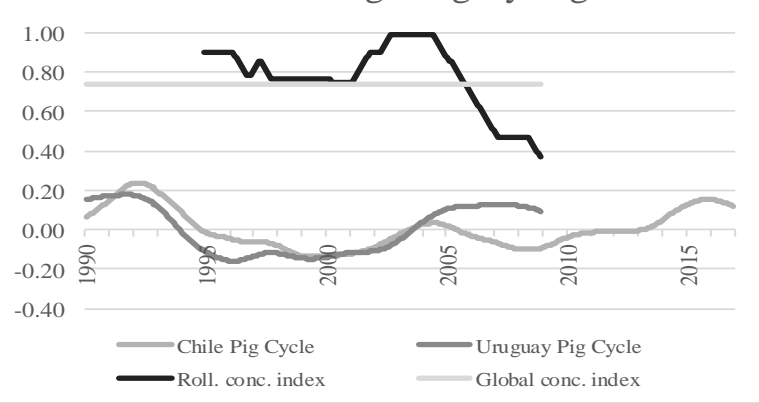

II: Brazil Cattle-Chile Cattle

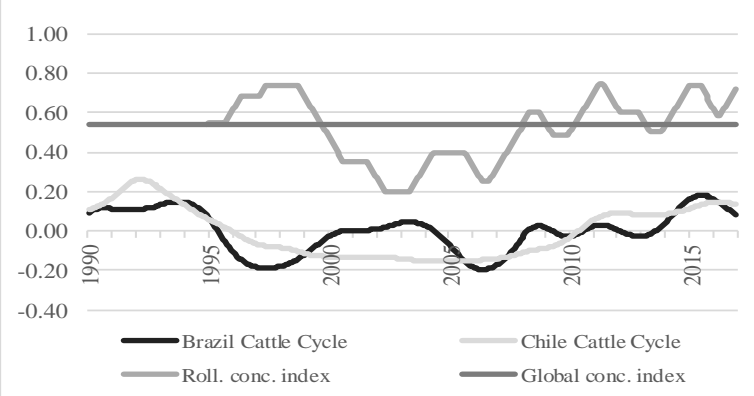

V: Brazil Cattle-Uruguay Cattle

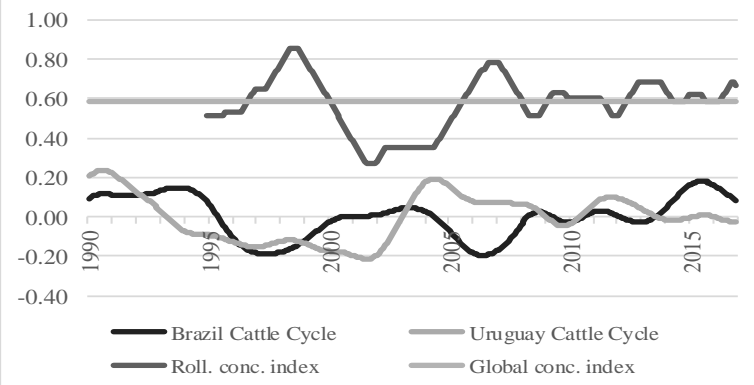

VIII: Chile Cattle-Uruguay Cattle

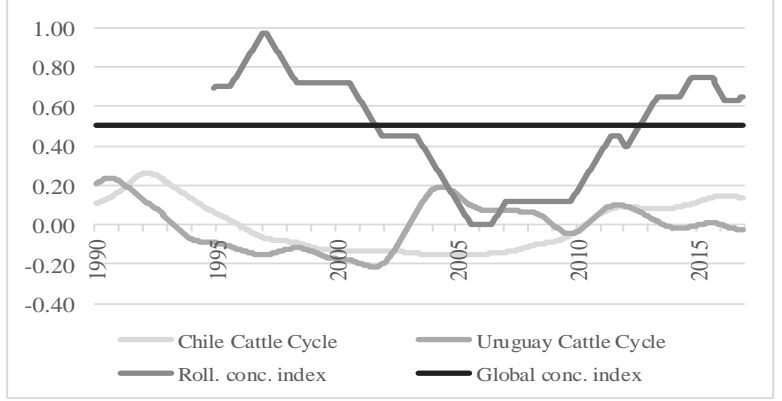

III: Brazil Pig-Brazil Cattle

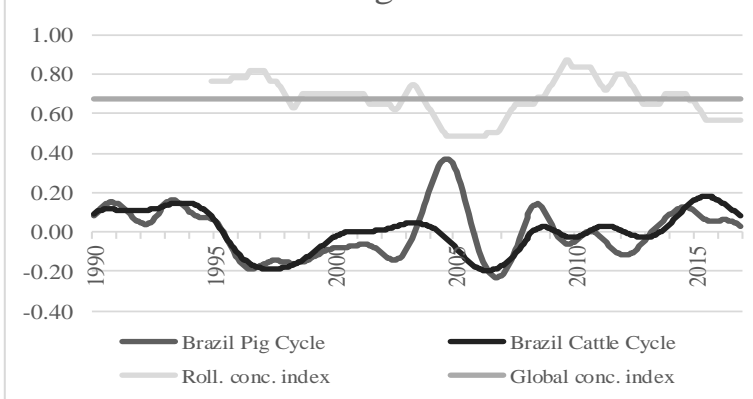

VI: Chile Pig-Chile Cattle

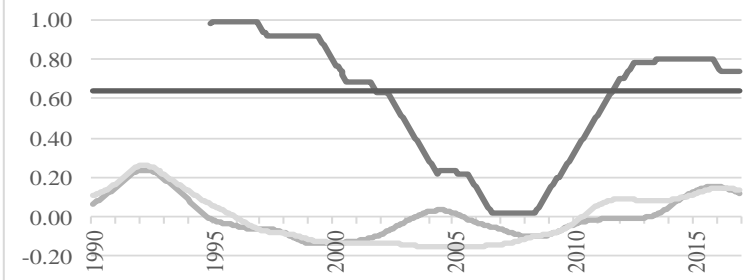

$-0.40$

Chile Pig Cycle
Roll. conc. index
Global conc. index

IX: Uruguay Pig-Uruguay Cattle

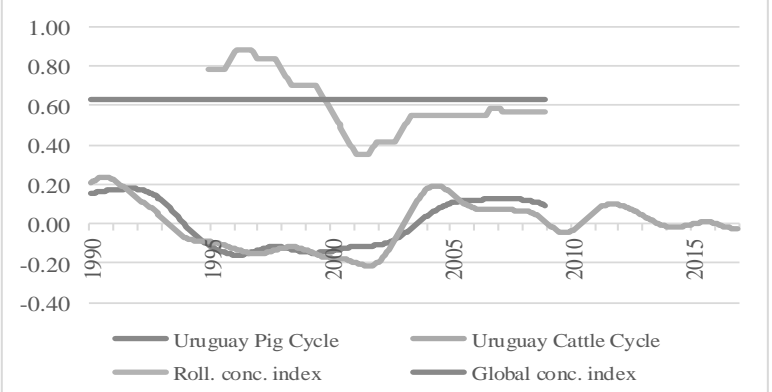

\section{Figure 11 Global vs. rolling window concordance index estimates}

Source: Authors. 
The permanence of the instability of bivariate synchronization in terms of positive deviations from the global estimate is highest for pig prices between Chile and Uruguay at 129 months. It is lowest for the pig and cattle synchronization within Brazil, with an average duration of 28 months. The most enduring negative deviations from the global estimate are found for 131 months for cattle synchronization between Chile and Uruguay, while the least enduring, for synchronization of pig and cattle price cycles, is again found within Brazil.

Table 5 Rolling window concordance index periods above and below the global concordance index

\begin{tabular}{|c|c|c|c|c|c|c|c|c|c|c|c|}
\hline & $\begin{array}{l}\text { CP- } \\
\text { UP }\end{array}$ & $\begin{array}{l}\text { BP- } \\
\text { UP }\end{array}$ & $\begin{array}{l}\text { BC- } \\
\text { UC }\end{array}$ & $\begin{array}{l}\text { BP- } \\
\text { CP }\end{array}$ & $\begin{array}{l}\text { CP- } \\
\text { CC }\end{array}$ & $\begin{array}{l}\text { BP- } \\
\text { BC }\end{array}$ & $\begin{array}{l}\text { BC- } \\
\text { CC }\end{array}$ & $\begin{array}{l}\text { CC- } \\
\text { UC }\end{array}$ & $\begin{array}{l}\text { UP- } \\
\text { UC }\end{array}$ & $\begin{array}{l}\text { BP- } \\
\text { CP- } \\
\text { UP }\end{array}$ & $\begin{array}{l}\text { BC- } \\
\text { CC- } \\
\text { UC }\end{array}$ \\
\hline $\begin{array}{l}\text { Share of } \\
\text { MSE } \\
\text { above }\end{array}$ & 76.9 & 68.6 & 59.6 & 56.6 & 55.5 & 55.1 & 52.5 & 50.2 & 34.3 & 78.7 & 50.2 \\
\hline $\begin{array}{l}\text { Share of } \\
\text { MSE be- } \\
\text { low }\end{array}$ & 23.1 & 31.4 & 40.4 & 43.4 & 44.5 & 44.9 & 47.2 & 49.8 & 65.7 & 21.3 & 49.8 \\
\hline $\begin{array}{l}\text { Mean du- } \\
\text { ration } \\
\text { above }\end{array}$ & 129 & 57 & 39 & 37 & 73 & 28 & 34 & 66 & 57 & 132 & 43 \\
\hline $\begin{array}{l}\text { Mean du- } \\
\text { ration be- } \\
\text { low }\end{array}$ & 38 & 26 & 26 & 28 & 117 & 23 & 41 & 131 & 110 & 35 & 65 \\
\hline
\end{tabular}

Source: Authors.

The stability of the trivariate synchronization of pig and cattle price cycle components differ markedly, see Table 5. Phases of synchronization which are stronger than average last 132 subsequent months for pig prices but only 43 months for cattle prices, while phases of synchronization being weaker than average take 35 months for pig, are almost as twice as long for cattle prices.

\subsubsection{Testing for synchronization stability}

As last step in the measurement of the stability of synchronization, we approximate the nonlinear rolling window estimates by the best-fitting time polynomial and test whether synchronization is stable using an F-test. We first select a model from versions $M 1, M 2, M 3$ and $M 4$ outlined in Section 4.5.4 that best fits the bivariate and trivariate rolling window concordance index curves. 'Best fit' is operationalized by the model with the lowest AIC (Akaike, 1974). Table 6 shows the best model and the p-values of the corresponding F-test 
for temporal stability for each set of cycles considered. For all models tested, we reject the null hypothesis of stable synchronization at the $5 \%$ level. ${ }^{20}$

Table 6 Selected models for stability approximation

\begin{tabular}{lcc}
\hline Country & Model & p-value \\
\hline BP-CP & M4 & $<0.01$ \\
BC-CC & M4 & $<0.01$ \\
BC-UC & M4 & $<0.01$ \\
CC-UC & M4 & $<0.01$ \\
CP-CC & M4 & $<0.01$ \\
BP-UP & M4 & $<0.01$ \\
CP-UP & M4 & $<0.01$ \\
BP-BC & M4 & $<0.01$ \\
UP-UC & M3 & $<0.01$ \\
BC-CC-UC & M3 & $<0.01$ \\
BP-CP-UP & M4 & $<0.01$ \\
\hline
\end{tabular}

Source: Authors.

\subsection{Discussion and conclusions}

Homer-Dixon et al. (2015, p. 6) emphasize that synchronization which is likely to lead to simultaneous crises "is more biophysical in origin, more intersystemic in manifestation, more global in scope, and more rapid in development". The more synchronized agricultural prices are, the greater the implied threat for food security and potential risk to producers. The higher the number of producers and consumers subject to identical price signals, the larger the aggregated demand or supply response, which may yield more destabilized prices or unfavourable food security outcomes at a larger scale.

Synchronization of economic variables is mainly examined in the context of business cycles. In agricultural economics research, the topic of synchronization has barely been addressed, although is an important aspect for the analysis of the temporal development of agricultural prices and their components. Cyclical components of price time series translate into mediumrun market signals. We concentrate on analysing this cyclical component of pig and cattle farmgate prices of Brazil, Chile and Uruguay. After we extract the cycle components using the Kalman and Hodrick-Prescott filters, we apply the concordance index developed by Harding and Pagan $(2002 ; 2006)$ for measuring bivariate and trivariate synchronization.

As the time series analysed consists of 324 observations measured over more than 25 years starting in 1990, the question of whether synchronization is stable across the entire range of

\footnotetext{
${ }^{20}$ Detailed results are provided in Table A.11 of the appendix.
} 
observations is crucial not only from a scientific point of view, but also in practical terms as long sequences of observations might be plagued with structural instabilities. The concordance index is - in the from Harding and Pagan (2002 and 2006) - a rigid index that calculates an average estimate for the entire observation period and, thus, does not allow the assessment of any dynamic developments in synchronization over time. We accomplish such measurement of the potentially temporally varying intensity of synchronization by estimating a rolling window version of this measure. This allows us to assess structural instabilities in synchronization such as symmetry and permanence by comparing synchronization estimates for the entire series with the shorter local estimates. In particular, we assess this stability using a Mean Squared Error type measure and quantify the shares of local synchronization estimates for sub-periods located above and below the global estimates.

Synchronization between pairs of pig or cattle price cycle series is in general of a moderate level, indicating that during about $60 \%$ of the observed periods the two series considered move in the same direction. The highest level of synchronization is found between the cycles of pig prices of Chile and Uruguay and the lowest between the cattle price cycles of Chile and Uruguay. Intra-country synchronization of the pig and cattle price cycles show highest synchronization levels in Brazil. Synchronization between all three cycles of each of the commodities considered is found in about one third of the observed periods.

Synchronization appears to be fairly unstable in cycles of one commodity between countries, as well as across both commodities within one country, emphasizing the importance of assessing synchronization for subsequent sub-periods of long time series. Bivariate synchronization showing the highest deviation between rolling window and global estimates, the strongest unstable synchronization, is found for pig and cattle price cycles of Chile and the cattle price cycles between Chile and Uruguay. Most stable synchronization is found between the cycles of pig and cattle in Brazil and of cattle prices between Brazil and Uruguay. Stability of intra-country synchronization of the movement of pig and cattle price cycles is highest (lowest) in Brazil (Chile).

A central implication is that governments should expand their efforts for the monitoring of agricultural and food prices. Improved monitoring efforts - as also pointed out by Baltussen et al., (2019) who indicate that many of the existing systems are insufficiently developed - would enabling ongoing synchronization monitoring. Beyond price monitoring, governments and supply chain stakeholders will profit from continuous insights into production developments, consumption trends and shocks in demand and supply. Such efforts would facilitate learning 
from past events and avoid new crises in the future. Based on these market insights, appropriate policy instruments could be developed to avoid pronounced synchronization and respond promptly to it. Future research could support this decision making by identifying and quantifying the key drives resulting in high or low synchronization as done by Baffes and Haniotis (2016), for example, for agricultural price movements in general. 


\section{Chapter 5 General Conclusions}

\subsection{Research objectives and summary of major findings}

Prices of agricultural products often vary in relatively stable recurring patterns around their long-run trends. These variations translate into fluctuations in selling prices, farm revenues, costs to consumers and result in governments in developing countries often facing liquidity constraints (Jayasuriya et al., 2012). Food price movements have had varying implications between countries, with the poorest being most affected. Current studies examining simultaneous failures in global crop production named synchronization as a threat to food security.

Monitoring agricultural price cycles creates insights into the current status of medium-run price dynamics. Therefore, we aimed to measure price cycles and their synchronization in a South American context, as it is a major worldwide meat producing region and livestock farming is connected with $85 \%$ of total Latin American agricultural land use (ECLAC et al., 2017).

This dissertation contributes to the price cycle and synchronization literature with quantitative measurement of actual price cycles characteristics (period and amplitude) and to what extent cycle components of cattle and pig prices are synchronized with each other. There is currently little in price cycle and synchronization literature over quantitative measurements of the actual degree of synchronization of food prices. In order to minimize the threat to food security there is urgent need to develop policy and economic instruments to prevent such synchronization, but this is difficult with minimal objective measurements current completed.

According to the overview of the current literature on pork and cattle price cycles, the USA is the country with the most publications on pork and cattle price cycles. 36 to 48 months is the most frequent estimate of the length of the pork price cycles in the considered publications. The cattle price cycle has frequently been found to stretch over a period of approximately 120 months. Mundlak and Huang (1996) found a cycle length of only 72 months for Argentina and Uruguay.

Chapter 2 gave an overview of the pig and cattle sectors in Brazil, Chile and Uruguay in order to better understand the dynamics of the sectors between and within the countries. It is important to highlight dependence on the international market for Chile in cattle and Uruguay in pork. Brazil consumes $80 \%$ of its production in both the pork and cattle sector, exporting the rest to 
other countries in the world. The pork sector in Brazil is marked by having integrated producers in the south and independent producers in the north, while the cattle sector is notable for extensive production in the north and center of the country and intensive production in the south. The pork sector in Chile is highly vertical integrated with few producers, in contrary the cattle sector is disorganized with poor communication through the value chain. The pork sector in Uruguay is concentrated between few producers, with competition for agricultural land against other primary producers. Uruguay has a well-organized cattle sector with reliable information flows between production and slaughter chain actors allowing for good control of the meat supply. In recent years, foreign investors have been acquiring existing slaughter capacity.

In Chapter 3, we used a transparent and reproducible structural model selection process and the Kalman filter (1960). The distinguishing feature of this dynamic model is the decomposition of a time series into a range of time-varying stochastic components. This include elements such as levels (or trends), seasonal aspects, cycles of different frequencies and irregular components. We selected optimal models and estimated the cyclic patterns of pig and cattle prices for Brazil, Chile and Uruguay.

Durations of cycles of pig and cattle prices are found to be respectively about three years and four years. These durations are in line with the literature and the biological limitations of livestock production for pig. Considering cattle, the durations found are shorter than those found in the literature. These shorter cattle cycles can be influenced by the international openness of the Chilean and Uruguayan markets. Chile is a beef importer and has to import $129 \%$ of total domestic production to satisfy domestic demand. Uruguay is a beef exporting country, approximately $70 \%$ of domestic production destined for overseas markets. The short price cycles observed in Uruguay may be due to the controlled production and efficient exchanges between the different chain actors (breeders, rearers, and fatteners) in the beef value chain, which aim to minimize discrepancies between supply and demand.

Overall, Chile has the highest and Brazil the smallest relative cycle amplitudes for pork and cattle prices. This knowledge can inform producers through forecasts on price developments in the short run. It is useful for guiding policy makers on the timing of policy interventions for influencing the duration or the amplitudes of cycles.

In Chapter 4, we measured to what extent the cycle components of cattle and pig prices of Brazil, Chile and Uruguay are synchronized with each other. We apply the Kalman (Kalman, 1960) and Hodrick-Prescott filter (Hodrick and Prescott, 1997) to extract the cycle components 
from the price series. We measure synchronization in a bivariate and trivariate form using the concordance index developed by Harding and Pagan (2002; 2006). This approach has not yet been used to analyze synchronization of agriculture price cycles to the best of our knowledge. This measure is calculated as an average characteristic of two or more time series. We add to that the measurement using a rolling window version in order to be able to evaluate how synchronization developed through subsequent subperiods of years of duration.

The literature reviewed in Chapter 4 reveals a lack of synchronization measurement in agriculture cycles, with synchronization most frequently analyzed in the contexts of business cycle, stock market and housing price cycle synchronization. The majority of these papers confirm synchronization in approximately ninety percent of the studies. The papers reviewed use various approaches to quantify synchronization, the main methodology used for cycle synchronization measurement is the correlation index, followed by the concordance index and structural time series analysis.

The simultaneous spike in agriculture prices at the global scale in 2007/2008 has substantially increased the interest in such synchronization of prices and awareness of the consequences. Nevertheless, economic literature has devoted scant attention to the measurement of synchronization in prices. We fill this gap by measuring the synchronization between the medium-term cycle components of pig and cattle prices in three South American countries since 1990. For this we use the concordance index with rolling window estimates to assess the potentially temporally varying stability of synchronization as well as its symmetry and permanence. Synchronization between pairs of pig and cattle price cycle series is in general of a moderate level. Cycles of bi- and trivariate prices are found to move into the same direction during about two thirds and one third of the observed periods respectively. Synchronization appears to be fairly instable between the cycles in prices of one commodity between countries as well as across commodities within one country. This emphasizes the importance of allowing for temporally varying synchronization in the context of long time series. In most cases, the instabilities in synchronization are asymmetric and show starkly differing permanence, depending on their direction of deviation. These results imply the governments should expand their efforts and institutional base for monitoring agricultural and food prices.

\subsection{Policy and Managerial Implications}

Price fluctuations influence food security, as it is often related to income and availability of food. High food prices lower purchasing power, thus leading to food insecurity in vulnerable households against rising demand for animal protein (ECLAC et al., 2017; and Barrero et al., 
2017). An efficient food security policy should focus on the poor and not just on available supplies on the markets (Koester and El-Agraa, 2011). But not only supply and price fluctuations affect food security, synchronization is also a threat for food security. HomerDixon et al. (2015) emphasize the necessity to develop appropriately policy instruments to avoid synchronization and react quickly to shocks.

In this sense, there is a necessity to improve monitoring of agricultural and food prices, develop policy instruments and programs to avoid synchronization and shocks. In order to quickly react to shocks and avoid supply disruptions we recommend the development of emergency programs. For example, in the case of animal diseases, the development of animal health programs for rapid isolation of infections and disease eradication will help ensure phytosanitary standards. For natural catastrophes such as droughts, flooding, fires or volcanic eruptions, quick provisions of water supply and rapid forage supplement and/or an evacuation of livestock from the sector. The implementation of catastrophic insurance subsidies to avoid financial problems, together with the development of cheap credits for the reconstruction of infrastructure, herd or grassland recovery would also be advisable. On the demand side, it is important to rapidly communicate sanitary and supply problems and clarify consequences. Quick reactions to problems increase trust and reciprocity in long-term relationships.

In order to fill the increasing demand for meat, it is necessary both to increase production in volume and efficiency. It is advisable to support farmers in adopting technology transfers through field days, technology tours, by the improvement of production systems, livestock feeding support, grassland improvement, water management strategies, health and vaccines support, genetic improvements, introduction of regionally suitable breeds and support for insemination, and financial support or credit at a time of expanding production.

With changing demand and more awareness about the environment and animal welfare, it is important to highlight the importance of programs to enhance the communication and integration of the entire pork and beef value chains. Therefore, support must be given to the creation of entities that increase communication and integration as a way of producing market driven improvements, improving coordination and reaction to changes in demand. In order to better monitor meat standards and increase awareness around meat of different qualities at different prices, it is recommended to improve traceability and classification of meat. This involves added value to production in terms of consumer information concerning aspects such as: breed, age, feed, use of antibiotics and hormones, animal health, freshness and duration of processing. 
It is important to extend the concept to clean production to the livestock and meat sector. Clean production is a preventive business management strategy applied to products, processes and organizations, whose objective is to minimize emissions and/or discharges at the source, reducing risks to human and environmental health, and simultaneously increasing competitiveness. Governments must consider acceptance of productive processes at a societal level to avoid strikes and plant closures due to intensification or production on a larger scale with high levels of pollution and negative spillover effects for surrounding communities.

Policies should be developed that give small farmers the opportunity to participate in the production of meat for export based on quality standards, and avoid a monopoly on the production and export of meat products by large companies. An exit from supply chains of small farmers must be avoided by making them more competitive through such actions as linking them with cooperatives.

Additionally, to improve rural life infrastructure must be improved in rural areas. This makes them more attractive to avoid migration from the countryside, and upgraded roads facilitates accesses to production and export hubs. Increasing family farming productivity will also aid in improving food security.

Governments should support expansion to new markets and take advantage of niches, adding extra value to meat products. As is the case in Uruguay, which exports live standing calves to Turkey, or the production of kosher meat. In the future, production should focus on animal welfare, developing certifications and production processes that meet new market requirements. The OECD and FAO (2019) note increasing attention of consumers to animal welfare and how meat is produced.

An liberalized market economy would help mitigate fluctuations in regional production (Koester and El-Agraa, 2011; FAO et al., 2011). In this sense, it is important to develop policies to expand external markets and improve internal markets. For external markets, an aspect that is fundamental is the streamlining of sanitary agreements and homologation tasks within frameworks of both new and existing free trade agreements. Developing trade programs will support both domestic and international trade, encourage production risk insurance, ensure stocks of domestic commodities, and help develop financial instruments to support producers in periods of crisis or expansion. Governments must also develop trade agreements to reduce entry barriers to other countries.

High dependency on international prices due to the high export percentages of domestic production implies risk. Maintaining stable business relationships with internal markets through 
public organizations and producer associations may be invaluable for companies in the domestic market.

Last but not least, we recommend the monitoring of prices, synchronization and production cycles, and trends and shocks, in order to learn from past events and avoid new crisis to ensure food security. Uruguay has monitoring programs for cattle production, INAC has records of crosses (pairing), births, production and trade in livestock in the three developmental stages at the domestic level.

\subsection{Limitations and recommendations for further research}

This dissertation has some limitations which should be mentioned in order to serve as a guide for further studies.

The dissertation is based on the analysis of three countries in pig and cattle price time series. In the case of Uruguay, it was very difficult to access pig time series after 2008, and therefore the price cycles and their synchronization were only calculated to 2008. Another limitation of the study is the exclusion of Argentina, one of the main beef producers in South America. It was not possible to find price series of cattle at farm or fairs over a long period of time, only data from 2006 was located, which would not have facilitated the calculation of price cycles. As for the pig price data, this information was not available at the commencement of this dissertation.

Quantities of meat produced could also be included, not only price data as we did. It is also recommended to analyze the actual availability of meat or livestock, including production, imports and exports, in order to ascertain domestic meat availability. This is important considering that Uruguay exports $70 \%$ of its beef production and imports $60 \%$ of pork consumed, and Chile imports beef volumes totaling $129 \%$ of domestic production. In future studies focused on the synchronization of cycles, the analysis of the influence of shocks such as weather, oil crisis, and diseases is recommended. This could also include how implementation of trade barriers, trade agreements, and financial liberalization influence cycles. In order to measure the international synchronization of price cycles we recommend analyzing international prices of beef and pork and comparison to domestic prices. This cycle synchronization analysis can be also be performed on cycles at the international or South American price level, with a model based on multivariate analysis that builds a cycle from all price series included in the model, and from there calculates the deviation of each domestic cycle with respect to the cycle calculated based on all time series. 
Given that the main composition of the Chilean cattle herd is either dual-purpose or dairybreeds, there is a close relationship between these two sectors (meat and milk). In that sense, there are dairy producers who are dedicated to the raising and fattening of their calves, whether they are dairy or meat breed crosses. Additionally, in situations where dairy rotations occur in the dairy industry, some calves are removed from production and marketed for fattening (either directly or through fairs). It would also be of interest to analyze synchronization of the meat and milk cycles due to dual purpose breeds.

The analysis of agricultural price cycles and synchronization, as presented here, sheds light on crucial aspects of price dynamics. By understanding and identifying such dynamics, governments and supply chain stakeholders will profit from continuous insights into production developments, consumption trends and shocks in demand and supply. Such efforts would facilitate learning from past events and avoid new crises in the future. Based on these market insights, appropriate policy instruments can be developed to avoid pronounced synchronization and respond promptly, thereby mitigating food insecurity. 


\section{Bibliography}

Aadland, D. (2004). Cattle cycles, heterogeneous expectations and the age distribution of capital. Journal of Economic Dynamics and Control, 28(10), 1977-2002. https://doi.org/10.1016/j.jedc.2003.08.003

Abbott, P. C. (2009). Development dimensions of high food prices. OECD Food, Agriculture and Fisheries Papers, 18(18), 1-96. https://doi.org/10.1787/222521043712

Acuña, D., and Pizarro, M. J. (2019). La industria porcina en Chile: oportunidades y desafíos para su sustentabilidad Abril de 2019. Santiago, Chile. https://www.odepa.gob.cl/wpcontent/uploads/2019/04/articulo-industria_porcina.pdf

Afef, M. T. (2014). Financial Liberalization and Stock Market Behaviour in Emerging Countries. Journal of Behavioural Economics, Finance, Entrepreneurship, Accounting and Transport, 2(1), 8-17. https://doi.org/10.12691/jbe-2-1-2

Aiolfi, M., Catão, L. A. V., and Timmermann, A. (2011). Common factors in Latin America's business cycles. Journal of Development Economics, 95(2), 212-228. https://doi.org/10.1016/j.jdeveco.2010.04.003

Akaike, H. (1974). A new look at the statistical model identification. IEEE Transactions on Automatic Control, 19(6), 716-723. https://doi.org/10.1109/TAC.1974.1100705

Akimov, A., Stevenson, S., and Young, J. (2015). Synchronisation and commonalities in metropolitan housing market cycles. Urban Studies, 52(9), 1665-1682. https://doi.org/10.1177/0042098014535643

Alvarez, M. (2014). Atlas de la carne. Hechos y cifras sobre los animales que comemos. Santiago, Chile. https://www.boell.de/en/meat-atlas

Anderson, D. P., Robb, J. G., and Mintert, J. (1996). The Cattle Cycle. Managing for Today's Cattle Market and Beyond, 4. https://ag.arizona.edu/arec/wemc/cattlemarket/CatlCycl.pdf. Accessed 14 October 2015

Anderson, W. B., Seager, R., Baethgen, W., Cane, M., and You, L. (2019). Synchronous crop failures and climate-forced production variability. Science Advances, 5(7), 9. https://doi.org/10.1126/sciadv.aaw1976

Arkolakis, C., and Ramanarayanan, A. (2009). Vertical specialization and international business cycle synchronization. Scandinavian Journal of Economics, 111(4), 655-680. https://doi.org/10.1111/j.1467-9442.2009.01580.x

Artis, M. J., and Zhang, W. (1997). International Business Cycles and the ERM: Is There a European Business Cycle? International Journal of Finance \& Economics, 2(1), 1-16. https://doi.org/10.1002/(SICI)1099-1158(199701)2:1<1::AID-IJFE31>3.0.CO;2-7

ASPROCER. (2019). Asociados en Asprocer. http://www.asprocer.cl/asociacion/asociados/. Accessed 8 September 2019

Baffes, J., and Haniotis, T. (2016). What Explains Agricultural Price Movements? Journal of Agricultural Economics, 67(3), 706-721. https://doi.org/10.1111/1477-9552.12172

Baltussen, W., Drabik, D., Dries, L., Galen van, M., Gardebroek, C., Ihle, R., ... Oosterkamp, 
E. (2019). Monitoring of Prices and Margins in EU Food Supply Chains: Existing and Alternative Approaches. Luxembourg: Publications Office of the European Union. https://doi.org/10.2760/197814

Barker, J., Sedik, D., and Nagy, J. G. (2009). Food Price Fluctuations, Policies and Rural Development in Europe and Central Asia. In FAO-UNDP Europe and Central Asia Regional Consultation (p. 98). 5-6 December 2008, Budapest Hungary: FAO. http://www.fao.org/3/i1059e/i1059e00.pdf

Barrero, D., Williams, G. W., and Anderson, D. (2017). The Outlook for Agriculture and Rural Development in the Americas: A Perspective on Latin America and the Caribbean 2017 -2018. Reports. San Jose, Costa Rica. http://www.fao.org/3/i8048en/I8048EN.pdf

Baxter, M., and King, R. G. (1999). Measuring: Business cycles: Approximate Band-pass filters for Economic Time Series. The Review of Economics and Statistics, 81(4), 575593. https://doi.org/10.1111/1468-2354.t01-1-00076

Bell, W., Carballo, C., Castro, G., and Barlocco, N. (2014). Situación y perspectivas de la producción porcina en Uruguay. In Jornadas Nacionales de Actualización Porcina y VI Encuentro del CIAP (p. 7). Montevideo, Uruguay.

Berg, E., and Huffaker, R. (2015). Economic Dynamics of the German Hog-Price Cycle. Int. J. Food System Dynamics, 6(2), 64-80. https://doi.org/10.18461/ijfsd.v6i2.621

Bifaretti, A., Brusca, E., and Jairala, M. (2014). Cambios socioeconómicos y demanda de carnes : ¿Cómo se construye el mapa del consumo de proteínas cárnicas en el mercado argentino? (No. 21- 23 october 2014). XLV Reunión Anual de la AAEA y IV Congreso Regional de Economía Agraria. Buenos Aires: Instituto de Promoción de la Carne Vacuna Argentina IPCVA. http://www.ipcva.com.ar/files/AAEA2014web.pdf

Bowman, K. O., and Shenton, L. R. (1975). Omnibus test contours for departures from normality based on $\sqrt{\mathrm{b} 1} 1$ and b2. Biometrika, 62(2), 243-250. http://dx.doi.org/10.1093/biomet/62.2.243

Burns, A. F., and Mitchell, W. C. (1946). Measuring Business Cycles (National B.). New York, USA: National Bureau of Economic Research, Inc. https://www.nber.org/books/burn46-1

Calderón, C. (2007). Trade, Specialization and Cycle Synchronization: Explaining Output Comovement between Latin America, China and India (No. 66621). World Bank, LCRCE. http://citeseerx.ist.psu.edu/viewdoc/download?doi=10.1.1.530.4486\&rep=rep1\&type=pd $\mathrm{f}$

Calderón, C., Chong, A., and Stein, E. (2007). Trade intensity and business cycle synchronization: Are developing countries any different? Journal of International Economics, 71(1), 2-21. https://doi.org/10.1016/j.jinteco.2006.06.001

Camacho, M., and Perez-Quiros, G. (2006). A New Framework to Analyze Business Cycle Synchronization. In Elsevier (Ed.), Nonlinear Time Series Analysis of Business Cycles (Nonlinear., pp. 133-149). Amsterdam: Emerald Group Publishing Limited. https://doi.org/10.1016/S0573-8555(05)76005-3

Camacho, M., Perez-Quiros, G., and Saiz, L. (2006). Are European business cycles close enough to be just one? Journal of Economic Dynamics and Control, 30(9-10), 16871706. https://doi.org/10.1016/j.jedc.2005.08.012 
Candelon, B., Piplack, J., and Straetmans, S. (2008). On measuring synchronization of bulls and bears: The case of East Asia. Journal of Banking and Finance, 32(6), 1022-1035. https://doi.org/10.1016/j.jbankfin.2007.08.003

Carvalho, V. M., and Harvey, A. C. (2005). Convergence in the trends and cycles of eurozone income. Journal of Applied Econometrics, 20(2), 275-289. https://doi.org/10.1002/jae.820

Cerqueira, P. a., and Martins, R. (2009). Measuring the determinants of business cycle synchronization using a panel approach. Economics Letters, 102(2), 106-108. https://doi.org/10.1016/j.econlet.2008.11.016

Coase, R., and Fowler, R. (1935). Bacon production and the pig-cycle in Great Britain. Economica, 2(6), 142-167. https://doi.org/Doi 10.2307/2548676

Darvas, Z., and Szapáry, G. (2008). Business cycle synchronization in the enlarged EU. Open Economies Review, 19(1), 1-19. https://doi.org/10.1007/s11079-007-9027-7

Delajara, M. (2012). Sincronizacion entre los Ciclos Economicos de Mexico y Estados Unidos. Nuevos Resultados con Base en el Analisis de los Indices Coincidentes Regionales de Mexico (No. 2012- 01). http://www.banxico.org.mx/publicaciones-yprensa/documentos-de-investigacion-del-banco-de-mexico/\%7BD474B564-2F8D-23076D7C-771D255A86DA\%7D.pdf

Duarte, A., and Holden, K. (2003). The business cycle in the G-7 economies. International Journal of Forecasting, 19(4), 685-700. https://doi.org/10.1016/S0169-2070(02)00074-2

Duran, H. E. (2011). Short-Run Dynamics of Income Disparities and Regional Cycle Synchronization (No. 09/WP/2011). SSRN Electronic Journal. University of Venice, Venice. Retrieved from http://www.ssrn.com/abstract=1904884

Durbin, J., and Watson, G. S. (1950). Testing for Serial Correlation in Least Squares Regression: I. Biometrika, 37(3-4), 409-428. https://doi.org/10.1093/biomet/37.3-4.409

ECLAC, FAO, and IICA. (2017). The Outlook for Agriculture and Rural Development in the Americas: A Perspective on Latin America and the Caribbean 2017-2018. San Jose, Costa Rica. http://www.fao.org/3/i8048en/I8048EN.pdf

Eickmeier, S., and Breitung, J. (2006). How synchronized are new EU member states with the euro area? Evidence from a structural factor model. Journal of Comparative Economics, 34(3), 538-563. https://doi.org/10.1016/j.jce.2006.06.003

Ezekiel, M. (1938). The Cobweb Theorem. The Quarterly Journal of Economics, 52(2), 255280. http://www.jstor.org/stable/1881734

FAO. (2010). Price Volatility in Agricultural Markets. Evidence, impact on food security and policy responses. FAO Policy Brief. Rom. https://doi.org/10.1007/978-1-4419-7634-5_2

FAO. (2011). World Livestock 2011- Livestock in food security. Rome: FAO. http://www.fao.org/3/i2373e/i2373e00.htm

FAO. (2013). World Livestock 2013 - Changing disease landscapes. World Livestock 2013: changing disease landscapes. Rome: FAO. http://www.fao.org/3/i3440e/i3440e.pdf

FAO. (2019). Livestock Primary. http://www.fao.org/faostat/en/\#data/QL. Accessed 12 September 2019

FAO, WFP, and IFAD. (2011). The State of Food Insecurity in the World: How does international price volatility affect domestic economies and food security? Rome. 
http://www.fao.org/3/a-i2330e.pdf

Farías, C., Espinoza, Á., and Giacomozzi, J. (2016). Transmisión de precios en la cadena de la carne bovina en Chile. Santiago, Chile. https://www.odepa.gob.cl/wpcontent/uploads/2017/12/cadenaCarneBovina.pdf

Farina, J., and Rodriguez, J. (2013). Acceso a la alimentación : el consumo de carne vacuna en Argentina. Ciclos en la historia, la economía y la sociedad, 21(42), 1851-3735. http://www.scielo.org.ar/scielo.php?script=sci_arttext\&pid=S1851$37352013000200003 \& \operatorname{lng}=$ es\&tlng=es

Fava, M., de Lima, J. C., Chaves, N., Junqueira, M., Bordonal, R., Gerbasi, T., ... Vriesekoop, F. (2016). Mapeamento da suinocultura brasileira. Observatorio de la Economía Latinoamericana. Brasilia, Brazil. http://www.abcs.org.br/attachments/01_Mapeamento_COMPLETO_bloq.pdf

Fengying, N., Ling, D., and Jieying, B. (2009). Fluctuation and Cycle of Pork Price in China. In International Association of Agricultural Economists Conference (p. 15). http://ageconsearch.umn.edu/record/51654

Fiess, N. (2007). Business cycle synchronization and regional integration: A case study for Central America. The World Bank Economic Review, 21(1), 49-72. https://doi.org/10.1093/wber/lhl014

Fisher, T. C. ., and Konieczny, J. D. (2000). Synchronization of price changes by multiproduct firms: evidence from Canadian newspaper prices. Economics Letters, 68(3), 271-277. https://doi.org/10.1016/S0165-1765(00)00231-7

Frankel, J. A., and Rose, A. K. (1998). The Endogeneity of the Optimum Currency Area Criteria. Economic Journal, 108(449), 1009-1025. https://www.nber.org/papers/w5700.pdf

Franzmann, J. R. (1971). Cattle Cycles Revisited. Southern Journal of Agricultural Economics, 3(01), 69-76. https://doi.org/10.1017/S0081305200010153

Gaechter, M., Riedl, A., and Ritzberger-Gruenwald. (2012). Business Cycle Synchronization in the Euro Area and the Impact of the Financial Crisis. Monetary Policy \& the Economy. https://www.oenb.at/dam/jcr:094e45fe-86e4-40b7-a14eb550bcf177c5/mop_2012_q2_analyse02_tcm16-249562.pdf

Geise, A., and Pilatowska, M. (2013). Synchronization of Crude Oil Prices Cycle and Business Cycle for the Central Eastern, 13(1482), 87-100. https://doi.org/10.12775/DE M.2013.010

Gonçalves, C. E. S., Rodrigues, M., and Soares, T. (2009). Correlation of business cycles in the euro zone. Economics Letters, 102(1), 56-58. https://doi.org/10.1016/j.econlet.2008.11.011

Goodwin, J. W. (1994). Agricultural Price Analysis and Forecasting (1st Editio.). New York, USA: Wiley.

Gorga, L. (2018). Cadena de cerdo: situación y perspectivas. ANUARIO 2018 OPYPA. Montevideo, Uruguay. https://descargas.mgap.gub.uy/OPYPA/Anuarios/Anuario 2018/ANUARIO OPYPA 2018 WEB con vínculo.pdf

Hanau, A. (1928). Die Prognose der Schweinepreise. Viertelsjahrhefte zur Konjunkturforschung, Sonderheft 7, Institut für Konjunkturforschung, Berlin. 
Harding, D., and Pagan, A. (2002). Dissecting the cycle: a methodological investigation. Journal of Monetary Economics, 49(2), 365-381. https://doi.org/10.1016/S03043932(01)00108-8

Harding, D., and Pagan, A. (2006). Synchronization of cycles. Journal of Econometrics, 132(1), 59-79. https://doi.org/10.1016/j.jeconom.2005.01.023

Harlow, A. A. (1960). The Hog Cycle and the Cobweb Theorem. American Journal of Agricultural Economics, 42(4), 842-853. https://doi.org/10.2307/1235116

Hennicke, L., and Lopez, J. (2006). Chile. Livestock and Products. Pork Annual 2006 (No. CI6024). Santiago, Chile. https://apps.fas.usda.gov/gainfiles/200608/146208792.pdf

Hennicke, L., and Sloop, C. M. (2005). Chile. Livestock and Products. Pork Annual 2005 (No. CI5016). Santiago, Chile. https://apps.fas.usda.gov/gainfiles/200509/146130753.pdf

Hirata, H., Kose, M. A., Otrok, C., and Terrones, M. E. (2012). Global House Price Fluctuations: Synchronization and Determinants. NBER International Seminar on Macroeconomics, 9(1), 119-166. https://doi.org/10.1086/669585

Hodrick, R. J., and Prescott, E. C. (1997). Postwar U . S . Business Cycles : An Empirical Investigation. Journal of Money, Credit and Banking, 29(1), 1-16. http://www.jstor.org/stable/2953682

Holst, C., and von Cramon-Taubadel, S. (2012). International Synchronisation of the Pork Cycle. Acta Oeconomica et Informatica, 15(1), 18-23. http://ageconsearch.umn.edu/record/133229

Holt, M. T., and Craig, L. A. (2006). Nonlinear Dynamics and Structural Change in the U.S. Hog--Corn Cycle: A Time-Varying STAR Approach. American Journal of Agricultural Economics, 88(1), 215-233. https://doi.org/10.1111/j.1467-8276.2006.00849.x

Homer-Dixon, T., Walker, B., Biggs, R., Crépin, A. S., Folke, C., Lambin, E. F., ... Troell, M. (2015). Synchronous failure: The emerging causal architecture of global crisis. Ecology and Society, 20(3). https://doi.org/10.5751/ES-07681-200306

Huang, X., An, H., Fang, W., Gao, X., Wang, L., and Sun, X. (2016). Impact assessment of international anti-dumping events on synchronization and comovement of the Chinese photovoltaic stocks. Renewable and Sustainable Energy Reviews, 59, 459-469. https://doi.org/10.1016/J.RSER.2015.12.231

Imbs, J. (1998). Co-Fluctuations. Cahiers de Recherches Economiques du Département d'Econométrie et d'Economie politique (DEEP), 9819, Université de Lausanne, Faculté des HEC, DEEP. http://www.unil.ch/de/files/live/sites/de/files/working-papers/9819.pdf

Imbs, J. (2004). Trade , Finance, Specialization , and Synchronization. The Review of Economics and Statistics, 86(3), 723-734. http://www.mitpressjournals.org/doi/pdf/10.1162/0034653041811707

Imbs, J. (2006). The real effects of financial integration. Journal of International Economics, 68(2), 296-324. https://www.sciencedirect.com/science/article/pii/S002219960500053X

INAC. (2017). Series Históricas. Base de Datos. http://www.mgap.gub.uy/serieshistoricas/hshistoricas.aspx. Accessed 6 February 2017

INE. (2017). Índice de Precios del Comnsumidor. Índice de Precios del Comnsumidor. http://www.ine.gub.uy/ipc-indice-de-precios-al-consumo. Accessed 6 February 2017

Inklaar, R., Jong-A-Pin, R., and de Haan, J. (2008). Trade and business cycle synchronization 
in OECD countries-A re-examination. European Economic Review, 52(4), 646-666. https://doi.org/10.1016/j.euroecorev.2007.05.003

IPEA. (2017). Institute for Applied Economic Research. IPEADATA. http://www.ipeadata.gov.br/Default.aspx. Accessed 6 February 2017

Jansen, J., and Stokman, A. C. J. (2014). International business cycle co-movement: the role of FDI. Applied Economics, 46(4), 383-393. https://doi.org/10.1080/00036846.2013.844327

Jaulin-Mendez, O., Bustos-Peláez, J. C., Ojeda-Joya, J. N., and Bustos-Pel, J. C. (2015). The Interdependence between Commodity-Price and GDP Cycles : A Frequency Domain Approach (No. 913). Bogota. http://www.banrep.gov.co/en/borrador-913

Jayasuriya, S., Mudbhary, P., and Broca, S. S. (2012). Food price spikes, increasing volatility and global economic shocks: coping with challenges to food security in Asia. Food and Agriculture Organization of the United Nations. Bangkok. http://www.fao.org/docrep/016/i3031e/i3031e00.htm

Jelavich, M. S. (1973). Distributed Lag Estimation of Harmonic Motion in the Hog Market. American Journal of Agricultural Economics, 55(2), 223-224. https://doi.org/10.2307/1238442

Joseph, K., and Meador, M. M. (2018). Uruguay. Livestock and Products Annual. Uruguayan Livestock Report 2018.

https://apps.fas.usda.gov/newgainapi/api/Report/DownloadReportByFileName?fileName =Livestock and Products Annual_Buenos Aires_Uruguay_9-21-2018

Kalman, R. E. (1960). A New Approach to Linear Filtering and Prediction Problems. ASME. J. Basic Eng., 82(1), 35-45. https://doi.org/10.1115/1.3662552

Köbrich, C., Bravo-Peña, F., Rivas, T., Maino, M., Agüero, D., Barcellos, J., ... Paniagua, P. (2018). Estudio para la caracterización de la faena de animales y de los canales de comercialización de la carne bovina en los países del MERCOSUR. Santiago, CHILE. https://www.odepa.gob.cl/wp-content/uploads/2018/12/estudioCarneMercosur2018.pdf

Koester, U. (2010). Grundzüge der landwirtschaftlichen Marktlehre (4.). München: Franz Vahlen.

Koester, U., and El-Agraa, A. (2011). The Common Agricultural Policy. In The European Union, Economics and Policies (Ninth Edit., pp. 373-411). Cambridge University Press. https://www.researchgate.net/publication/259526974_The_Common_Agricultural_Polic y_in_El-

Agraa_A_M_Hrsg_The_European_Union_Economics_and_Policies_9th_ed_Cambridge _University_Press_306-334

Kohls, R. L., and Uhl, J. N. (1990). Marketing of Agricultural Products (7th ed.). New York, USA: Macmillan Publishing Company.

Krugman, P. (2008, April 7). Grains Gone Wild. The New York Times, p. A21. New York, USA. http://www.nytimes.com/2008/04/07/opinion/07krugman.html?_r=1\&oref=slogin

Kulshreshtha, S. N., and Wilson, A. G. (1973). A Harmonic Analysis of Cattle and Hog Cycles in Canada. Canadian Journal of Agricultural Economics/Revue canadienne d'agroeconomie, 21(3), 34-45. https://doi.org/10.1111/j.1744-7976.1973.tb01034.x

Labys, W. C., Achouch, A., and Terraza, M. (1999). Metal prices and the business cycle. Resources Policy, 25(4), 229-238. https://doi.org/10.1016/S0301-4207(99)00030-6 
Leiva-Leon, D. (2014). A New Approach to Infer Changes in the Synchronization of Business Cycle Phases (No. 2014-38). Bank of Canada Working Paper. Ottawa, Ontario. https://doi.org/10.2139/ssrn.2691659

Li, L. (2017). Business Cycle Synchronization, Value Added Trade, Equity Market Linkages and Industrial Structure. In American Economic Association (AEA) 2017 Annual Conference (p. 14). Chicago, USA.

https://www.aeaweb.org/conference/2017/preliminary/paper/5DAbsSYG

Lima, A. (2015). Agricultura: O Agronegócio da Suinocultura Brasileira. Análise de conjuntura. Informaçôes fipenformaçôes fipe, 3-5. https://www.fipe.org.br/Content/downloads/publicacoes/bif/2015/3-5-agr.pdf

Ljung, G. M., and Box, G. E. P. (1978). On a measure of lack of fit in time series models. Biometrika, 65(2), 297-303. http://dx.doi.org/10.1093/biomet/65.2.297

Ludtke, C. (2010). Os caminhos da suinocultura. Avicultura Industrial. http://file.aviculturaindustrial.com.br/Material/Tecnico/caminhos_suinocultura.pdf

MAGYP. (2014). Canales de comercialización de hacienda bovina: "El rol de los mercados electrónicos en Australia, Brasil, Estados Unidos y Uruguay.” Buenos Aires, Argentina. https://www.agroindustria.gob.ar/sitio/areas/bovinos/informacion_interes/informes_histo ricos/_archivos//000013_Sistemas de comercializacion electrónica/000005-Sistemas de comercializacion electrónico de hacienda bovina - AU BR USA UY.pdf

Mehrabi, Z., and Ramankutty, N. (2019). Synchronized failure of global crop production. Nature Ecology \& Evolution, 3(5), 780-786. https://doi.org/10.1038/s41559-019-0862-X

Michaelides, P. G., and Papageorgiou, T. (2012). On the transmission of economic fluctuations from the USA to EU-15 (1960-2011). Journal of Economics and Business, 64(6), 427-438. https://doi.org/10.1016/j.jeconbus.2012.08.003

Mise, E., Kim, T.-H., and Newbold, P. (2005). On suboptimality of the Hodrick-Prescott filter at time series endpoints. Journal of Macroeconomics, 27(1), 53-67. https://doi.org/10.1016/j.jmacro.2003.09.003

Mundlak, Y., and Huang, H. (1996). International comparisons of cattle cycles. American Journal of Agricultural Economics, 78(4), 855-868. https://doi.org/https://doi.org/10.2307/1243843

Murphy, J. J. (1999). Technical Analysis of the Financial Market. (N. Y. I. of Finance, Ed.) (First edit.). New York, USA: Penguin Group. https://www.academia.edu/keypass/QVVFTGNITndDTGVMMkhlTlllNm0zTENBazgw SzZmMEVid3JqQVBRS3d0cz0tLU0rVjN2dGh5SGdJL09KY3dyNjI4Mnc9PQ==-aea6a5ba79bf658a8c458d4cb5716fcabf7607a7/t/mfjos-NszzC4zrR2kP/attachments/31603538/download_file

Muth, J. F. (1961). Rational Expectations and the Theory of Price Movements. Econometrica, 29(3), 315-335. https://doi.org/10.2307/1909635

Nerlove, M. (1958). Adaptive Expectations and Cobweb Phenomena. The Quarterly Journal of Economics, 72(2), 227-240. https://doi.org/10.2307/1880597

ODEPA. (2005). Agricultura Chilena 2014 una perspectiva a mediano plazo. Santiago de Chile. https://www.odepa.gob.cl/odepaweb/serviciosinformacion/publica/Agricultura2014.pdf

ODEPA. (2007). Caracterizacion de la Demanda de Carne Bovina y Evaluacion de Bienes 
Sustitutos. Santiago, Chile.

http://www.odepa.gob.cl/publicaciones/estudios/caracterizacion-de-la-demanda-decarne-bovina-y-evaluacion-de-bienes-sustitutos

ODEPA. (2017). Bureau for research and agriculture policy.

http://www.odepa.cl/precios/series-de-tiempo/. Accessed 6 February 2017

OECD, and FAO. (2018). OECD-FAO Agricultural Outlook 2018. OECD. https://doi.org/10.1787/agr_outlook-2018-en

OECD, and FAO. (2019a). OECD-FAO Agricultural Outlook 2019-2028. OECD Publishing, Paris/Food and Agriculture Organization of the United Nations, Rome. https://doi.org/10.1787/agr_outlook-2019-en

OECD, and FAO. (2019b). OECD-FAO Agricultural Outlook (Edition 2019), OECD Agriculture Statistics (database). https://doi.org/https://doi.org/10.1787/eed409b4-en

Papageorgiou, T., Michaelides, P. G., and Milios, J. G. (2010). Business cycles synchronization and clustering in Europe (1960-2009). Journal of Economics and Business, 62(5), 419-470. https://doi.org/10.1016/j.jeconbus.2010.05.004

Pashigian, B. P. (1970). Rational Expectations and the Cobweb Theory. Journal of Political Economy, 78(2), 338-352. https://www.jstor.org/stable/pdf/1830693.pdf

PIC. (2012). Análisis de la Industria Porcina en Latinoamérica, (9), 40. http://www.piclatam.com/news/galeria/upload/documentos/tQEYFq_Benchmark Latam, Febrero 2015.pdf

Plain, R. L., and Williams, J. E. (1981). Aaptative Planning under Price Uncertainity in Pork Production. Southern Journal of Agricultural Economics, 13(2), 39-46. http://purl.umn.edu/30121

Prieto, R. L., Melo, Ó., Díaz, L. G., Riveros, J. L., and Fernández, J. (2018). Industria de la carne bovina y ovina chilena al 2030: principales desafios tecnológicos para mejorar su competitividad (Serie Estu.). Santiago-Chile: Fundación para la Innovación Agraria. http://www.fia.cl/wp-content/uploads/2019/01/Libro_Carne_Bovina_Ovina.pdf

ProChile. (2013). Estudio de mercado. Carne de cerdo en Uruguay. Santiago-Chile.

Quiroz, I., Hernández, J., Perdomo, D., and Lafferty, L. (2018). Análisis de cadenas agroalimentarias en Chile y oportunidades por el uso de tecnologías limpias por PYMES. Santiago, Chile. https://www.ctc-n.org/system/files/dossier/3b/reporte_4.pdf

Rivas Rios, L., Seré Rabé, C., Sanint, L. R., and Cordeu, J. L. (1989). La demanda de carnes en países seleccionados de América Latina y el Caribe: proyecto colaborativo FAORLAC/CIAT. (CIAT \& FAO, Eds.). Cali: CIAT Books, Manuals and Guides. http://hdl.handle.net/10568/54106

Rodríguez Benavides, D., Lima Santiago, V., and Ortiz, E. (2015). ¿Sincronizaron México y Estados Unidos sus ciclos económicos con el TLCAN? Contaduria y Administracion, 60, 195-229. https://doi.org/10.1016/j.cya.2015.08.010

Rojas, C. (2019). Comportamiento y caracterización de la producción de ganado bovino en Chile (No. Nr.2, June 2019). Santiago, Chile. https://www.ine.cl/docs/defaultsource/documentos-de-trabajo/económicos/caracterizacion-produccion-carne-bovina-enchile-ine.pdf?sfvrsn=3c345cd2_0

Rose, A., and Engel, C. (2002). Currency Unions and International Integration. Journal of 
Money, Credit, and Banking, 34(4), 1067-1089. https://doi.org/10.1353/mcb.2002.0058

Rossen, A. (2015). What are metal prices like? Co-movement, price cycles and long-run trends. Resources Policy, 45(6), 255-276.

https://doi.org/10.1016/j.resourpol.2015.06.002

Schüttel, C., Kleinwechter, U., Ihle, R., and Grethe, H. (2011). Domestic policy responses to the food price crisis: The case of Bolivia. Journal of Agriculture and Rural Development in the Tropics and Subtropics, 112(2), 125-139.

Shonkwiler, J. S., and Spreen, T. H. (1986). Statistical Significance and Stability of the Hog Cycle. Journal of Agricultural and Applied Economics, 18(02), 227-234. https://doi.org/10.1017/S0081305200006270

Siedschlag, I. (2010). Patterns and determinants of business cycle synchronization in the enlarged European Economic and Monetary Union. Eastern Journal of European Studies, 1(1), 21-44.

https://search.proquest.com/openview/5be8fc9545f55fc0b41a0dc6b47b60f0/1?cbl=2049 087\&pq-origsite $=$ gscholar

Silva, J. F., and Flake, O. (2018). Brazil. Livestock and Products Annual. Annual. Livestock 2018 (No. BR 1814).

Stockton, M. C., Tassell, L. W. Van, and Stockton, M. C. (2007). The Cattle Price Cycle : An Exploration in Simulation. In NCR-134 Conference on Applied Commodity Price Analysis, Forecasting, and Market Risk Management. Chicago. http://ageconsearch.umn.edu/bitstream/37564/2/confp09-07.pdf

Subervie, J. (2008). The variable response of agricultural supply to world price instability in developing countries. Journal of Agricultural Economics, 59(1), 72-92. https://doi.org/10.1111/j.1477-9552.2007.00136.x

Talpaz, H. (1974). Multi-Frequency Cobweb Model: Decomposition of the Hog Cycle. American Journal of Agricultural Economics, 56(1), 38-49. https://doi.org/10.2307/1239345

The Economist. (2007). The end of cheap food. The Economist. https://www.economist.com/leaders/2007/12/06/the-end-of-cheap-food

Tigchelaar, M., Battisti, D. S., Naylor, R. L., and Ray, D. K. (2018). Future warming increases probability of globally synchronized maize production shocks. Proceedings of the National Academy of Sciences of the United States of America, 115(26), 6644-6649. https://doi.org/10.1073/pnas.1718031115

Tomek, W. G., and Kaiser, H. M. (2014). Agricultural Product Prices (5th ed.). Ithaca, United States: Cornell University Library.

Twine, E. E., Rude, J., and Unterschultz, J. (2016). Canadian Cattle Cycles and Market Shocks. Canadian Journal of Agricultural Economics/Revue canadienne d'agroeconomie, 64(1), 119-146. https://doi.org/10.1111/cjag.12066

Uruguay XXI. (2011). Sector Porcino en Uruguay. Promoción de inversiones y exportaciones. República Oriental del Uruguay. Montevideo-Uruguay. https://www.uruguayxxi.gub.uy/es/centro-informacion/articulo/industria-porcina/

Waelti, S. (2005). The macroeconomic determinants of stock market synchronization. Journal of International Banking Law, 11.10(October 2015), 436-441.

https://doi.org/10.1227/01.NEU.0000349921.14519.2A 
Wiggins, S., Keats, S., and Compton, J. (2010). What caused the food price spike of 2007 / 08? Lessons for world cereals markets. Food Prices Project Report. London.

https://www.odi.org/sites/odi.org.uk/files/odi-assets/publications-opinion-files/6103.pdf

World Bank Group. (2018). Food Price Watch.

http://www.worldbank.org/en/topic/poverty/publication/food-price-watch-home.

Accessed 11 May 2018 


\section{Appendices}

Table A. 1 Per capita consumption of meat 2016 selected LAC countries, USA and world

\begin{tabular}{lccccc}
\hline & $\begin{array}{c}\text { Beef } \\
\mathbf{k g} / \mathbf{h d}\end{array}$ & $\begin{array}{c}\text { Pork } \\
\mathbf{k g} / \mathbf{h d}\end{array}$ & $\begin{array}{c}\text { Poultry } \\
\mathbf{k g} / \mathbf{h d}\end{array}$ & $\begin{array}{c}\text { Sheep meat } \\
\mathbf{k g} / \mathbf{h d}\end{array}$ & $\begin{array}{c}\text { Meat total* } \\
\mathbf{~ k g} / \mathbf{h d}\end{array}$ \\
\cline { 2 - 6 } Argentina & 41.4 & 8.3 & 36.6 & 1.2 & 87.5 \\
Uruguay & 46.7 & 14.4 & 13.7 & 5.7 & 80.5 \\
Brazil & 25.5 & 12 & 40.5 & 0.4 & 78.4 \\
Chile & 15.1 & 17.6 & 31 & 0.4 & 64.1 \\
Mexico & 8.8 & 11.6 & 26.5 & 0.5 & 47.4 \\
LAC & 17 & 9.5 & 31.9 & 0.5 & 58.9 \\
USA & 25 & 22.9 & 48.5 & 0.4 & 96.8 \\
World & 6.5 & 12.4 & 13.7 & 1.7 & 34.3 \\
\hline
\end{tabular}

Source: ECLAC et al. (2017).

* Fish is not considered

Table A. 2 Pig and cattle country production, consumption, exports and imports in 2017

\begin{tabular}{|c|c|c|c|c|c|c|}
\hline Pork (tonnes) & \multicolumn{2}{|c|}{ Brazil } & \multicolumn{2}{|c|}{ Chile } & \multicolumn{2}{|c|}{ Uruguay } \\
\hline Production & $3,840,500$ & $100 \%$ & 489,097 & $100 \%$ & 11,839 & $100 \%$ \\
\hline Imports & 1680 & $<1 \%$ & 122,611 & $25 \%$ & 31,709 & $268 \%$ \\
\hline Consumption & $3,237,150$ & $84 \%$ & 449,268 & $92 \%$ & 43,504 & $367 \%$ \\
\hline Exports & 605,030 & $16 \%$ & 162,440 & $33 \%$ & 44 & $<1 \%$ \\
\hline \multicolumn{7}{|l|}{$\begin{array}{l}\text { Beef and veal } \\
\text { (tonnes) }\end{array}$} \\
\hline Production & $8,923,300$ & $100 \%$ & 204,752 & $100 \%$ & 594,122 & $100 \%$ \\
\hline Imports & 40,400 & $<1 \%$ & 263,835 & $129 \%$ & 4,217 & $1 \%$ \\
\hline Consumption & $7,533,490$ & $84 \%$ & 453,791 & $222 \%$ & 304,899 & $51 \%$ \\
\hline Exports & $1,430,210$ & $16 \%$ & 14,796 & $7 \%$ & 293,440 & $49 \%$ \\
\hline
\end{tabular}

Source: Brazil and Chile data OECD and FAO, (2019b), Uruguay data http://www.fao.org/faostat/en/\#data/TP . 
Table A. 3 Summary of pig and cattle production chain in Brazil, Chile and Uruguay

\begin{tabular}{|c|c|c|c|c|c|c|}
\hline & $\begin{array}{c}\text { Brazil Pig } \\
\text { BP } \\
\end{array}$ & $\begin{array}{c}\text { Chile Pig } \\
\text { CP }\end{array}$ & $\begin{array}{c}\text { Uruguay Pig } \\
\text { UP }\end{array}$ & $\begin{array}{c}\text { Brazil Cattle } \\
\text { BC } \\
\end{array}$ & $\begin{array}{c}\text { Chile Cattle } \\
\text { CC } \\
\end{array}$ & $\begin{array}{c}\text { Uruguay Cattle } \\
\text { UC }\end{array}$ \\
\hline $\begin{array}{l}\text { Domestic } \\
\text { consump- } \\
\text { tion (\% of } \\
\text { produc- } \\
\text { tion) }\end{array}$ & $84 \%$ & $92 \%$ & $367 \%$ & $84 \%$ & $222 \%$ & $51 \%$ \\
\hline Imports & $\begin{array}{l}\text { Few imports }(0.04 \% \text { of } \\
\text { production) }\end{array}$ & $\begin{array}{l}25 \% \text { mainly from Bra- } \\
\text { zil }\end{array}$ & $\begin{array}{l}268 \% \text { of production is } \\
\text { imported ( } 61 \% \text { mainly } \\
\text { produced in Brazil and } \\
\text { Chile) }\end{array}$ & $0.5 \%$ of production & $\begin{array}{l}129 \% \text { of production, } \\
\text { imported from Para- } \\
\text { guay, Brazil and Ar- } \\
\text { gentina }\end{array}$ & $1 \%$ of production \\
\hline Exports & $\begin{array}{l}16 \% \text { of production to } \\
\text { China, Hong Kong }\end{array}$ & $\begin{array}{l}33 \% \text { of production to } \\
\text { Japan, South Korea, } \\
\text { Russia and China }\end{array}$ & Few exports & $\begin{array}{l}16 \% \text { of production to } \\
\text { Hong Kong, China, } \\
\text { Egypt, Russia, Iran, } \\
\text { Chile, Italy, Saudi Ara- } \\
\text { bia, Singapore and the } \\
\text { Netherlands }\end{array}$ & $7 \%$ & $\begin{array}{l}49 \% \text { of production to } \\
\text { China, USA and Israel }\end{array}$ \\
\hline $\begin{array}{l}\text { Main pro- } \\
\text { duction re- } \\
\text { gion }\end{array}$ & $\begin{array}{l}\text { Whole country (south } \\
60 \% \text { of the pigs) }\end{array}$ & $\begin{array}{l}\text { VI region (O'Higgins } \\
\text { region, } 84 \% \text { of produc- } \\
\text { tion) }\end{array}$ & $\begin{array}{l}\text { Central-south ( } 45 \% \text { of } \\
\text { total production), west } \\
\text { and east represent the } \\
55 \% \text { of total production }\end{array}$ & $\begin{array}{l}\text { Cattle for slaughter is } \\
\text { distributed in the five } \\
\text { regions in Brazil; fo- } \\
\text { cusing mainly on the } \\
\text { central west, north and } \\
\text { southeast regions, these } \\
\text { three regions concen- } \\
\text { trated } 79 \% \text { of the pro- } \\
\text { duction for slaughter } \\
\text { by } 2013\end{array}$ & $\begin{array}{l}\text { Bovine production is } \\
\text { distributed throughout } \\
\text { the country. It is con- } \\
\text { centrated }(76 \%) \text { in the } \\
\text { south of Chile, Bío-Bío } \\
\text { region to Los Lagos. } \\
\text { The Bio-Bio region } \\
\text { houses } 11 \% \text { of the cat- } \\
\text { tle, Araucanía } 14 \% \text {, } \\
\text { Los Ríos } 18 \% \text { and Los } \\
\text { Lagos } 33 \% \text {. }\end{array}$ & $\begin{array}{l}\text { Bovine production is } \\
\text { distributed throughout } \\
\text { the country. }\end{array}$ \\
\hline $\begin{array}{l}\text { Charac- } \\
\text { teristics of } \\
\text { production }\end{array}$ & $\begin{array}{l}\text { South ( } 45 \% \text { integrated, } \\
37 \% \text { cooperated), }\end{array}$ & $\begin{array}{l}\text { High vertical integra- } \\
\text { tion and concentrated } \\
\text { in few producers }(94 \%\end{array}$ & $\begin{array}{l}\text { Seven farms control } \\
35 \% \text { of production with } \\
\text { more than } 500 \text { pigs, }\end{array}$ & $\begin{array}{l}\text { Diverse production } \\
\text { systems adjusted to the } \\
\text { different biomass and }\end{array}$ & $\begin{array}{l}\text { Breeders dedicated to } \\
\text { the nursing of calves } \\
\text { have different sales }\end{array}$ & $\begin{array}{l}\text { Extensive livestock } \\
\text { farming predominates, } \\
\text { intensive livestock }\end{array}$ \\
\hline
\end{tabular}




\begin{tabular}{|c|c|c|c|c|c|c|}
\hline & $\begin{array}{l}\text { Brazil Pig } \\
\text { BP }\end{array}$ & $\begin{array}{c}\text { Chile Pig } \\
\text { CP }\end{array}$ & $\begin{array}{c}\text { Uruguay Pig } \\
\text { UP }\end{array}$ & $\begin{array}{c}\text { Brazil Cattle } \\
\text { BC }\end{array}$ & $\begin{array}{c}\text { Chile Cattle } \\
\text { CC }\end{array}$ & $\begin{array}{c}\text { Uruguay Cattle } \\
\text { UC }\end{array}$ \\
\hline & $\begin{array}{l}\text { southeast ( } 82 \% \text { inde- } \\
\text { pendent and } 18 \% \text { inte- } \\
\text { grated), midwest ( } 45 \% \\
\text { independent, } 50 \% \text { inte- } \\
\text { grated and } 5 \% \text { coopera- } \\
\text { tive), northeast and } \\
\text { north ( } 100 \% \text { independ- } \\
\text { ent). South production } \\
\text { with a high segregation } \\
\text { of production in multi- } \\
\text { ple stages }\end{array}$ & $\begin{array}{l}\text { of domestic production } \\
\text { in } 25 \text { producers). } 75 \% \\
\text { of production is con- } \\
\text { centrated in five large } \\
\text { packers }\end{array}$ & $\begin{array}{l}24 \% \text { of farms have be- } \\
\text { tween } 50 \text { and } 499 \text { pigs, } \\
\text { and } 34 \% \text { of farms have } \\
\text { between } 5 \text { and } 49 \text { pigs. } \\
\text { Three types of produc- } \\
\text { tion systems: breeding } \\
\text { ( } 77 \% \text { of the total), win- } \\
\text { tering ( } 4 \% \text { ) and full cy- } \\
\text { cle }(19 \%)\end{array}$ & $\begin{array}{l}\text { sociocultural aspects of } \\
\text { farmers in each area. } \\
\text { There is an absence of } \\
\text { standardization of pro- } \\
\text { duction processes and } \\
\text { animals for slaughter. } \\
\text { Feeding is based on } \\
\text { natural and sown pas- } \\
\text { tures. Some producers } \\
\text { complete the whole cy- } \\
\text { cle (breeding, nursery } \\
\text { and fattening) while } \\
\text { others specialize in } \\
\text { each phase }\end{array}$ & $\begin{array}{l}\text { markets. One the fat- } \\
\text { tening for male cattle } \\
\text { and the other female } \\
\text { cattle for milk produc- } \\
\text { tion. The fattening pro- } \\
\text { cess can be extensive } \\
\text { or intensive. }\end{array}$ & $\begin{array}{l}\text { gained space in recent } \\
\text { years, due to the in- } \\
\text { crease in the price of } \\
\text { land. Three production } \\
\text { phases, breeding uses } \\
\text { natural pastures, nurs- } \\
\text { ing (rearing) and fat- } \\
\text { tening (invernadas) is } \\
\text { done in on artificial } \\
\text { grasslands, winter } \\
\text { greens and supplemen- } \\
\text { tation. Complete cycles } \\
\text { are also carried out. }\end{array}$ \\
\hline Breed used & No information & No information & No information & $\begin{array}{l}\text { Zebu cattle located in } \\
\text { the central west and } \\
\text { north of the country. In } \\
\text { the south taurine races } \\
\text { and crosses with zebu } \\
\text { races are used. slaugh- } \\
\text { ter herds are mainly } \\
\text { composed of zebu, a } \\
\text { double purpose race. } \\
\text { Rio grande do sul state } \\
\text { production is more in- } \\
\text { tensive based on here- } \\
\text { ford, angus, braford } \\
\text { and brangus. }\end{array}$ & $\begin{array}{l}\text { Mostly correspond to } \\
\text { dual-purpose breeds, } \\
\text { overo colorado } 19 \% \\
\text { (clavel alemán) and } \\
\text { overo negro } 8 \% \text { (hol- } \\
\text { ando europeo - euro- } \\
\text { pean). The meat breeds } \\
\text { are mainly composed } \\
\text { of angus (14\%), here- } \\
\text { ford ( } 4 \% \text { ) and other } \\
\text { breeds for meat ( } 2 \% \text { ) }\end{array}$ & $\begin{array}{l}\text { British breeds (hereford } \\
\text { and angus, predomi- } \\
\text { nates }(80 \%) \text {, continen- } \\
\text { tal and crosses (charo- } \\
\text { lais and limousin) and } \\
\text { the indian races and } \\
\text { crosses (braford and } \\
\text { brangus) }\end{array}$ \\
\hline
\end{tabular}




\begin{tabular}{|c|c|c|c|c|c|c|}
\hline & $\begin{array}{c}\text { Brazil Pig } \\
\text { BP }\end{array}$ & $\begin{array}{c}\text { Chile Pig } \\
\text { CP }\end{array}$ & $\begin{array}{c}\text { Uruguay Pig } \\
\text { UP }\end{array}$ & $\begin{array}{c}\text { Brazil Cattle } \\
\text { BC }\end{array}$ & $\begin{array}{c}\text { Chile Cattle } \\
\text { CC }\end{array}$ & $\begin{array}{c}\text { Uruguay Cattle } \\
\text { UC }\end{array}$ \\
\hline $\begin{array}{l}\text { Comercia- } \\
\text { lization }\end{array}$ & $\begin{array}{l}\text { Direct to slaughter- } \\
\text { houses, vertical inte- } \\
\text { grated slaughterhouses } \\
\text { or slaughter coopera- } \\
\text { tives }\end{array}$ & $\begin{array}{l}\text { Direct to slaughter- } \\
\text { houses, vertical inte- } \\
\text { grated }\end{array}$ & $\begin{array}{l}\text { Domestic commerciali- } \\
\text { zation through interme- } \\
\text { diaries, consignees and } \\
\text { fairs }\end{array}$ & $\begin{array}{l}\text { Done mainly in con- } \\
\text { centrating markets. In- } \\
\text { ternet and television } \\
\text { channels for the com- } \\
\text { mercialization of the } \\
\text { cattle on farm. Greatest } \\
\text { commercialization oc- } \\
\text { curs in the south-cen- } \\
\text { tral zone of Brazil (ap- } \\
\text { proximately } 76 \% \text { ) }\end{array}$ & $\begin{array}{l}\text { Transactions occur } \\
\text { mostly through open } \\
\text { markets and fairs. Cat- } \\
\text { tle transactions via auc- } \\
\text { tion occurs mainly in } \\
\text { the southern zone. } \\
\text { Transactions between } \\
\text { the fattening and } \\
\text { slaughter phase can be } \\
\text { done directly. }\end{array}$ & $\begin{array}{l}\text { Animals are sold three } \\
\text { times during their life. } \\
\text { The commercialization } \\
\text { for replacement is car- } \\
\text { ried out by screen } \\
\text { through intermediaries, } \\
\text { consignees, while for } \\
\text { slaughter it is marketed } \\
\text { through desks (con- } \\
\text { signees) which agree } \\
\text { with the plants or } \\
\text { through direct sale }\end{array}$ \\
\hline $\begin{array}{l}\text { Slaughter- } \\
\text { houses }\end{array}$ & $\begin{array}{l}110 \text { slaughterhouses } \\
\text { registered. BRF (28\% } \\
\text { market share), JBS } \\
(14 \%), \text { Aurora (14\%), } \\
\text { Frimesa (5\%), Alibem } \\
(5 \%) \text { and others (34\%) }\end{array}$ & $\begin{array}{l}141 \text { slaughterhouses } \\
\text { with } 68 \% \text { in the IV re- } \\
\text { gion. }\end{array}$ & $\begin{array}{l}10 \text { qualified slaughter } \\
\text { companies; four of } \\
\text { them also dedicated to } \\
\text { the production of sau- } \\
\text { sages. } 78 \% \text { of the na- } \\
\text { tional processing ca- } \\
\text { pacity is concentrated } \\
\text { in two companies. In- } \\
\text { dustry prefers to import } \\
\text { frozen product, lower } \\
\text { costs, }\end{array}$ & $\begin{array}{l}\text { Processing industry } \\
\text { dominated by three in- } \\
\text { ternational companies: } \\
\text { JBS, Marfrig and Mi- } \\
\text { nerva. At state level } \\
\text { (province) there are } \\
\text { many slaughterhouses } \\
\text { that operate in limited } \\
\text { domestic markets }\end{array}$ & $\begin{array}{l}\text { Slaughter of cattle is } \\
\text { carried out mainly in } \\
\text { the regions of Los La- } \\
\text { gos, Araucanía and } \\
\text { Metropolitana, four } \\
\text { largest slaughterhouses } \\
\text { in the country control } \\
54 \% \text { of the processing. } \\
\text { Lo Valledor holding } \\
\text { company (AASA) pro- } \\
\text { cesses almost } 40 \% \text { of } \\
\text { cattle }\end{array}$ & $\begin{array}{l}37 \text { slaughterhouses in } \\
\text { the country, which pro- } \\
\text { cess } 99 \% \text { of the slaugh- } \\
\text { ter of cattle, } 23 \text { are au- } \\
\text { thorized to export. } \\
\text { Concentrated in the } \\
\text { south, (departments of } \\
\text { Canelones and Monte- } \\
\text { video, } 75 \% \text { of the total } \\
\text { work). Four firms } \\
\text { slaughter } 56 \% \text {. Foreign } \\
\text { investment in slaugh- } \\
\text { terhouses accounts for } \\
54 \% \text { of total slaughter }\end{array}$ \\
\hline
\end{tabular}

Source: Authors. 


\section{A.1 Theoretical background}

A price cycle is - in the absence of external influences - caused by the inability to immediately adapt supply in reaction to a price shock caused by demand (Ezekiel, 1938). The magnitude of the price elasticity of supply relative to the magnitude of the price elasticity of demand in the relevant sections of the supply and demand functions respectively, determines the temporal development of the price cycle amplitude. Figures A.1 to A.3 outlines the three potential types of this temporal development, known as the cobweb theorem: i) converging to an equilibrium price, ii) staying constant or iii) diverging. This economic model explains the periodic agricultural price cycles based on the lagged supply reaction due to biological production constraints.

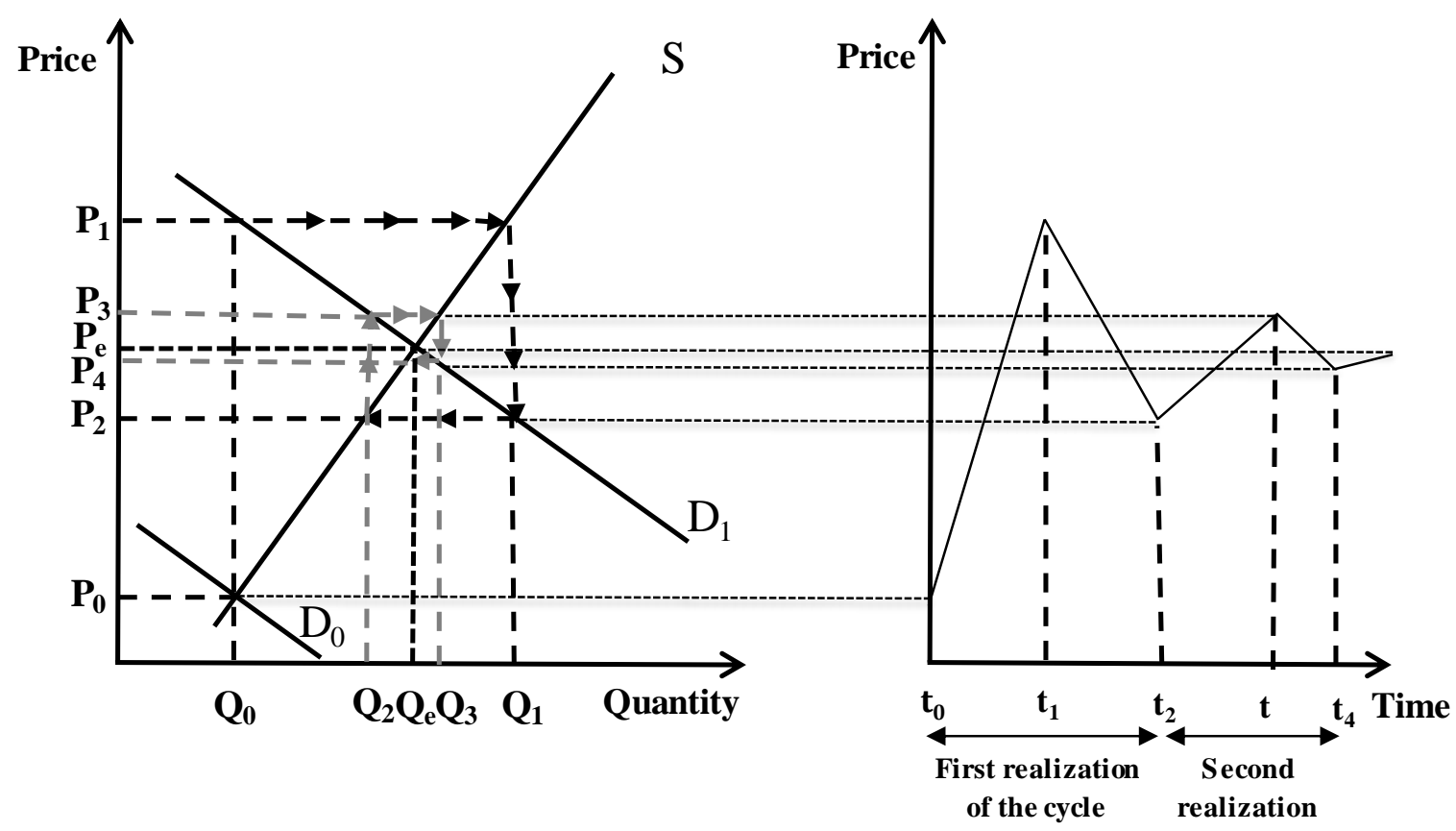

\section{Figure A. 1 Convergent price cycle amplitude}

Source: Authors based on Goodwin (1994, pp. 158).

In Figure A.1, a convergent cycle results because of the demand elasticity being in absolute terms larger than the supply elasticity. The starting equilibrium point at $\mathrm{Q}_{0}$ and $\mathrm{P}_{0}$ is disturbed by an exogenous shock moving the demand curve from $D_{0}$ to $D_{1}$. Consequently, the new equilibrium price increases from $\mathrm{P}_{0}$ to $\mathrm{P}_{1}$. With a naive expectation that prices are going to stay high in the future, producers increase their production to $\mathrm{Q}_{1}$. If this increase in production is entirely sold to the domestic market (assuming no international trade), domestic prices collapse to $\mathrm{P}_{2}$. As a result, supply shrinks from $\mathrm{Q}_{1}$ to $\mathrm{Q}_{2}$ at price $\mathrm{P}_{2}$. As $\mathrm{P}_{2}$ is much lower than $\mathrm{P}_{1}$, producers decide to reduce production for the next production cycle. $\mathrm{P}_{2}$ also marks the start of 
the second realization of the cycle. The reduction in supplied quantity from $\mathrm{Q}_{1}$ to $\mathrm{Q}_{2}$ causes the price to increase to $\mathrm{P}_{3}$ in the next period (in the absence of international trade), and the pattern continues as previously described. This way, the price converges slowly to the equilibrium price $\mathrm{P}_{\mathrm{e}}$ at which the equilibrium quantity $\mathrm{Q}_{\mathrm{e}}$ will be supplied and demanded. This equilibrium is achieved due to the diminishing amplitude of subsequent realizations of the price cycle. In an identical fashion, constant and explosive cycle amplitudes result from the cases shown in Figures A.2 and A.3, respectively.

Figure A.2 shows a constant cycle amplitude resulting from supply elasticity and demand elasticity being equal in absolute terms. The peak and trough prices, and therefore the cycle amplitude, stay constant over time. This constant cycle appears for goods for which a price change results in identical percentage changes in demand and supply.

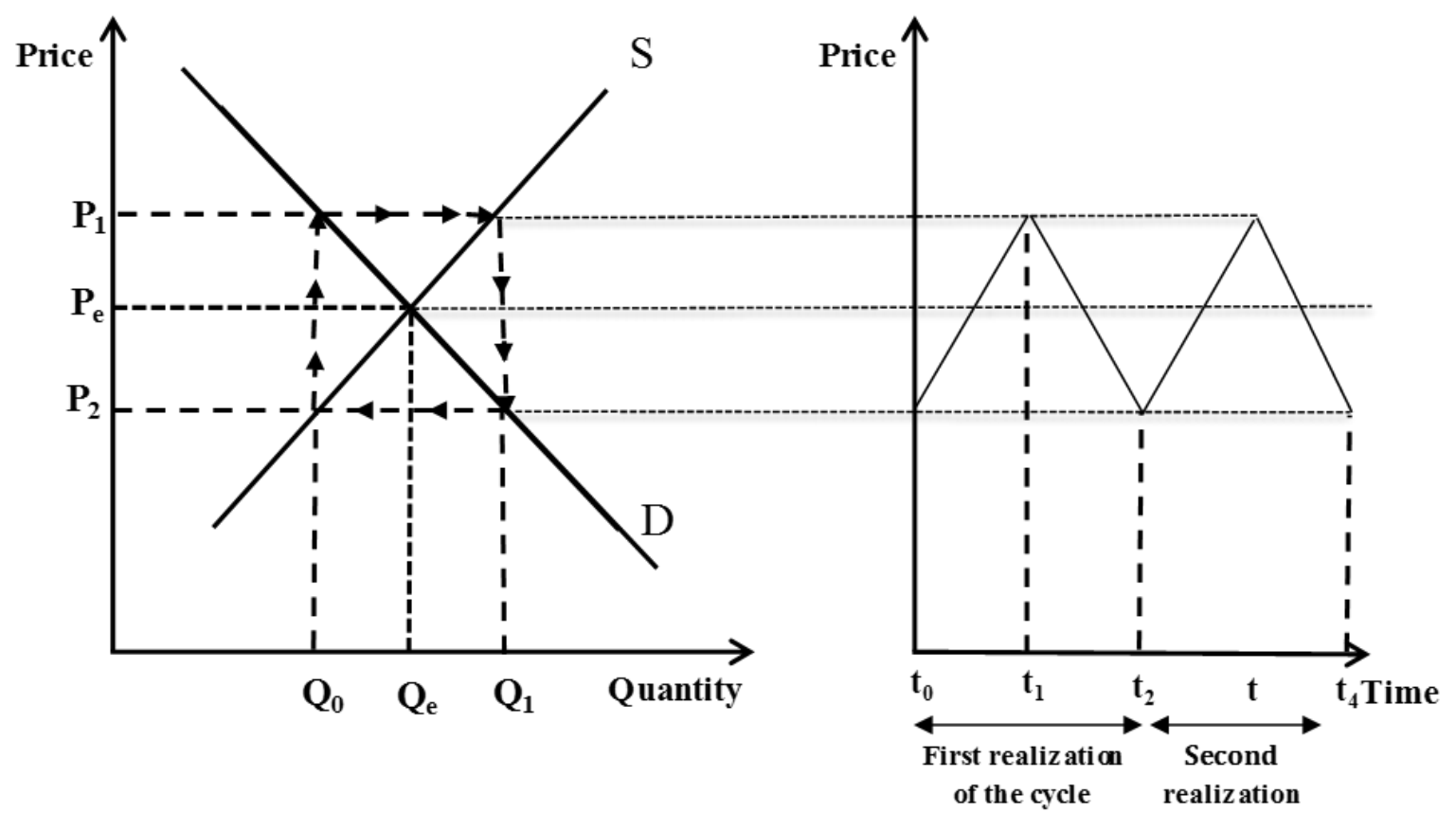

Figure A. 2 Constant price cycle amplitude

Source: Authors based on Goodwin (1994, pp. 158).

Figure A.3 illustrates an explosive cycle amplitude: The peak and trough prices increase over time. Such a pattern occurs when the magnitude of the demand elasticity is smaller in absolute terms than the magnitude of the supply elasticity. The elastic supply elasticity occurs when a price change results in a large change in supplied quantities. 


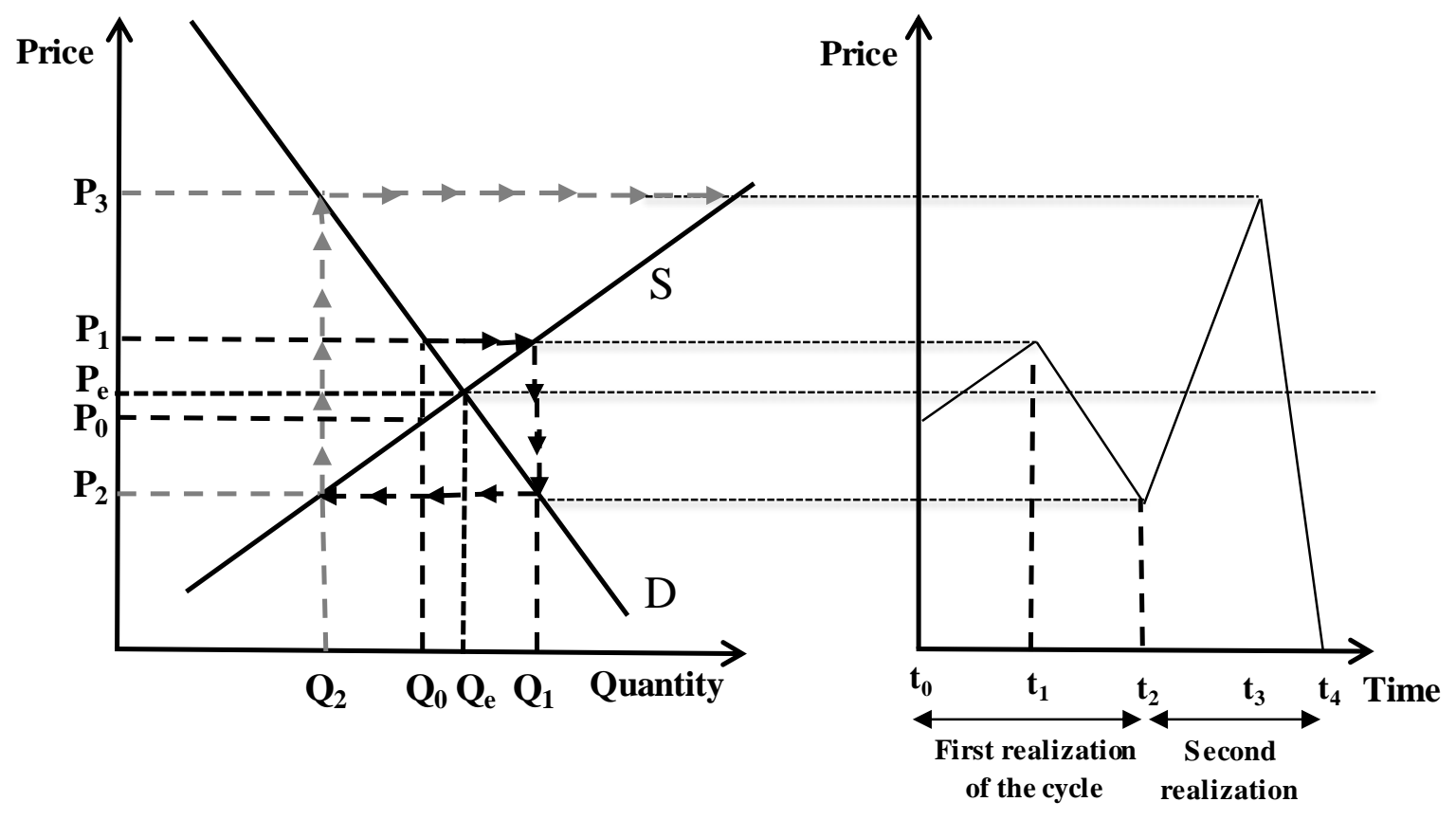

Figure A. 3 Explosive price cycle amplitude

Source: Authors based on Goodwin (1994, pp. 158). 


\section{A.2 Empirical evidence}

Table A. 4 Price cycle lengths and used methodology by commodity, country and period

\begin{tabular}{|c|c|c|c|c|c|}
\hline Commodity & Country & Period & $\begin{array}{c}\text { Cycle length } \\
\text { (month) }\end{array}$ & Method & Source \\
\hline Pork & USA & $\begin{array}{l}1949-1965 \\
1969-1985\end{array}$ & $\begin{array}{l}84,48 \\
\text { and } 36\end{array}$ & $\begin{array}{l}\text { Time series analysis } \\
\text { (ARIMA) }\end{array}$ & $\begin{array}{l}\text { Shonkwiler and Spreen } \\
\text { (1986) }\end{array}$ \\
\hline Pork & USA & 1910-2004 & 60 to 36 & $\begin{array}{l}\text { TV-STAR } \\
\text { time-varying smooth } \\
\text { transition autoregressive } \\
\text { model }\end{array}$ & Holt and Craig (2006) \\
\hline Pork & $\begin{array}{l}\text { Great Bri- } \\
\text { tain }\end{array}$ & $1921-1933$ & 48 & Visual inspection & $\begin{array}{l}\text { Coase and Fowler } \\
\text { (1935) }\end{array}$ \\
\hline $\begin{array}{l}\text { Pork (Hog- } \\
\text { Corn } \\
\text { price ratio) }\end{array}$ & USA & 1964-1971 & 48 & $\begin{array}{l}\text { Harmonic analysis- } \\
\text { Multi-Frequency Cob- } \\
\text { web Model }\end{array}$ & Talpaz (1974) \\
\hline $\begin{array}{l}\text { Pork }(\mathrm{Hog}- \\
\text { Corn price ra- } \\
\text { tio) }\end{array}$ & USA & $1952-1968$ & 48 & $\begin{array}{l}\text { Harmonic analysis, Or- } \\
\text { dinary Least Squared }\end{array}$ & Jelavich (1973) \\
\hline Pork & USA & $1925-1959$ & 48 & Visual inspection & Harlow (1960) \\
\hline Pork & USA & 1974-2009 & 48 & Hodrick-Prescott-Filter & $\begin{array}{l}\text { Holst and von Cramon- } \\
\text { Taubadel (2012) }\end{array}$ \\
\hline Pork & Germany & 1896-1914 & 48 to 36 & Visual inspection & Hanau (1928) \\
\hline Pork & Canada & $1949-1972$ & 48 to 36 & Harmonic analysis & $\begin{array}{l}\text { Kulshreshtha and } \\
\text { Wilson (1973) }\end{array}$ \\
\hline Pork & Germany & 1974-2008 & 45 & Hodrick-Prescott-Filter & $\begin{array}{l}\text { Holst and von Cramon- } \\
\text { Taubadel (2012) }\end{array}$ \\
\hline Pork & China & 1996- 2009 & 42 & $\begin{array}{l}\text { Seasonal Adjustment; } \\
\text { Hodrick-Prescott, Band } \\
\text { Pass Filter Method }\end{array}$ & Fengying et al. (2009) \\
\hline Pork & USA & 1970-1979 & 33 & Harmonic analysis & $\begin{array}{l}\text { Plain and Williams } \\
\text { (1981) }\end{array}$ \\
\hline Cattle & Argentina & 1937-1993 & 72 & Spectral decomposition & $\begin{array}{l}\text { Mundlak and Huang } \\
\text { (1996) }\end{array}$ \\
\hline Cattle & Canada & 1988-2011 & 132 & Spectral decomposition & Twine et al. (2016) \\
\hline Cattle & Canada & 1949-1972 & 114 & Harmonic analysis & $\begin{array}{l}\text { Kulshreshtha and } \\
\text { Wilson (1973) }\end{array}$ \\
\hline Cattle & Uruguay & 1924-1993 & 72 & Spectral decomposition & $\begin{array}{l}\text { Mundlak and Huang } \\
\text { (1996) }\end{array}$ \\
\hline Cattle & USA & 1909-2006 & 123 & $\begin{array}{l}\text { Harmonic model and } \\
\text { AIC criterion }\end{array}$ & Stockton et al. (2007) \\
\hline Cattle & USA & 1930-1999 & 122 & $\begin{array}{l}\text { Generalized method of } \\
\text { moments (GMM) }\end{array}$ & Aadland (2004) \\
\hline Cattle & USA & 1930-1991 & 120 & Spectral decomposition & $\begin{array}{l}\text { Mundlak and Huang } \\
\text { (1996) }\end{array}$ \\
\hline Cattle & USA & 1921-1969 & 120 & Fourier Theorem & Franzmann (1971) \\
\hline
\end{tabular}

Source: Authors. 


\section{A.3 Data}

Table A. 5 Data sources

\begin{tabular}{|c|c|c|c|c|c|c|}
\hline & Country & Element & $\begin{array}{l}\text { Original cur- } \\
\text { rency }\end{array}$ & Description & $\begin{array}{l}\text { Transformed } \\
\text { currency } \\
\text { (CPI, base } \\
\text { year 2000/1) }\end{array}$ & Data source \\
\hline \multirow[t]{3}{*}{$\begin{array}{l}\text { Pig pro- } \\
\text { ducer pri- } \\
\text { ces }\end{array}$} & Brazil & $\begin{array}{l}\text { Preço médio - recebido pelo } \\
\text { agricultor - suínos - comuns - kg } \\
\text { - PR - R\$ - Secretaria da } \\
\text { Agricultura e do Abastecimento } \\
\text { do Estado do Paraná, } \\
\text { Departamento de Economia Rural } \\
\text { (Seab-PR) - ERAL12_PRSUC12 }\end{array}$ & $\begin{array}{l}\text { Reales }(\mathrm{R} \$), \\
\text { nominal prices }\end{array}$ & $\begin{array}{l}\text { Monthly ordinary pig producer } \\
\text { price, } \mathrm{R} \$ / \mathrm{kg} \text {, live, farm deliv- } \\
\text { ery, Parana State. Between } 80 \\
\text { and } 120 \mathrm{~kg} \text {. }\end{array}$ & $\begin{array}{l}\text { Reales }(\mathrm{R} \$) \\
\text { real prices }\end{array}$ & $\begin{array}{l}\text { IPEA. Institute for Applied Eco- } \\
\text { nomic Research with data of the } \\
\text { Agriculture and Supply Service } \\
\text { of Parana State (Seab) }\end{array}$ \\
\hline & Chile & $\begin{array}{l}\text { Precios a productor de Cerdo de } \\
\text { consumo s/e } \$ / \text { kilo (Pesos } \\
\text { nominales sin IVA) }\end{array}$ & $\begin{array}{l}\text { Chilean pesos } \\
(\mathrm{Ch} \$), \text { nomi- } \\
\text { nal prices }\end{array}$ & $\begin{array}{l}\text { Monthly pig producer price, } \\
\$ / \mathrm{kg} \text {, live, Tattersal Santiago } \\
\text { livestock auction prices }\end{array}$ & $\begin{array}{l}\text { Chilean pesos } \\
(\mathrm{Ch} \$), \text { real } \\
\text { prices }\end{array}$ & $\begin{array}{l}\text { ODEPA. Agriculture policy and } \\
\text { research bureau (Oficina de } \\
\text { Estudios y Políticas Agrarias) }\end{array}$ \\
\hline & Uruguay & $\begin{array}{l}\text { UYA373551 Cerdos Gordos y } \\
\text { Cachorros (U\$S/kg) }\end{array}$ & Dollar (USD) & $\begin{array}{l}\text { Monthly farm prices of fed pig, } \\
\text { US } \$ / \mathrm{kg} \text {, live, slaughterhouse } \\
\text { delivered }\end{array}$ & $\begin{array}{l}\text { Uruguayan } \\
\text { pesos (Ur\$), } \\
\text { real prices }\end{array}$ & $\begin{array}{l}\text { INAC. National meat institute } \\
\text { (Instituto Nacional de la carne) }\end{array}$ \\
\hline \multirow[t]{3}{*}{$\begin{array}{l}\text { Cattle } \\
\text { producer } \\
\text { prices }\end{array}$} & Brazil & $\begin{array}{l}\text { Preço médio - recebido pelo } \\
\text { agricultor - boi gordo - arroba - } \\
\text { PR - R\$ - Secretaria da } \\
\text { Agricultura e do Abastecimento } \\
\text { do Estado do Paraná, } \\
\text { Departamento de Economia Rural } \\
\text { (Seab-PR) - ERAL12_ } \\
\text { PRBGO12 }\end{array}$ & $\begin{array}{l}\text { Reales nomi- } \\
\operatorname{nal}(\mathrm{R} \$)\end{array}$ & $\begin{array}{l}\text { Monthly fed cattle producer } \\
\text { price, } \mathrm{R} \$ / 15 \mathrm{~kg} \text {, live farm de- } \\
\text { livery, Parana State, up to } 16 \\
\text { arrobas. Prices are divided by } \\
15 \text { (arroba }=15 \mathrm{~kg} \text { ) }\end{array}$ & $\begin{array}{l}\text { Reales }(\mathrm{R} \$) \\
\text { real prices }\end{array}$ & $\begin{array}{l}\text { IPEA. Institute for Applied Eco- } \\
\text { nomic Research with data of the } \\
\text { Agriculture and Supply Service } \\
\text { of Parana State (Seab) }\end{array}$ \\
\hline & Chile & $\begin{array}{l}\text { Precios a productor de Novillo } \\
\text { s/e, \$/kilo (Pesos nominales sin } \\
\text { IVA) }\end{array}$ & $\begin{array}{l}\text { Chilean pesos } \\
(\mathrm{Ch} \$), \text { nomi- } \\
\text { nal prices }\end{array}$ & $\begin{array}{l}\text { Monthly producer price, } \$ / \mathrm{kg} \text {, } \\
\text { live, Tattersal Santiago live- } \\
\text { stock auction prices }\end{array}$ & $\begin{array}{l}\text { Chilean pesos } \\
(\mathrm{Ch} \$), \text { real } \\
\text { prices }\end{array}$ & $\begin{array}{l}\text { ODEPA. Agriculture policy and } \\
\text { research bureau (Oficina de } \\
\text { Estudios y Políticas Agrarias) }\end{array}$ \\
\hline & Uruguay & Novillo Gordo USD/kg en pie & Dollar (USD) & $\begin{array}{l}\text { Monthly live fed cattle, } \\
\text { US } \$ / \mathrm{kg} \text {, up to } 380 \mathrm{~kg} \text {, slaugh- } \\
\text { terhouse delivered. }\end{array}$ & $\begin{array}{l}\text { Uruguayan } \\
\text { pesos (Ur\$), } \\
\text { real prices }\end{array}$ & $\begin{array}{l}\text { INAC. National meat institute } \\
\text { (Instituto Nacional de la carne) }\end{array}$ \\
\hline
\end{tabular}




\begin{tabular}{|c|c|c|c|c|c|c|}
\hline & Country & Element & $\begin{array}{l}\text { Original cur- } \\
\text { rency }\end{array}$ & Description & $\begin{array}{l}\text { Transformed } \\
\text { currency } \\
\text { (CPI, base } \\
\text { year 2000/1) }\end{array}$ & Data source \\
\hline \multirow[t]{3}{*}{$\begin{array}{l}\text { Consu- } \\
\text { mer Price } \\
\text { index }\end{array}$} & Brazil & $\begin{array}{l}\text { IPC - geral - índice (jun. } 1994= \\
\text { 100) - RMSP }\end{array}$ & $\begin{array}{l}\text { Base year } \\
1994 / 6\end{array}$ & $\begin{array}{l}\text { Monthly general CPI, calcula- } \\
\text { tion of the Fundação Getulio } \\
\text { Vargas (RJ), RMSP: metro- } \\
\text { politan region of Sao Paulo } \\
\text { (RMSP) }\end{array}$ & $\begin{array}{l}\text { Base year } \\
2001 / 1\end{array}$ & $\begin{array}{l}\text { IPEA. Applied economy re- } \\
\text { search institute with data of } \\
\text { FIPE (Fundação Instituto de } \\
\text { Pesquisas Econômicas) }\end{array}$ \\
\hline & Chile & $\begin{array}{l}\text { Cifras de indicadores } \\
\text { económicos, Series Combinadas, } \\
\text { IPC general base dic/2008, IPC } \\
\text { general base } 2013\end{array}$ & $\begin{array}{l}\text { Combination } \\
\text { of two CPI se- } \\
\text { ries: base year } \\
2008 / 12 \text { and } \\
2013\end{array}$ & Monthly CPI. & $\begin{array}{l}\text { Base year } \\
2001 / 1\end{array}$ & $\begin{array}{l}\text { ODEPA. Agriculture policy and } \\
\text { research bureau } \\
\text { (Oficina de Estudios y Políticas } \\
\text { Agrarias) }\end{array}$ \\
\hline & Uruguay & $\begin{array}{l}\text { Índice de Precios del Consumo, } \\
\text { Total País, Nivel General, Base } \\
\text { Diciembre } 2010=100 \text {, Período: } \\
\text { 1937- }\end{array}$ & $\begin{array}{l}\text { Base year } \\
2010\end{array}$ & $\begin{array}{l}\text { Monthly general CPI, base } \\
\text { year } 2010 .\end{array}$ & $\begin{array}{l}\text { Base year } \\
2001 / 1\end{array}$ & $\begin{array}{l}\text { INE. National Institute of } \\
\text { Statistic Instituto Nacional de } \\
\text { Estadística }\end{array}$ \\
\hline Dollar & Uruguay & $\begin{array}{l}\text { Cotización Interbancario Dólar } \\
\text { Billete, Período: Diciembre 1968- } \\
\text {, vendedor }\end{array}$ & & Monthly dollar value, seller. & & $\begin{array}{l}\text { INE. National institute of statis- } \\
\text { tic (Instituto Nacional de Es- } \\
\text { tadística) with data of the Banco } \\
\text { Central del Uruguay (BCU). }\end{array}$ \\
\hline
\end{tabular}

Source: Authors. 
Table A. 6 Descriptive statistics of analyzed producer prices for pig and cattle by country

\begin{tabular}{|c|c|c|c|c|c|c|}
\hline & \multicolumn{3}{|c|}{ Pig producer prices } & \multicolumn{3}{|c|}{ Cattle producer prices } \\
\hline & Brazil & Chile & Uruguay & Brazil & Chile & Uruguay \\
\hline Start month & 01.1990 & 01.1976 & 01.1984 & 01.1990 & 01.1976 & 01.1984 \\
\hline Last month & 12.2016 & 12.2016 & 12.2008 & 12.2016 & 12.2016 & 12.2016 \\
\hline $\begin{array}{l}\text { Number of } \\
\text { obs. }\end{array}$ & 324 & 492 & 300 & 324 & 492 & 396 \\
\hline Unit & $\mathrm{R} \$ / \mathrm{kg}$ & $\mathrm{Ch} \$ / \mathrm{kg}$ & $\mathrm{Ur} \$ / \mathrm{kg}$ & $\mathrm{R} \$ / \mathrm{kg}$ & $\mathrm{Ch} \$ / \mathrm{kg}$ & $\mathrm{Ur} \$ / \mathrm{kg}$ \\
\hline Mean & 1.0 & 556 & 15 & 3 & 611 & 13 \\
\hline Median & 0.9 & 451 & 12 & 3 & 604 & 13 \\
\hline Std. dev. & 0.2 & 164 & 6 & 1 & 125 & 3 \\
\hline Min. & 0.5 & 197 & 8 & 2 & 321 & 7 \\
\hline Max. & 1.8 & 1007 & 31 & 4 & 969 & 22 \\
\hline $\mathrm{CV}$ & 0.3 & 0.3 & 0.4 & 0.2 & 0.2 & 0.2 \\
\hline
\end{tabular}

Source: Authors.

As the data are in national currencies, real prices have differing units and are hardly comparable. Thus, Figures A.4 and A.5 plot the annual minima and maxima of the indexed pig and cattle prices, respectively. The indexed prices, calculated with the equation A.1, represent the percentage deviation of each real price in the respective national currency (deflated, with basis 2001/01) for each month relative to its respective mean, which is calculated as follows:

$$
\text { price index }=\frac{\text { real price }}{\text { mean }}-1
$$

This approach has the advantage that the magnitudes of the price cycles are measured in relative terms to the mean of each series.

Therefore, Figures A.4 and A.5 provide insight into annual relative price movements by neglecting the seasonal intra-year variations. The minima (maxima) lines for pig and cattle show a cyclic pattern; the indexed pig prices present a peak (trough) roughly every 2 to 4 years, and the indexed cattle price approximately every 6 to 8 years. The gap between the minima and maxima of the pig prices shown in Figure A.4 for Brazil and Chile stay constant, while Uruguay's gets smaller towards the end. Comparing the three indexed prices at the beginning of the 90s, all indexed prices act similarly; but starting in 1998, Brazil's index disjoins from Uruguay's and Chile's. Brazil's minima move to resemble the maxima of Chile's and Uruguay's indexed prices. After 2002, Brazil's indexed pig prices undergo drastic changes so that in 2006 and 2009 the maxima are lower than the minima in the previous year. 


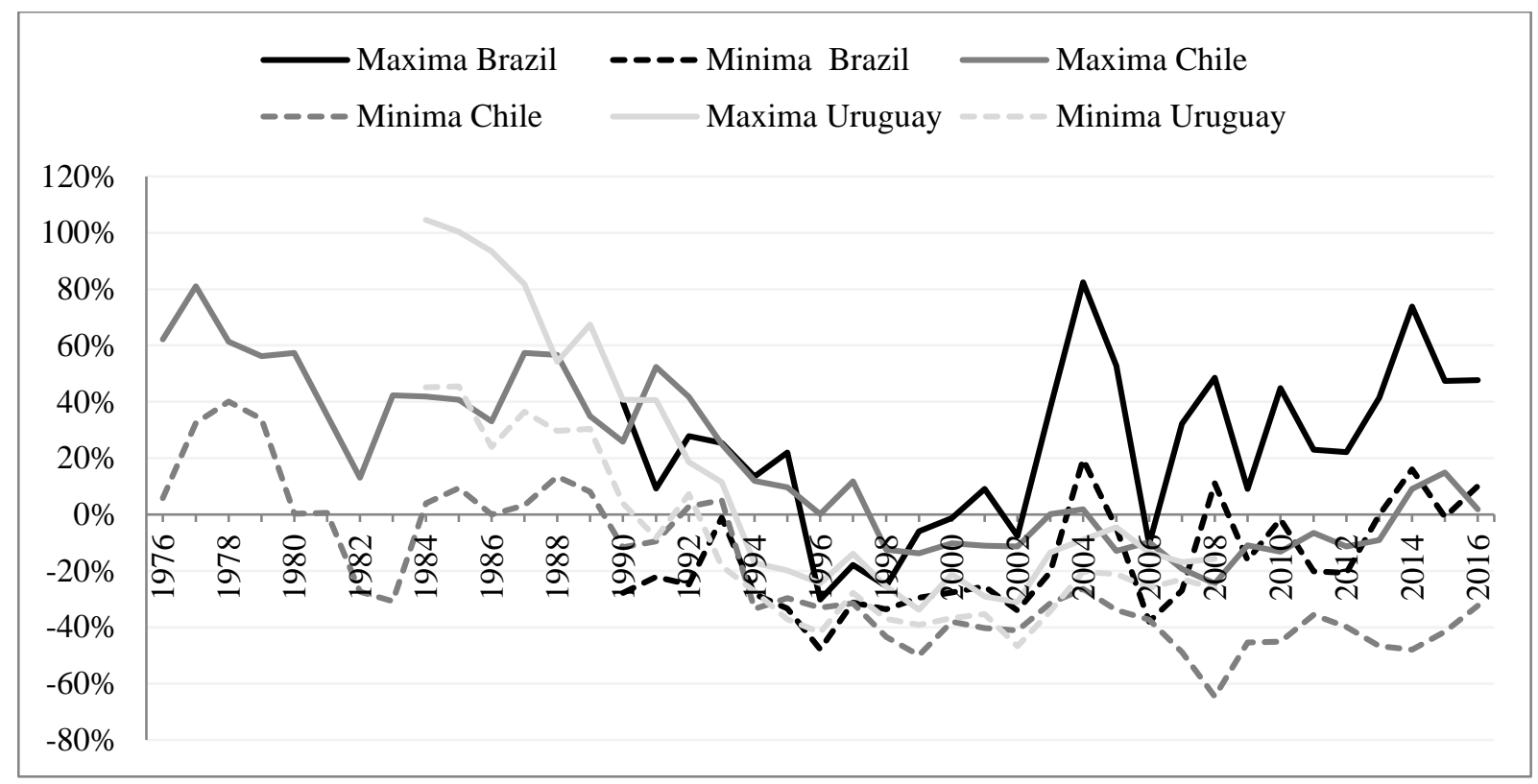

Figure A. 4 Annual minima and maxima of indexed pig price by country, 1976-2016

Source: Authors.

The gap between the indexed cattle prices in Figure A.5 remains constant for Chile and Uruguay, but in the case of Brazil, it decreases over time. This results in Brazil's minima to be above the indexed prices of Chile and Uruguay. Starting in 1998, Brazil's, Chile's and Uruguay's indexed prices behave similarly; they display peaks in the same years. At the end of the price series, the peaks appear quite often, reducing the cycle length to approximately 4 years.

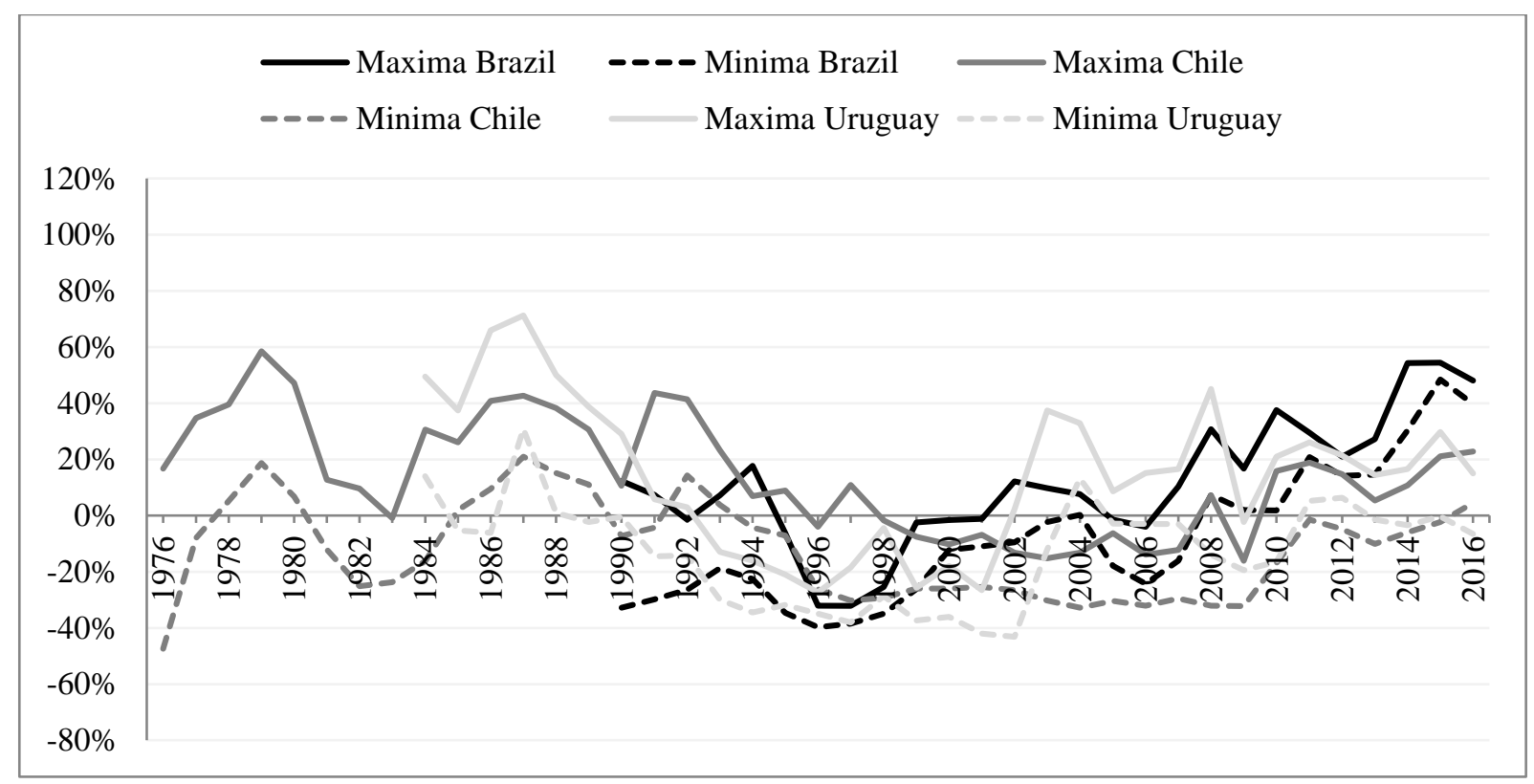

Figure A. 5 Annual minima and maxima of indexed cattle prices by country, 1976-2016

Source: Authors. 
Table A. 7 Calculated models with the corresponding selection criteria

\begin{tabular}{|c|c|c|c|c|c|}
\hline \multirow{2}{*}{$\begin{array}{l}\text { Model } \\
\text { Country }\end{array}$} & \multicolumn{4}{|c|}{ Residual testing } & \multirow{2}{*}{$\frac{\text { Selection criteria }}{\text { AIC }}$} \\
\hline & Product & Normality & $\begin{array}{l}\text { Homosceda- } \\
\text { sticity }\end{array}$ & $\begin{array}{c}\text { No autocorre- } \\
\text { lation }\end{array}$ & \\
\hline Brazil M1 & Pork & no & no & no & -4.18 \\
\hline Brazil M2 & Pork & no & no & no & -4.13 \\
\hline Brazil M3 & Pork & no & yes & no & -2.99 \\
\hline Chile M1 & Pork & yes & no & no & 7.81 \\
\hline Chile M2 & Pork & yes & yes & no & 8.04 \\
\hline Chile M3 & Pork & yes & yes & no & 8.01 \\
\hline Uruguay M1 & Pork & no & yes & no & 0.45 \\
\hline Uruguay M2 & Pork & no & yes & no & 0.39 \\
\hline Uruguay M3 & Pork & no & yes & no & 1.75 \\
\hline Brazil M1 & Cattle & no & yes & no & -3.23 \\
\hline Brazil M2 & Cattle & no & yes & no & -3.44 \\
\hline Brazil M3 & Cattle & yes & yes & no & -2.21 \\
\hline Chile M1 & Cattle & yes & yes & no & 7.31 \\
\hline Chile M2 & Cattle & yes & yes & no & 6.96 \\
\hline Chile M3 & Cattle & no & yes & no & 7.16 \\
\hline Uruguay M1 & Cattle & no & yes & no & 0.23 \\
\hline Uruguay M2 & Cattle & no & yes & no & 0.21 \\
\hline Uruguay M3 & Cattle & no & yes & no & 0.98 \\
\hline
\end{tabular}

Source: Authors.

The six selected models in Table A.7 are in bolt. The selected Chilean cattle model shows the optimal selection criteria: good residual characteristics (normality and homoscedasticity) and the smallest selection criteria of the other two models. We first choose the model with the efficient/ best residual characteristics and then look for the smallest model selection criteria. In some cases the chosen model has the efficient/best residual characteristics and the second or third smallest model selection criteria. 
Table A. 8 Structural breaks and outliers

\begin{tabular}{|c|c|c|c|c|c|}
\hline Country & Structural breaks & Coefficient & $\begin{array}{c}\text { Root Mean } \\
\text { Square } \\
\text { Error } \\
(\text { RMSE })^{21}\end{array}$ & t-value & P-value \\
\hline Brazil pig & No structural breaks & & & & \\
\hline Chile pig & $\begin{array}{l}\text { Level break 1977(11) } \\
\text { Level break 1976(8) } \\
\text { Level break 1983(2) } \\
\text { Level break 1994(1) } \\
\text { Level break 2014(9) } \\
\text { Level break 1982(1) } \\
\text { Level break 1991(10) } \\
\text { Level break 2002(12) } \\
\text { Level break 1987(7) } \\
\text { Level break 2009(9) } \\
\text { Level break 1980(10) } \\
\text { Level break 1991(4) }\end{array}$ & $\begin{array}{r}-55.95 \\
255.43 \\
192.04 \\
-124.73 \\
136.64 \\
-104.86 \\
-72.48 \\
97.60 \\
76.08 \\
84.51 \\
-130.13 \\
112.44\end{array}$ & $\begin{array}{l}19.43 \\
30.11 \\
18.94 \\
16.17 \\
15.44 \\
22.47 \\
26.32 \\
15.91 \\
14.23 \\
14.38 \\
19.16 \\
25.51\end{array}$ & $\begin{array}{r}-2.88 \\
8.48 \\
10.14 \\
-7.72 \\
8.85 \\
-4.67 \\
-2.75 \\
6.14 \\
5.35 \\
5.88 \\
-6.79 \\
4.41\end{array}$ & $\begin{array}{r}0.004 \\
<0.001 \\
<0.001 \\
<0.001 \\
<0.001 \\
<0.001 \\
0.006 \\
<0.001 \\
<0.001 \\
<0.001 \\
<0.001 \\
<0.001\end{array}$ \\
\hline Uruguay pig & $\begin{array}{l}\text { Level break 1993(3) } \\
\text { Level break 1990(1) } \\
\text { Level break 1992(9) } \\
\text { Level break 1995(9) } \\
\text { Slope break 1991(3) }\end{array}$ & $\begin{array}{r}-3.28 \\
-2.36 \\
-1.62 \\
-2.93 \\
0.09\end{array}$ & $\begin{array}{l}0.82 \\
0.74 \\
0.82 \\
0.58 \\
0.01\end{array}$ & $\begin{array}{r}-4.02 \\
-3.21 \\
-1.99 \\
-5.05 \\
6.46\end{array}$ & $\begin{array}{r}<0.001 \\
0.001 \\
0.047 \\
<0.001 \\
<0.001\end{array}$ \\
\hline Brazil cattle & Level break 1996(9) & -0.59 & 0.08 & -7.85 & $<0.001$ \\
\hline Chile cattle & $\begin{array}{l}\text { Level break 1976(7) } \\
\text { Level break 1977(7) } \\
\text { Level break 1978(7) } \\
\text { Level break 1980(10) } \\
\text { Level break 1981(12) } \\
\text { Level break 1989(11) } \\
\text { Level break 1994(1) } \\
\text { Level break 1976(8) } \\
\text { Level break 1977(11) } \\
\text { Level break 1979(7) } \\
\text { Level break 1983(7) } \\
\text { Level break 1984(7) } \\
\text { Level break 1986(6) } \\
\text { Level break 1991(6) } \\
\text { Level break 1995(12) } \\
\text { Level break 2010(1) } \\
\text { Slope break 2005(1) }\end{array}$ & $\begin{array}{r}156.80 \\
126.78 \\
109.50 \\
-181.33 \\
-126.23 \\
-114.33 \\
-121.64 \\
121.21 \\
-80.36 \\
80.70 \\
61.80 \\
124.22 \\
123.65 \\
129.46 \\
-66.57 \\
87.59 \\
1.58\end{array}$ & $\begin{array}{r}36.23 \\
28.42 \\
24.32 \\
19.43 \\
18.38 \\
14.62 \\
14.39 \\
35.20 \\
29.73 \\
20.33 \\
19.30 \\
18.63 \\
13.80 \\
15.21 \\
14.61 \\
16.25 \\
0.25\end{array}$ & $\begin{array}{r}4.33 \\
4.46 \\
4.50 \\
-9.33 \\
-6.87 \\
-7.82 \\
-8.45 \\
3.44 \\
-2.70 \\
3.97 \\
3.20 \\
6.67 \\
8.96 \\
8.51 \\
-4.56 \\
5.39 \\
6.46\end{array}$ & $\begin{array}{r}<0.001 \\
<0.001 \\
<0.001 \\
<0.001 \\
<0.001 \\
<0.001 \\
<0.001 \\
0.001 \\
0.007 \\
<0.001 \\
0.002 \\
<0.001 \\
<0.001 \\
<0.001 \\
<0.001 \\
<0.001 \\
<0.001\end{array}$ \\
\hline Uruguay cattle & $\begin{array}{l}\text { Level break 2002(7) } \\
\text { Level break 2003(3) } \\
\text { Level break 1992(4) }\end{array}$ & $\begin{array}{r}3.71 \\
2.20 \\
-4.62\end{array}$ & $\begin{array}{l}0.71 \\
0.71 \\
0.43\end{array}$ & $\begin{array}{r}5.25 \\
3.09 \\
-10.66\end{array}$ & $\begin{array}{r}<0.001 \\
0.002 \\
<0.001\end{array}$ \\
\hline
\end{tabular}

Source: Authors.

\footnotetext{
${ }^{21}$ Measure of the differences between values predicted by a model or an estimator and the values actually observed.
} 
Table A. 9 Literature review of papers analyzing synchronization

\begin{tabular}{|c|c|c|c|c|c|}
\hline Paper & Methodology & Context & Country & $\begin{array}{c}\text { Time } \\
\text { period }\end{array}$ & $\begin{array}{c}\text { Synchronization } \\
\text { confirmed }\end{array}$ \\
\hline Afef (2014) & $\begin{array}{l}\text { Uni and multivariate } \\
\text { unobserved compo- } \\
\text { nents, structural time } \\
\text { series models }\end{array}$ & $\begin{array}{l}\text { Stock mar- } \\
\text { ket cycles, } \\
\text { business } \\
\text { cycle }\end{array}$ & $\begin{array}{l}\text { Argentina, Brazil, } \\
\text { Chile, Colombia, } \\
\text { Mexico, } \\
\text { Philippines, Korea, } \\
\text { Taiwan, Thailand, } \\
\text { USA }\end{array}$ & $\begin{array}{c}1975- \\
2005\end{array}$ & yes \\
\hline $\begin{array}{l}\text { Aiolfi, Catão, } \\
\text { and } \\
\text { Timmermann } \\
(2011)\end{array}$ & $\begin{array}{l}\text { Concordance index of } \\
\text { Harding and Pagan } \\
(2002)\end{array}$ & $\begin{array}{l}\text { Business } \\
\text { cycle }\end{array}$ & $\begin{array}{l}\text { Argentina, Brazil, } \\
\text { Chile, Mexico }\end{array}$ & $\begin{array}{c}1870- \\
2004\end{array}$ & yes \\
\hline $\begin{array}{l}\text { Akimov, } \\
\text { Stevenson and } \\
\text { Young (2015) }\end{array}$ & $\begin{array}{l}\text { Two alternative de- } \\
\text { composition ap- } \\
\text { proaches: Beveridge } \\
\text { and Nelson (1981) } \\
\text { and Hodrick-Prescott } \\
\text { (1997), concordance } \\
\text { index by Harding and } \\
\text { Pagan (2006) }\end{array}$ & Housing & Australia & $\begin{array}{l}1986- \\
2010\end{array}$ & yes \\
\hline $\begin{array}{l}\text { Arkolakis and } \\
\text { Ramanarayana } \\
\text { n (2009) }\end{array}$ & $\begin{array}{l}\text { Cross-country corre- } \\
\text { lation of Hodrick- } \\
\text { Prescott -filtered vari- } \\
\text { ables }\end{array}$ & $\begin{array}{l}\text { Business } \\
\text { cycle }\end{array}$ & $\begin{array}{l}\text { Canada, France, } \\
\text { Germany, Japan, } \\
\text { UK, USA }\end{array}$ & $\begin{array}{l}1971- \\
1990\end{array}$ & yes \\
\hline $\begin{array}{l}\text { Artis and } \\
\text { Zhang (1997) }\end{array}$ & $\begin{array}{l}\text { Hodrick-Prescott fil- } \\
\text { ter and correlation }\end{array}$ & $\begin{array}{l}\text { Industrial } \\
\text { production }\end{array}$ & $\begin{array}{l}\text { Belgium, Canada, } \\
\text { Finland, France, } \\
\text { Germany, Ireland, } \\
\text { Italy, Japan, } \\
\text { Netherlands, Nor- } \\
\text { way, Portugal, } \\
\text { Spain, Sweden, } \\
\text { UK, USA }\end{array}$ & $\begin{array}{c}1961- \\
1993\end{array}$ & yes \\
\hline $\begin{array}{l}\text { Calderón } \\
(2007)\end{array}$ & $\begin{array}{l}\text { Correlation. Band- } \\
\text { Pass filter (Baxter } \\
\text { and King (1999) } \\
\end{array}$ & $\begin{array}{l}\text { Business } \\
\text { cycle }\end{array}$ & $\begin{array}{l}\text { Latin America, } \\
\text { China and India }\end{array}$ & $\begin{array}{l}1965- \\
2004\end{array}$ & yes \\
\hline $\begin{array}{l}\text { Calderón et al. } \\
\text { (2007) }\end{array}$ & $\begin{array}{l}\text { Panel regression } \\
\text { equation and correla- } \\
\text { tion between cyclical } \\
\text { outputs }\end{array}$ & $\begin{array}{l}\text { Business } \\
\text { cycle }\end{array}$ & $\begin{array}{l}\text { Industrial countries } \\
\text { and developing } \\
\text { countries }\end{array}$ & $\begin{array}{c}1960- \\
1999\end{array}$ & yes \\
\hline $\begin{array}{l}\text { Camacho and } \\
\text { Perez-Quiros } \\
(2006)\end{array}$ & $\begin{array}{l}\text { Multivariate Markov- } \\
\text { switching approach }\end{array}$ & $\begin{array}{l}\text { Business } \\
\text { cycle }\end{array}$ & $\begin{array}{l}\text { Canada, France, } \\
\text { Germany, Italy, Ja- } \\
\text { pan, UK, USA (G7) }\end{array}$ & $\begin{array}{c}1980- \\
2004\end{array}$ & yes \\
\hline $\begin{array}{l}\text { Camacho, } \\
\text { Perez-Quiros, } \\
\text { and Saiz } \\
(2006)\end{array}$ & $\begin{array}{l}\text { VAR-based approach } \\
\text { den Haan (2000), } \\
\text { spectral analysis, fol- } \\
\text { lowing Croux et al. } \\
\text { (2001). Business } \\
\text { cycle dummy variab- } \\
\text { les, following Har- } \\
\text { ding and Pagan } \\
(2002)\end{array}$ & $\begin{array}{l}\text { Business } \\
\text { cycle }\end{array}$ & $\begin{array}{l}\text { Austria, Belgium, } \\
\text { Germany, Greece, } \\
\text { Finland, France, } \\
\text { Italy, Ireland, Lu- } \\
\text { xembourg, Nether- } \\
\text { lands, Portugal, } \\
\text { Spain (EU12) }\end{array}$ & $\begin{array}{l}1962- \\
2003\end{array}$ & yes \\
\hline
\end{tabular}




\begin{tabular}{|c|c|c|c|c|c|}
\hline Paper & Methodology & Context & Country & $\begin{array}{c}\text { Time } \\
\text { period }\end{array}$ & $\begin{array}{c}\text { Synchronization } \\
\text { confirmed }\end{array}$ \\
\hline $\begin{array}{l}\text { Candelon, } \\
\text { Piplack and } \\
\text { Straetmans } \\
(2008)\end{array}$ & $\begin{array}{l}\text { Generalized method } \\
\text { of moments, extends } \\
\text { Harding and Pagan } \\
\text { (2006) for testing } \\
\text { strong multivariate } \\
\text { non-synchronization } \\
\text { (SMNS) test for en- } \\
\text { dogenously determin- } \\
\text { ing structural change } \\
\text { in synchronization }\end{array}$ & $\begin{array}{l}\text { Stock mar- } \\
\text { kets }\end{array}$ & $\begin{array}{l}\text { South Korea, Ma- } \\
\text { laysia, Singapore, } \\
\text { Taiwan, Thailand }\end{array}$ & $\begin{array}{l}1985- \\
2005\end{array}$ & yes \\
\hline $\begin{array}{l}\text { Carvalho and } \\
\text { Harvey (2005) }\end{array}$ & $\begin{array}{l}\text { Multivariate struc- } \\
\text { tural time series } \\
\text { model }\end{array}$ & $\begin{array}{l}\text { Real per } \\
\text { capita in- } \\
\text { comes }\end{array}$ & $\begin{array}{l}\text { Austria, Belgium, } \\
\text { Finland, France, } \\
\text { Germany, Greece, } \\
\text { Ireland, Italy, } \\
\text { Netherland, Portu- } \\
\text { gal, Spain (EU11) }\end{array}$ & $\begin{array}{c}1950- \\
1997\end{array}$ & yes \\
\hline $\begin{array}{l}\text { Cerqueira and } \\
\text { Martins } \\
(2009)\end{array}$ & $\begin{array}{l}\text { Synchronization in- } \\
\text { dex. This index dis- } \\
\text { tinguishes negative } \\
\text { correlations due to } \\
\text { episodes in single } \\
\text { years, asynchronous } \\
\text { behavior in turbulent } \\
\text { times and synchro- } \\
\text { nous behavior over } \\
\text { stable periods }\end{array}$ & GDP & $\begin{array}{l}\text { OECD } 20 \text { (Austra- } \\
\text { lia, Austria, Ca- } \\
\text { nada, Denmark, } \\
\text { Finland, France, } \\
\text { Germany, Greece, } \\
\text { Iceland, Ireland, } \\
\text { Italy, Japan, } \\
\text { Netherlands, Nor- } \\
\text { way, Portugal, } \\
\text { Spain, Sweden, } \\
\text { Switzerland, UK } \\
\text { and USA) }\end{array}$ & $\begin{array}{l}1970- \\
2002\end{array}$ & no \\
\hline $\begin{array}{l}\text { Darvas and } \\
\text { Szapáry } \\
(2008)\end{array}$ & $\begin{array}{l}\text { Band-Pass filter (BP), } \\
\text { State space models. } \\
\text { Correlation, Persis- } \\
\text { tence, impulse-re- } \\
\text { sponse (VAR) }\end{array}$ & GDP & $\begin{array}{l}\text { EECs, EU, EU- } \\
\text { outs, Norway, Rus- } \\
\text { sia, Switzerland, } \\
\text { USA }\end{array}$ & $\begin{array}{l}1983- \\
2002\end{array}$ & yes \\
\hline $\begin{array}{l}\text { Delajara } \\
(2012)\end{array}$ & $\begin{array}{l}\text { SUTSE (Harvey, } \\
\text { 1989; Harvey and } \\
\text { Koopman 1997; Dur- } \\
\text { bin and Koopman, } \\
\text { 2001; Carvalho and } \\
\text { Harvey, 2005) Con- } \\
\text { cordance index }\end{array}$ & $\begin{array}{l}\text { Business } \\
\text { cycle }\end{array}$ & Mexico, USA & $\begin{array}{l}2003- \\
2010\end{array}$ & yes \\
\hline $\begin{array}{l}\text { Duarte and } \\
\text { Holden (2003) }\end{array}$ & $\begin{array}{l}\text { Hodrick-Prescott fil- } \\
\text { ter (1997), Correla- } \\
\text { tions, autoregressive- } \\
\text { distributed lag mod- } \\
\text { els, error-correction } \\
\text { models }\end{array}$ & $\begin{array}{l}\text { Business } \\
\text { cycle }\end{array}$ & $\begin{array}{l}\text { Canada, France, } \\
\text { Germany, Italy, Ja- } \\
\text { pan, UK, USA }\end{array}$ & $\begin{array}{c}1960- \\
1997\end{array}$ & yes \\
\hline Duran (2011) & $\begin{array}{l}\text { Hodrick-Prescott } \\
\text { (1997); Christiano } \\
\text { and Fitzgerald (2003) } \\
\text { filter. Concordance } \\
\text { index and the diffu- } \\
\text { sion index, cross- } \\
\text { sectional variance }\end{array}$ & $\begin{array}{l}\text { Business } \\
\text { cycle }\end{array}$ & USA & $\begin{array}{l}1969- \\
2008\end{array}$ & yes, decreasing \\
\hline
\end{tabular}




\begin{tabular}{|c|c|c|c|c|c|}
\hline Paper & Methodology & Context & Country & $\begin{array}{c}\text { Time } \\
\text { period }\end{array}$ & $\begin{array}{c}\text { Synchronization } \\
\text { confirmed }\end{array}$ \\
\hline $\begin{array}{l}\text { Eickmeier and } \\
\text { Breitung } \\
(2006)\end{array}$ & $\begin{array}{l}\text { Dynamic correlations } \\
\text { and multivariate co- } \\
\text { hesion (Croux et al., } \\
\text { 2001). Structural dy- } \\
\text { namic factor model } \\
\text { (Forni and Reichlin, } \\
\text { 1998; Giannone et al., } \\
\text { 2002) }\end{array}$ & $\begin{array}{l}\text { Business } \\
\text { cycle }\end{array}$ & $\begin{array}{l}\text { Old EU and new } \\
\text { EU members } \\
\text { (Czech Republic, } \\
\text { Estonia, Hungary, } \\
\text { Lithuania, Latvia, } \\
\text { Poland, Slovenia, } \\
\text { Slovakia with Malta } \\
\text { and Cyprus) }\end{array}$ & $\begin{array}{l}1993- \\
2003\end{array}$ & yes \\
\hline Fiess (2007) & $\begin{array}{l}\text { Correlation, Frankel } \\
\text { and Rose's (1998) ap- } \\
\text { proach }\end{array}$ & $\begin{array}{l}\text { Business } \\
\text { cycle }\end{array}$ & $\begin{array}{l}\text { Argentina, Brazil, } \\
\text { Canada, Costa Rica, } \\
\text { El Salvador, } \\
\text { France, Germany, } \\
\text { Guatemala, } \\
\text { Honduras, Mexico, } \\
\text { Nicaragua, Panama, } \\
\text { Portugal, Spain, } \\
\text { USA, France, } \\
\text { Germany, Portugal, } \\
\text { Spain, UK }\end{array}$ & $\begin{array}{l}1965- \\
2002\end{array}$ & yes \\
\hline $\begin{array}{l}\text { Fisher and } \\
\text { Konieczny } \\
(2000)\end{array}$ & $\begin{array}{l}\text { Fisher-Konieczny in- } \\
\text { dex, } X^{2} \text { goodness-of- } \\
\text { fit test }\end{array}$ & $\begin{array}{l}\text { Canadian } \\
\text { newspaper } \\
\text { prices }\end{array}$ & Canada & $\begin{array}{c}1975- \\
1990\end{array}$ & yes \\
\hline $\begin{array}{l}\text { Gaechter, } \\
\text { Riedl and } \\
\text { Ritzberger- } \\
\text { Gruenwald } \\
\text { (2012) } \\
\end{array}$ & $\begin{array}{l}\text { Hodrick-Prescott fil- } \\
\text { ter. Correlation coef- } \\
\text { ficients and standard } \\
\text { deviation of the cycli- } \\
\text { cal component }\end{array}$ & $\begin{array}{l}\text { Business } \\
\text { cycle }\end{array}$ & $\mathrm{EU}$ & $\begin{array}{l}1995- \\
2012\end{array}$ & $\begin{array}{l}\text { decreasing synchro- } \\
\text { nization of business } \\
\text { cycles during the } \\
\text { crisis period }\end{array}$ \\
\hline $\begin{array}{l}\text { Geise and } \\
\text { Pilatowska } \\
(2013)\end{array}$ & $\begin{array}{l}\text { Markov-switching } \\
\text { autoregressive model } \\
\text { and correlation coef- } \\
\text { ficients }\end{array}$ & $\begin{array}{l}\text { Oil price } \\
\text { cycle and } \\
\text { business } \\
\text { cycle }\end{array}$ & Poland & $\begin{array}{l}1995- \\
2013\end{array}$ & yes \\
\hline $\begin{array}{l}\text { Gonçalves, } \\
\text { Rodrigues and } \\
\text { Soares (2009) }\end{array}$ & $\begin{array}{l}\text { Hodrick-Prescott fil- } \\
\text { ter (1997) and corre- } \\
\text { lation }\end{array}$ & $\begin{array}{l}\text { Business } \\
\text { cycle }\end{array}$ & $\begin{array}{l}\text { EU and some } \\
\text { OECD countries } \\
\text { (Austria, Australia, } \\
\text { Belgium, Canada, } \\
\text { Denmark, Finland, } \\
\text { France, Germany, } \\
\text { Greece, Iceland, } \\
\text { Ireland, Italy, Ja- } \\
\text { pan, Luxembourg, } \\
\text { Netherlands, New } \\
\text { Zealand, Norway, } \\
\text { Portugal, Spain, } \\
\text { Sweden, Switzer- } \\
\text { land, UK, USA) }\end{array}$ & $\begin{array}{l}1980- \\
2007\end{array}$ & yes \\
\hline $\begin{array}{l}\text { Harding and } \\
\text { Pagan (2006) }\end{array}$ & $\begin{array}{l}\text { Markov chains. Pear- } \\
\text { son test }\end{array}$ & $\begin{array}{l}\text { Industrial } \\
\text { production } \\
\text { //stock } \\
\text { markets }\end{array}$ & $\begin{array}{l}\text { Industrial produc- } \\
\text { tion in Belgium, } \\
\text { Canada, Finland, } \\
\text { France, Germany, } \\
\text { Ireland, Italy, Ja- } \\
\text { pan, Netherlands, } \\
\text { Norway, Portugal, } \\
\text { Spain, Sweden, } \\
\text { UK, USA // Stock } \\
\text { markets in Aus- } \\
\text { tralia, UK, USA }\end{array}$ & $\begin{array}{c}1961- \\
1993 / / \\
1875- \\
1997\end{array}$ & $\begin{array}{l}\text { Weak synchroniza- } \\
\text { tion in industrial } \\
\text { production and } \\
\text { strong synchroniza- } \\
\text { tion in stock prices. }\end{array}$ \\
\hline
\end{tabular}




\begin{tabular}{|c|c|c|c|c|c|}
\hline Paper & Methodology & Context & Country & $\begin{array}{l}\text { Time } \\
\text { period }\end{array}$ & $\begin{array}{c}\text { Synchronization } \\
\text { confirmed }\end{array}$ \\
\hline $\begin{array}{l}\text { Hirata, Kose, } \\
\text { Otrok and } \\
\text { Terrones } \\
(2012)\end{array}$ & $\begin{array}{l}\text { FAVAR (Factor Aug- } \\
\text { mented VAR) models } \\
\text { and concordance in- } \\
\text { dex by Harding and } \\
\text { Pagan (2002) }\end{array}$ & $\begin{array}{l}\text { House pri- } \\
\text { ces }\end{array}$ & $\begin{array}{l}\text { OECD (18), Aust- } \\
\text { ralia, Belgium, Ca- } \\
\text { nada, Denmark, } \\
\text { Finland, France, } \\
\text { Germany, Ireland, } \\
\text { Italy, Japan, } \\
\text { Netherlands, New } \\
\text { Zealand, Norway, } \\
\text { Spain, Sweden, } \\
\text { Switzerland, UK, } \\
\text { USA }\end{array}$ & $\begin{array}{l}1971- \\
2011\end{array}$ & yes \\
\hline $\begin{array}{l}\text { Holst and von } \\
\text { Cramon- } \\
\text { Taubadel } \\
(2012)\end{array}$ & $\begin{array}{l}\text { Hodrick-Prescott } \\
\text { (1997) filter, correla- } \\
\text { tion coefficient, } \\
\text { dummy variable with } \\
\text { regression }\end{array}$ & $\begin{array}{l}\text { Producer } \\
\text { prices for } \\
\text { slaughter } \\
\text { pigs // pro- } \\
\text { ducer } \\
\text { prices and } \\
\text { slaughter } \\
\text { volumes }\end{array}$ & $\begin{array}{l}122 \text { countries // } \\
\text { Germany, USA }\end{array}$ & $\begin{array}{c}1991- \\
2008 / / \\
1974- \\
2009\end{array}$ & $\begin{array}{l}\text { Clustered country } \\
\text { prices move to- } \\
\text { gether // no syn- } \\
\text { chronization be- } \\
\text { tween 1974-1994 } \\
\text { and synchronization } \\
\text { between 1995-2009 }\end{array}$ \\
\hline $\begin{array}{l}\text { Inklaar, Jong- } \\
\text { A-Pin and de } \\
\text { Haan (2008) }\end{array}$ & $\begin{array}{l}\text { Multivariate model. } \\
\text { Fisher's z-transfor- } \\
\text { mations of the corre- } \\
\text { lation coefficients. } \\
\text { Pairwise correlation } \\
\text { coefficient for each } \\
\text { country pair }\end{array}$ & $\begin{array}{l}\text { Business } \\
\text { cycle }\end{array}$ & OECD (21) & $\begin{array}{c}1970- \\
2003\end{array}$ & yes \\
\hline $\begin{array}{l}\text { Jaulin- } \\
\text { Mendez, } \\
\text { Bustos-Peláez, } \\
\text { Ojeda-Joya } \\
\text { and Bustos- } \\
\text { Pel (2015) } \\
\end{array}$ & $\begin{array}{l}\text { Band-Pass filter and } \\
\text { degree of synchroni- } \\
\text { zation between cycles } \\
\text { by estimating their } \\
\text { correlation coefficient }\end{array}$ & $\begin{array}{l}\text { Real com- } \\
\text { modity } \\
\text { prices and } \\
\text { world real } \\
\text { GDP }\end{array}$ & World & $\begin{array}{l}1870- \\
2010\end{array}$ & yes \\
\hline $\begin{array}{l}\text { Leiva-Leon } \\
(2014)\end{array}$ & $\begin{array}{l}\text { Markov-switching } \\
\text { framework with } \\
\text { Quadratic Probability } \\
\text { Score (QPS) crite- } \\
\text { rion. Dynamic syn- } \\
\text { chronization of busi- } \\
\text { ness cycle, bivariate, } \\
\text { multivariate and net- } \\
\text { work analyses }\end{array}$ & $\begin{array}{l}\text { Indexes of } \\
\text { real eco- } \\
\text { nomic ac- } \\
\text { tivity, }\end{array}$ & USA & $\begin{array}{l}1979- \\
2013\end{array}$ & $\begin{array}{l}\text { Decreasing syn- } \\
\text { chronization }\end{array}$ \\
\hline $\mathrm{Li}(2017)$ & $\begin{array}{l}\text { Hodrick-Prescott fil- } \\
\text { ter (1997) and Pear- } \\
\text { son correlation }\end{array}$ & Real GDP & $\begin{array}{l}\text { China, world eco- } \\
\text { nomy }\end{array}$ & $\begin{array}{l}1978- \\
2014\end{array}$ & yes \\
\hline $\begin{array}{l}\text { Michaelides } \\
\text { and } \\
\text { Papageorgiou } \\
(2012)\end{array}$ & $\begin{array}{l}\text { Hodrick-Prescott } \\
(1997) \text { Methodologi- } \\
\text { cal framework com- } \\
\text { bining conventional } \\
\text { cross correlation, } \\
\text { cointegration, } \\
\text { Granger causality, Er- } \\
\text { ror Correction Model } \\
(\mathrm{ECM}) \text { and VAR. }\end{array}$ & $\begin{array}{l}\text { Business } \\
\text { cycle }\end{array}$ & $\begin{array}{l}\text { USA and EU15 } \\
\text { (Austria, Belgium, } \\
\text { Denmark, Finland, } \\
\text { France, Germany, } \\
\text { Greece, Ireland, } \\
\text { Italy, Luxembourg, } \\
\text { Netherlands, Portu- } \\
\text { gal, Spain, Sweden, } \\
\text { UK }\end{array}$ & $\begin{array}{l}1960- \\
2011\end{array}$ & yes \\
\hline
\end{tabular}




\begin{tabular}{|c|c|c|c|c|c|}
\hline Paper & Methodology & Context & Country & $\begin{array}{c}\text { Time } \\
\text { period }\end{array}$ & $\begin{array}{c}\text { Synchronization } \\
\text { confirmed }\end{array}$ \\
\hline $\begin{array}{l}\text { Papageorgiou, } \\
\text { Michaelides } \\
\text { and Milios } \\
(2010)\end{array}$ & $\begin{array}{l}\text { Pair-wise correlation, } \\
\text { rolling window } \\
\text { approach, spectral } \\
\text { analysis and k-means } \\
\text { clustering. Hodrick- } \\
\text { Prescott filter }\end{array}$ & $\begin{array}{l}\text { Business } \\
\text { cycle }\end{array}$ & $\begin{array}{l}\text { EU (Austria, Bel- } \\
\text { gium, Denmark, } \\
\text { Finland, France, } \\
\text { Germany, Greece, } \\
\text { Ireland, Italy, Lu- } \\
\text { xembourg, Nether- } \\
\text { lands, Portugal, } \\
\text { Spain, Sweden, } \\
\text { UK), Japan, USA }\end{array}$ & $\begin{array}{c}1960- \\
2009\end{array}$ & $\begin{array}{l}\text { Decreasing syn- } \\
\text { chronization }\end{array}$ \\
\hline $\begin{array}{l}\text { Rodríguez } \\
\text { Benavides, } \\
\text { Lima Santiago } \\
\text { and Ortiz } \\
(2015)\end{array}$ & $\begin{array}{l}\text { Structural times } \\
\text { series model with a } \\
\text { stochastic } \\
\text { specification cycle }\end{array}$ & GDP & Mexico, USA & $\begin{array}{l}1960- \\
2012\end{array}$ & yes \\
\hline Rossen (2015) & $\begin{array}{l}\text { Concordance index } \\
\text { by } \\
\text { Harding and Pagan } \\
(2002)\end{array}$ & $\begin{array}{l}\text { Mineral } \\
\text { commodi- } \\
\text { ties }\end{array}$ & World prices & $\begin{array}{l}1910- \\
2011\end{array}$ & yes \\
\hline $\begin{array}{l}\text { Siedschlag } \\
(2010)\end{array}$ & $\begin{array}{l}\text { Baxter-King filter } \\
\text { (Baxter and King, } \\
\text { 1999) correlation of } \\
\text { business cycles }\end{array}$ & $\begin{array}{l}\text { Business } \\
\text { cycle (real } \\
\text { GDP) }\end{array}$ & $\begin{array}{l}\text { Austria, Belgium, } \\
\text { Finland, France, } \\
\text { Germany, Greece, } \\
\text { Italy, Netherlands, } \\
\text { Portugal, Spain, } \\
\text { Czech Republic, } \\
\text { Estonia, Hungary, } \\
\text { Lithuania, Latvia, } \\
\text { Poland, Slovenia, } \\
\text { Slovakia }\end{array}$ & $\begin{array}{l}1990- \\
2002\end{array}$ & yes \\
\hline Waelti (2005) & $\begin{array}{l}\text { Correlation coeffi- } \\
\text { cient adjusted by } \\
\text { Forbes and Rigobon } \\
\text { (2002) }\end{array}$ & $\begin{array}{l}\text { Business } \\
\text { cycle/ } \\
\text { stock re- } \\
\text { turns }\end{array}$ & $\begin{array}{l}\text { Australia, Austria, } \\
\text { Canada, Denmark, } \\
\text { France, Germany, } \\
\text { Italy, Japan, } \\
\text { Netherland, Nor- } \\
\text { way, Spain, Swe- } \\
\text { den, Switzerland, } \\
\text { USA, UK, }\end{array}$ & $\begin{array}{l}1973- \\
1997\end{array}$ & yes \\
\hline
\end{tabular}

Source: Authors. 


\section{A.4 Cases of simultaneous contraction and expansion}

In the concordance index (Harding and Pagan 2002; 2006), $S_{j t} * S_{r t}=$ measure for simultaneous expansion and $\left(1-S_{j t}\right)\left(1-S_{r t}\right)=$ measure for simultaneous contraction.

A simultaneous contraction phase in the cycles can be associated with $S_{j t} * S_{r t}=0$ when:

$S_{j t} * S_{r t}=0$ if $\left(y_{j t+1}-y_{j t}=0\right)$ and $\left(y_{r t+1}-y_{r t}=0\right) ;\left(y_{j t+1}-y_{j t}>0\right.$ and $\left(y_{r t+1}-y_{r t}=\right.$ $0) ;\left(y_{j t+1}-y_{j t}=0\right)$ and $\left(y_{r t+1}-y_{r t}>0\right)$;

A simultaneous expansion phase in the cycle can be associated with $S_{j t} * S_{r t}=1$ when:

$S_{j t} * S_{r t}=1$ if $\left(y_{j t+1}-y_{j t}>0\right)$ and $\left(y_{r t+1}-y_{r t}>0\right)$;

An expansion phase in the cycle can be associated with $\left(1-S_{j t}\right)\left(1-S_{r t}\right)=0$ when:

$\left(1-S_{j t}\right)\left(1-S_{r t}\right)=0$ if $\left(y_{j t+1}-y_{j t}=0\right)$ and $\left(y_{r t+1}-y_{r t}>0\right) ;\left(y_{j t+1}-y_{j t}>0\right)$ and

$\left(y_{r t+1}-y_{r t}=0\right) ;\left(y_{j t+1}-y_{j t}>0\right)$ and $\left(y_{r t+1}-y_{r t}>0\right)$;

A simultaneous contraction phase in the cycle can be associated with $\left(1-S_{j t}\right)\left(1-S_{r t}\right)=1$ when:

$\left(1-S_{j t}\right)\left(1-S_{r t}\right)=1$ if $\left(y_{j t+1}-y_{j t}=0\right)$ and $\left(y_{r t+1}-y_{r t}=0\right)$

\section{A.5 Cycles filtered with Kalman and Hodrick-Prescott filter}

After applying the Hodrick-Prescott filter to the calculated price index of real monthly farmgate prices of pig and cattle in Brazil, Chile and Uruguay, the obtained filtered cycles can be observed in Figure A.8 to A.9.

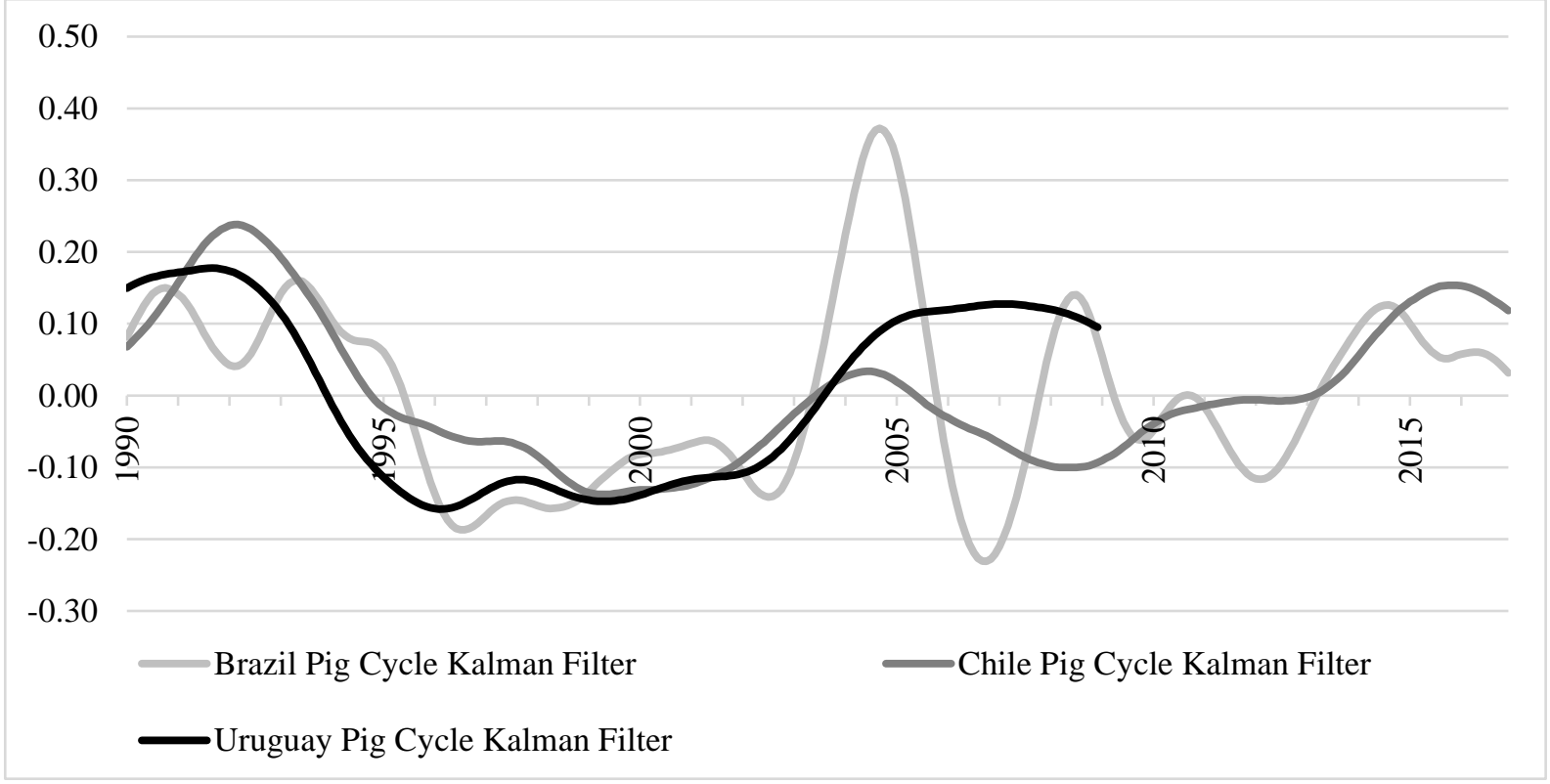

Figure A. 6 Kalman filter pig cycle in Brazil, Chile and Uruguay

Source: Authors. 


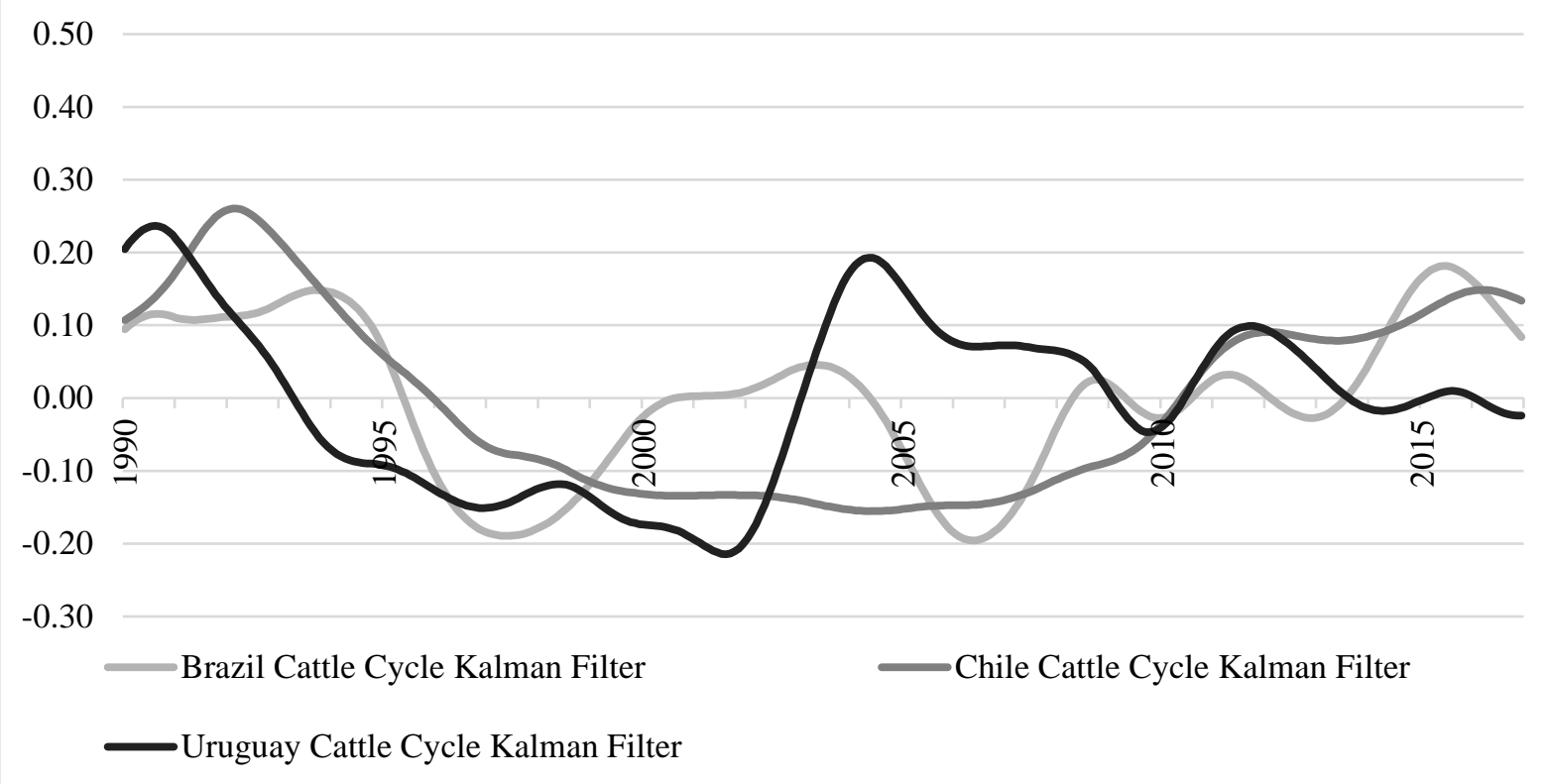

Figure A. 7 Kalman filter cattle cycle in Brazil, Chile and Uruguay

Source: Authors.

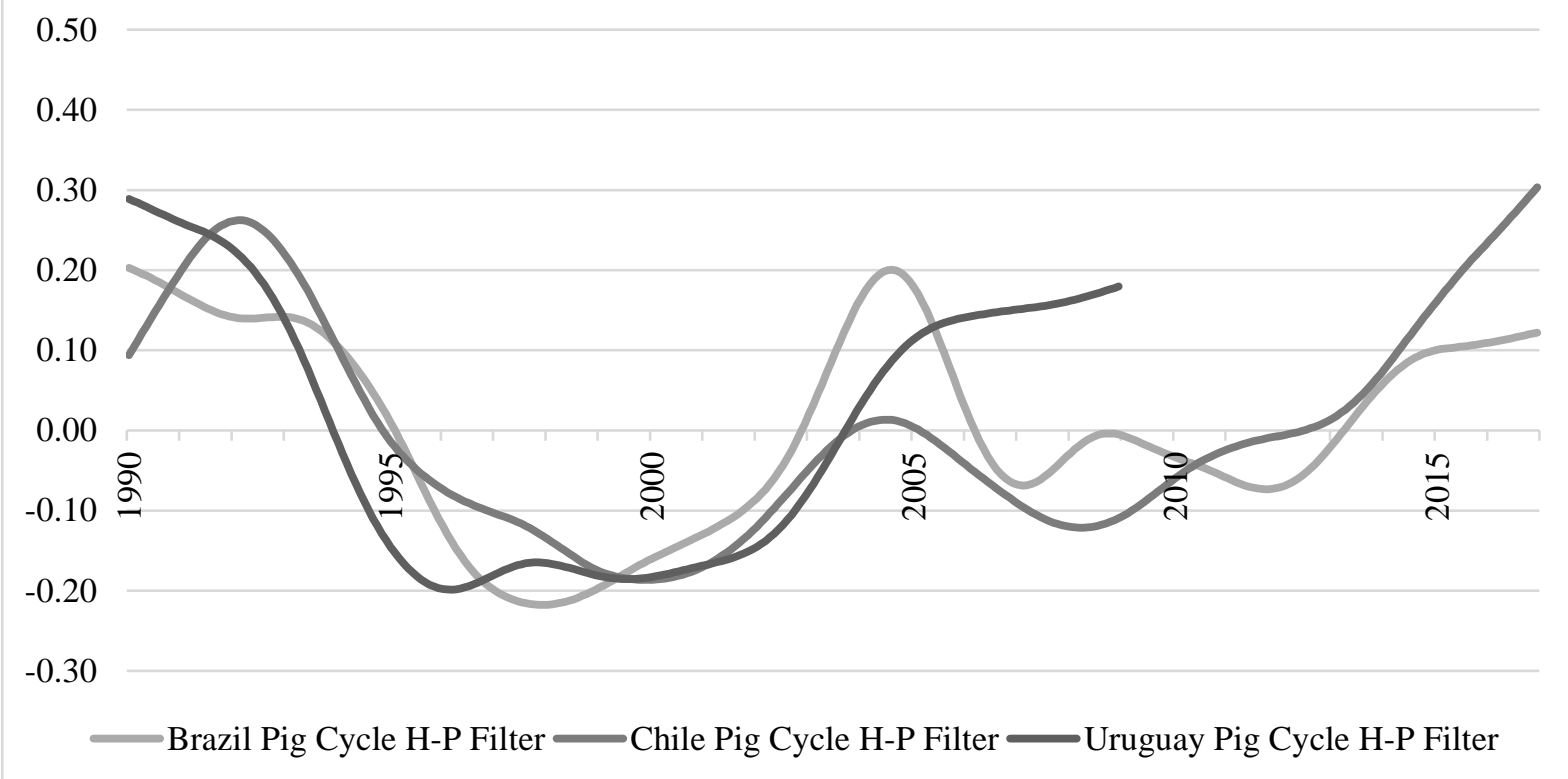

Figure A. 8 Hodrick-Prescott filter pig cycle in Brazil, Chile and Uruguay

Source: Authors. 


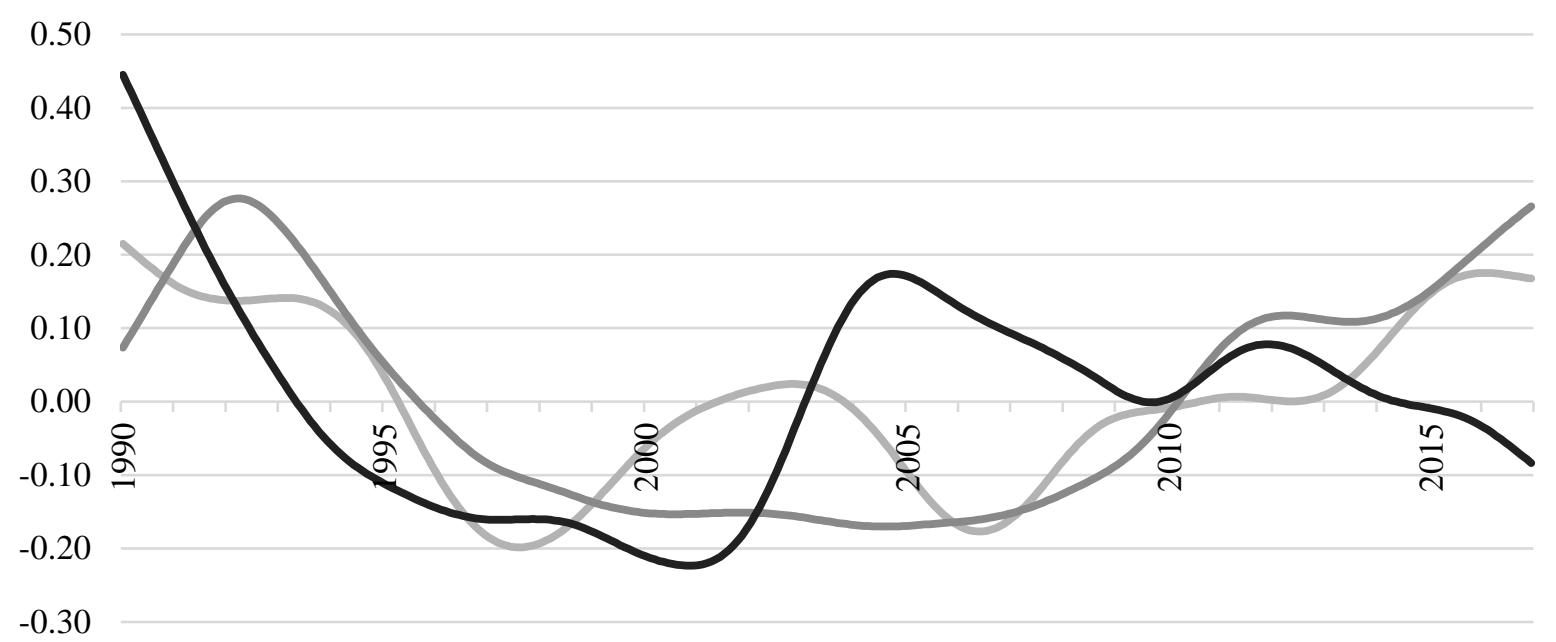

Brazil Cattle Cycle H-P Filter $\longrightarrow$ Chile Cattle Cycle H-P Filter —Uruguay Cattle Cycle H-P Filter

\section{Figure A. 9 Hodrick-Prescott filter cattle cycle in Brazil, Chile and Uruguay}

Source: Authors.

\section{A.6 Robustness test}

The bivariate concordance index calculated for the filtered cycles varies between 0.46 (Chile Cattle and Uruguay Cattle, calculated with the Hodrick-Prescott filter) and 0.74 (Chile Pig and Uruguay Pig, calculated with the Kalman filter), see Figure A.10. The interpretation of the concordance index for the aforementioned countries is that in $74 \%$ of the total observations, both cycles change synchronously in the same direction. As mentioned before, two series are perfectly procyclical, SPPS (countercyclical, SPNS), if the concordance index has a maximum value of unity (zero).

Resulting from our calculations, it is possible to say that the global concordance index calculated with the filtered cycles of the Hodrick-Prescott filter provides in six cases a higher concordance index. In three cases, the Kalman filter calculates higher ones. The bivariate global concordance index in the cattle sector is slightly higher between countries than in the pig sector.

It is visible that the bivariate global concordance index between pig and cattle in each country is higher than the calculated index between countries for the respective animal (livestock). It can be explained by the substitution effect demonstrated by Rivas et al., 1989; ODEPA, 2007; Farina and Rodriguez, 2013 and Bifaretti et al., 2014. Increases in income influence meat consumption patterns. Generally, consumers prefer cheaper protein sources that are affordable with lower incomes; with increasing incomes product preferences may change, as poorer households purchase cheaper meat such as chicken, while the more affluent prefer beef. When 
beef prices decrease, the demand in poorer households for beef increases, and decreases for chicken and pork.

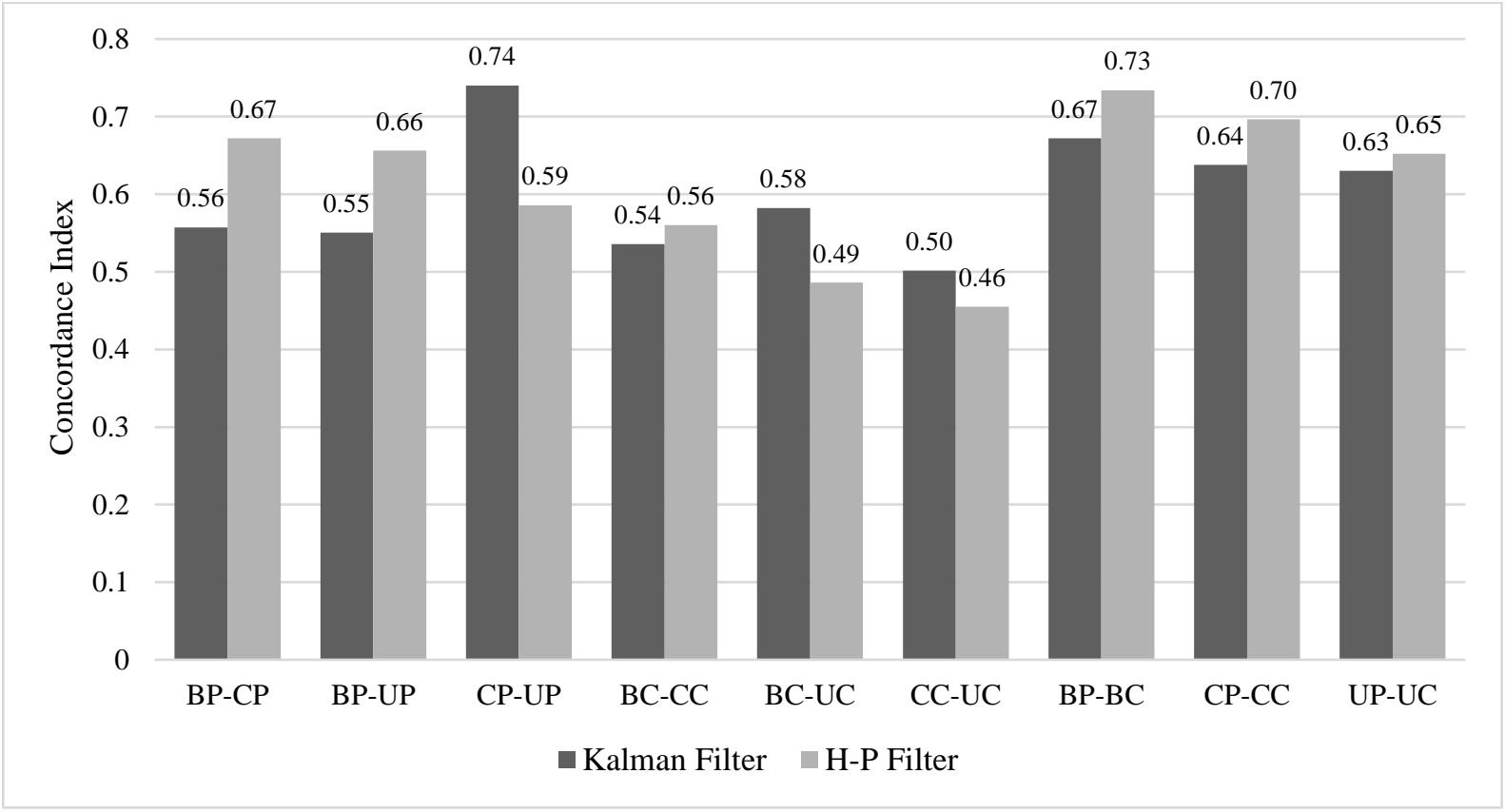

Figure A. 10 Bivariate global concordance index between countries calculated with the

\section{Kalman and Hodrick-Prescott filter}

Source: Authors.

The filtered cycles of the same country and product presents similar movements for the both filters, as seen in the Figure A.11 (I to VI).

The calculated bivariate global concordance index between the Kalman and Hodrick-Prescott filter in each country for the same product is between 0.71 for Brazil pig and 0.93 for Chile cattle. The high global concordance index between the filters of Chile cattle is observable in Figure A.11 (V) the cycles are very similar and prolonged.

The bivariate rolling concordance index takes values between 0.6 and 1 . At the end of all periods, the bivariate rolling concordance index between both filters decreases, with both cycles moving in the same direction. It is known that the Hodrick-Prescott filter has an unusual behaviour of cyclical components near the end of the period as mentioned by Baxter and King (1999) and Mise et al. (2005), therefore we use only the rolling concordance index obtained with cycles from the Kalman filter for the analysis of the bivariate rolling concordance index. 

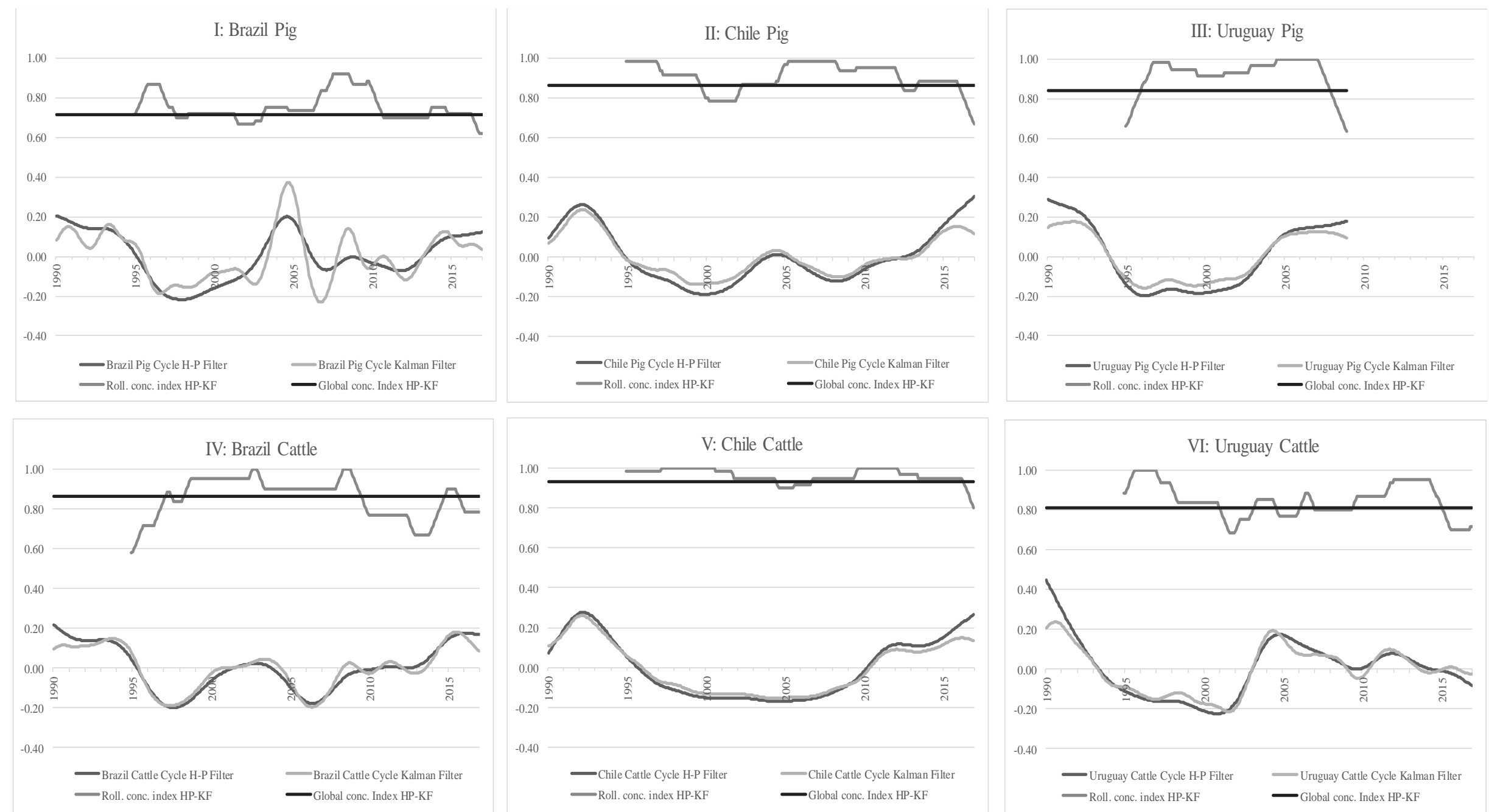

Figure A. 11 Global vs. Rolling window concordance index between Kalman and Hodrick-Prescott filter cycles for single commodities Source: Authors. 


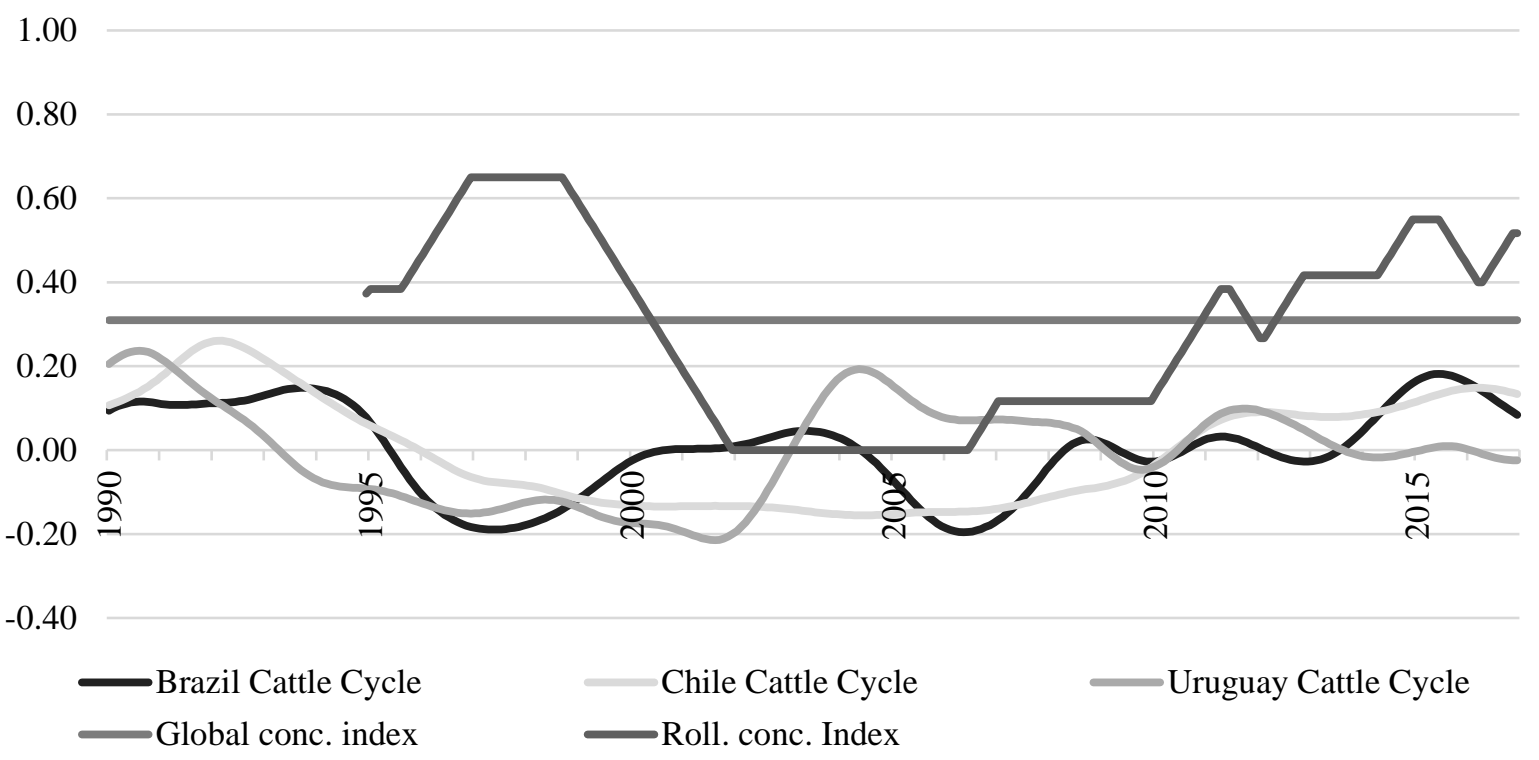

Figure A. 12 Rolling concordance index of the cycle components of all three cattle prices Source: Authors.

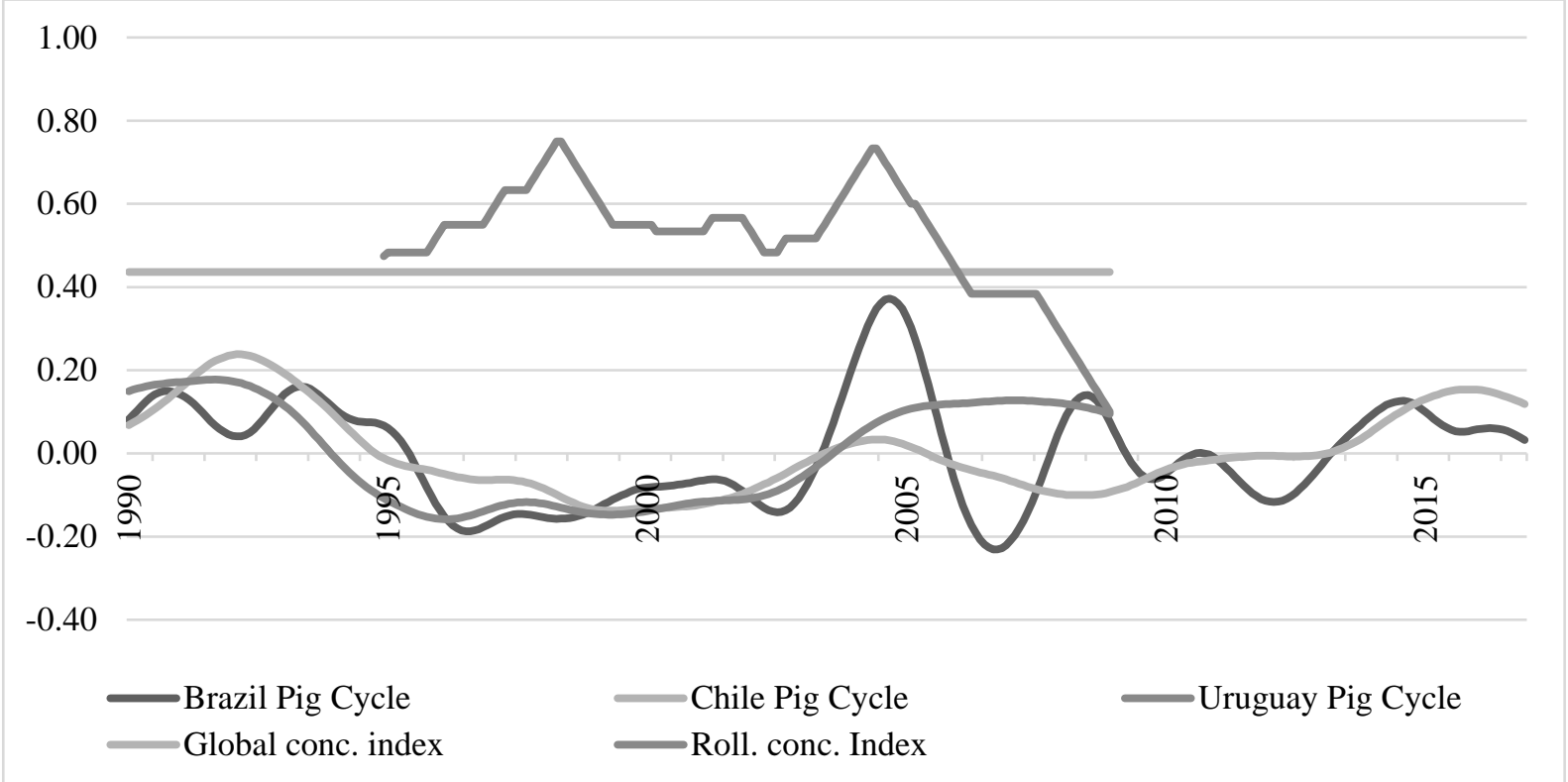

Figure A. 13 Rolling concordance index of the cycle components of all three pig prices Source: Authors. 
Table A. 10 Descriptive statistics of analysed producer prices for pig and cattle by country

\begin{tabular}{|c|c|c|c|c|c|c|}
\hline & \multicolumn{3}{|c|}{ Pig producer prices } & \multicolumn{3}{|c|}{ Cattle producer prices } \\
\hline & Brazil & Chile & Uruguay & Brazil & Chile & Uruguay \\
\hline $\begin{array}{l}\text { Start } \\
\text { month }\end{array}$ & 01.1990 & 01.1990 & 01.1990 & 01.1990 & 01.1990 & 01.1990 \\
\hline $\begin{array}{l}\text { Last } \\
\text { month }\end{array}$ & 12.2016 & 12.2016 & 12.2008 & 12.2016 & 12.2016 & 12.2016 \\
\hline $\begin{array}{l}\text { Number } \\
\text { of obs. }\end{array}$ & 324 & 324 & 228 & 324 & 324 & 324 \\
\hline Unit & $\mathrm{R} \$ / \mathrm{kg}$ & $\mathrm{Ch} \$ / \mathrm{kg}$ & $\mathrm{Ur} \$ / \mathrm{kg}$ & $\mathrm{R} \$ / \mathrm{kg}$ & $\mathrm{Ch} \$ / \mathrm{kg}$ & $\mathrm{Ur} \$ / \mathrm{kg}$ \\
\hline Mean & 1.0 & 469.9 & 12.5 & 2.7 & 572.5 & 12.0 \\
\hline Median & 0.9 & 450.7 & 11.8 & 2.6 & 567.5 & 12.3 \\
\hline Std. dev. & 0.2 & 110.5 & 2.9 & 0.6 & 102.8 & 2.5 \\
\hline Min. & 0.5 & 196.9 & 8.1 & 1.6 & 410.8 & 7.2 \\
\hline Max. & 1.8 & 847.8 & 21.4 & 4.1 & 878.6 & 18.5 \\
\hline $\mathrm{CV}$ & 0.3 & 0.2 & 0.2 & 0.2 & 0.2 & 0.2 \\
\hline
\end{tabular}

Source: Authors. 


\section{A.7 Hypothesis testing of synchronization stability}

\section{Table A. 11 Best model selected and stable or instable hypothesis testing}

\begin{tabular}{|c|c|c|c|c|c|c|c|c|c|c|c|c|c|c|c|c|c|}
\hline & $\begin{array}{l}\text { AIC } \\
\text { M2 }\end{array}$ & $\begin{array}{l}\text { AIC } \\
\text { M3 }\end{array}$ & $\begin{array}{l}\text { AIC } \\
\text { M4 }\end{array}$ & $\begin{array}{l}\text { Best } \\
\text { model }\end{array}$ & $\begin{array}{l}\mathrm{R}^{2} \\
\mathrm{M} 1\end{array}$ & $\begin{array}{l}\mathrm{R}^{2} \\
\mathrm{M} 2\end{array}$ & $\begin{array}{l}\mathrm{R}^{2} \\
\mathrm{M} 3\end{array}$ & $\begin{array}{l}\mathrm{R}^{2} \\
\mathrm{M} 4\end{array}$ & $\begin{array}{l}\text { \# rest- } \\
\text { rictions } \\
\mathrm{m}\end{array}$ & $\begin{array}{l}\text { \# pars } \\
\text { non } \\
\text { restr. } \\
\text { k }\end{array}$ & $\begin{array}{c}\# \\
\text { obs } \\
n\end{array}$ & $\begin{array}{l}\mathrm{R}^{2} \mathrm{nr}- \\
\mathrm{R}^{2} \mathrm{r}\end{array}$ & $1-R^{2} n r$ & $\mathrm{n}-\mathrm{k}$ & $\begin{array}{l}\text { F va- } \\
\text { lue }\end{array}$ & $\begin{array}{c}\text { F table } \\
(0.95 ; \\
\mathrm{m}, \mathrm{n}-\mathrm{k})\end{array}$ & decision \\
\hline BP-CP & -317.3 & -324.1 & -381.0 & M4 & 0 & 0.2 & 0.3 & 0.4 & 3 & 4 & 265 & 0.4 & 0.6 & 261 & 59.9 & 2.6 & $\begin{array}{c}\text { reject } \mathrm{H} 0: \\
\text { stable synchron. }\end{array}$ \\
\hline BC-CC & -218.5 & -369.4 & -399.7 & M4 & 0 & 0.0 & 0.5 & 0.5 & 3 & 4 & 265 & 0.5 & 0.5 & 261 & 93.2 & 2.6 & $\begin{array}{c}\text { reject } \mathrm{H} 0: \\
\text { stable synchron. }\end{array}$ \\
\hline BC-UC & -305.9 & -321.4 & -331.3 & M4 & 0 & 0.0 & 0.1 & 0.1 & 3 & 4 & 265 & 0.1 & 0.9 & 261 & 12.2 & 2.6 & $\begin{array}{c}\text { reject } \mathrm{H} 0: \\
\text { stable synchron. }\end{array}$ \\
\hline CC-UC & 47.5 & -258.7 & -313.5 & M4 & 0 & 0.1 & 0.7 & 0.8 & 3 & 4 & 265 & 0.8 & 0.2 & 261 & 288.8 & 2.6 & $\begin{array}{c}\text { reject } \mathrm{H} 0: \\
\text { stable synchron. }\end{array}$ \\
\hline CP-CC & 130.2 & -184.4 & -196.9 & M4 & 0 & 0.1 & 0.7 & 0.7 & 3 & 4 & 265 & 0.7 & 0.3 & 261 & 239.2 & 2.6 & $\begin{array}{c}\text { reject } \mathrm{H} 0: \\
\text { stable synchron. }\end{array}$ \\
\hline BP-UP & -287.1 & -393.2 & -395.5 & M4 & 0 & 0.4 & 0.7 & 0.7 & 3 & 4 & 265 & 0.7 & 0.3 & 165 & 123.6 & 2.7 & $\begin{array}{c}\text { reject } \mathrm{HO}: \\
\text { stable synchron. }\end{array}$ \\
\hline CP-UP & -183.6 & -261.4 & -399.4 & M4 & 0 & 0.3 & 0.6 & 0.8 & 3 & 4 & 265 & 0.8 & 0.2 & 165 & 231.3 & 2.7 & $\begin{array}{c}\text { reject } \mathrm{H} 0: \\
\text { stable synchron. }\end{array}$ \\
\hline BP-BC & -486.0 & -500.6 & -578.5 & M4 & 0 & 0.1 & 0.1 & 0.3 & 3 & 4 & 265 & 0.3 & 0.7 & 261 & 44.9 & 2.6 & $\begin{array}{c}\text { reject H0: } \\
\text { stable synchron. }\end{array}$ \\
\hline UP-UC & -244.9 & -368.5 & -367.3 & M3 & 0 & 0.4 & 0.7 & 0.7 & 2 & 3 & 265 & 0.7 & 0.3 & 166 & 198.6 & 3.1 & $\begin{array}{c}\text { reject } \mathrm{HO}: \\
\text { stable synchron. }\end{array}$ \\
\hline $\begin{array}{l}\text { BC- } \\
\text { CC-UC }\end{array}$ & -46.1 & -328.7 & -326.8 & M3 & 0 & 0.0 & 0.7 & 0.7 & 2 & 3 & 265 & 0.7 & 0.3 & 262 & 254.5 & 3.0 & $\begin{array}{c}\text { reject H0: } \\
\text { stable synchron. }\end{array}$ \\
\hline $\begin{array}{l}\text { BP-CP- } \\
\text { UP }\end{array}$ & -265.5 & -386.5 & -400.2 & M4 & 0 & 0.3 & 0.7 & 0.7 & 3 & 4 & 265 & 0.7 & 0.3 & 165 & 129.1 & 2.7 & $\begin{array}{c}\text { reject } \mathrm{H} 0: \\
\text { stable synchron. }\end{array}$ \\
\hline
\end{tabular}

Source: Authors. 


\section{Declaration on the own contribution to the work}

I hereby declare the contribution made to the chapters included in the dissertation:

The contents in chapter one and two are of my complete realization and have not been developed by other co-authors. The section Analytical framework was discussed with Prof. Dr. Rico Ihle at the beginning of the dissertation in order to have a good theoretical basis.

Chapter 3 "The pork and cattle sector in Brazil, Chile and Uruguay" is co-authored by Prof. Dr. Rico Ihle. The contributions of each author are as follows: Astrid Fliessbach and Prof. Dr. Rico Ihle conceptualized and designed the research. Astrid Fliessbach collected, analyzed and interpreted the data. Prof. Dr. Rico Ihle assisted in the analysis and interpretation of the results. Astrid Fliessbach wrote the paper. Prof. Dr. Rico Ihle provided valuable feedback at each stages of the chapter.

Chapter 4 "Pork and Cattle price cycle synchronization between Brazil, Chile and Uruguay" is co-authored by Prof. Dr. Rico Ihle. The contributions of each author are as follows: Astrid Fliessbach and Prof. Dr. Rico Ihle conceptualized and designed the research. Astrid Fliessbach collected, analyzed and interpreted the data. Prof. Dr. Rico Ihle assisted in the analysis and interpretation of the results. Astrid Fliessbach wrote the paper. Prof. Dr. Rico Ihle provided valuable feedback at each stages of the chapter.

The conclusion chapter is of my complete realization; the first part of this chapter summarizes chapter tree and four having these chapters Prof. Dr. Rico Ihle intellectual contribution. 


\section{Declaration}

1. I, hereby, declare that this dissertation has not been presented to any other examining body either in its present or a similar form. Furthermore, I also affirm that I have not applied for a Ph.D. at any other higher school of education.

Göttingen,

(Signature)

(Name in block capitals)

2. I, hereby, solemnly declare that this dissertation was undertaken independently and without any unauthorised aid.

Göttingen,

(Signature)

(Name in block capitals) 